\title{
MICRORNAS COMO BIOMARCADORES NO CARCINOMA \\ PAPILÍFERO DE TIREOIDE: ASSOCIAÇÃO COM \\ MUTAÇÕES SOMÁTICAS FREQUENTES E SIGNIFICADO \\ BIOLÓGICO
}

Dissertação apresentada ao Programa de PósGraduação Interunidades em Biotecnolgia USP/Instituto Butantan/IPT, para obtenção do Título do Mestre em Biotecnologia. 


\section{ANA CAROLINA BERNARDINI MOULATLET}

MicroRNAs como biomarcadores no carcinoma papilífero de tireoide: associação com mutações somáticas frequentes e significado biológico

$\begin{aligned} & \text { Dissertação } \\ & \text { Programa de }\end{aligned}$ Pós-Graduação
Interunidades
$\begin{aligned} & \text { USP/Instituto em } \\ & \text { Butantan/IPT, piotecnolgia } \\ & \text { obtenção do título de } \\ & \text { Biotecnologia }\end{aligned}$

Área de concentração: Biotecnologia

Orientadora: Profa. Dra. Patrícia Severino

Versão corrigida. A versão original eletrônica encontra-se disponível tanto na Biblioteca do ICB quanto na Biblioteca Digital de Teses e Dissertações da USP (BDTD). 
DADOS DE CATALOGAÇÃO NA PUBLICAÇÄO (CIP)

Serviço de Biblioteca e Informação Biomédica do

Instituto de Ciências Biomédicas da Universidade de Säo Paulo

reproduçäo näo autorizada pelo autor

Moulatlet, Ana Carolina Bernardini.

MicroRNAs como biomarcadores no carcinoma papilífero de tireóide: associação com mutações somáticas frequentes e significado biológico I Ana Carolina Bemardini Moulatlet. -- São Paulo, 2013.

Orientador: Profa. Dra. Patrícia Severino.

Dissertação (Mestrado) - Universidade de São Paulo. Instituto de Ciências Biomédicas. Programa de Pós-Graduação Interunidades em Biotecnologia USP/IPT/Instituto Butantan. Área de concentração: Biotecnologia. Linha de pesquisa: Marcadores moleculares em câncer.

Versão do título para o inglês: MicroRNAs as biomarkers in papillary thyroid cancer: association with frequent somatic mutations and biological significance.

1. Expressão gênica 2. Carcinoma papilífero de tireóide 3. MicroRNAs 4. BRAF 5. Material parafinado I. Severino, Profa. Dra. Patrícia II. Universidade de São Paulo. Instituto de Ciências Biomédicas. Programa de Pós-Graduação Interunidades em Biotecnologia USP/IPT/Instituto Butantan III. Título. 
Candidato(a):

Título da Dissertação:

Orientador(a):
Ana Carolina Bernardini Moulatlet.

MicroRNAs como biomarcadores no carcinoma papilífero de tireóide: associação com mutações somáticas frequentes e significado biológico.

Profa. Dra. Patrícia Severino.

\section{A Comissão Julgadora dos trabalhos de Defesa da Dissertação de Mestrado, em sessão pública realizada a I. ........... considerou
( ) Aprovado(a)
( ) Reprovado(a)

Examinador(a): Assinatura:

Nome:

Instituição:

Examinador(a): Assinatura:

Nome:

Instituição:

Presidente: Assinatura:

Nome:

Instituição: 
São Paulo, 06 de junho de 2008

Ref. CEP/Einstein $N^{\circ} 08 / 830$

CAAE - 0056.0.028.000-08

Título: IDENTIFICAÇÃO DE BIOMARCADORES EM NEOPLASIAS DE CABEÇA E PESCOÇO E TIREÓIDE ATRAVÉS DO ESTUDO DE mIRNAS ISOLADOS DE AMOSTRAS DE TECIDO PARAFINADO E FRESCO

Investigador Principal: Patrícia Severino

Ilma. Sra.

Patrícia Severino

O Comitê de Ética em Pesquisa do Hospital Israelita Albert Einstein analisou e aprovou o projeto de pesquisa supracitado, bem como isenção do Termo de Consentimento Livre e Esclarecido, do projeto de pesquisa supracitado.

Aproveitamos a oportunidade para orientar o pesquisador sobre os seguintes itens:

- O sujeito da pesquisa tem a liberdade de recusar-se a participar ou de retirar seu consentimento em qualquer fase da pesquisa, sem penalização alguma e sem prejuízo ao seu cuidado (Res. CNS 196/96 - Item IV.1.f) e deve receber uma cópia do Termo de Consentimento Livre Esclarecido, na íntegra, por ele assinado (Item IV.2d).

- O Pesquisador deve desenvolver a pesquisa conforme delineada no protocolo aprovado e descontinuar o estudo somente após análise das razões da descontinuidade pelo CEP que o aprovou (Res.CNS 196 Item III. 3z), aguardando seu parecer, exceto quando perceber risco ou dano não previsto

ao sujeito participante ou quando constatar a superioridade de regime oferecido a um dos grupos da pesquisa (Item V.3) que requeiram ação imediata. 
- O CEP deve ser informado de todos os efeitos adversos ou fatos relevantes que alterem o curso normal do estudo (Res. CNS Item V.4). É papel do pesquisador assegurar medidas imediatas adequadas frente a evento adverso grave ocorrido (mesmo que tenha sido em outro centro) e enviar notificação ao CEP e à Agência Nacional de Vigilância Sanitária - ANVISA - junto com seu posicionamento.

- Eventuais modificações ou emendas ao protocolo devem ser apresentadas ao CEP de forma clara e sucinta, identificando a parte do protocolo a ser modificada e suas justificativas. Em caso de projetos do Grupo I ou II apresentados anteriormente à ANVISA, o pesquisador ou patrocinador deve enviá-las também à mesma, junto com o parecer aprovatório do CEP, para serem juntadas ao protocolo inicial (Res. 251/97. item III.2.e).

- Relatórios parciais e finais devem ser apresentados ao CEP, inicialmente em Dezembro de 2008.

Atenciosamente,

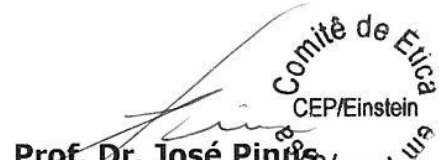

Coordenador do Comitê de Ética em Pesquisa

do Hospital Israelita Albert Einstein 
À Isabel, minha maior incentivadora. Mãe, obrigada por me dar todas as possibilidades de chegar onde hoje estou. Não é o fim, mas o começo.

À minha avó, que vivenciou pouco deste trabalho, mas me acompanhou em tantos outros. Um dia serei como você.

Ao meu irmão, pelas horas de desabafo.

Ao amor da minha vida. Zé, obrigada por todos os momentos que entendeu a minha ausência, e pelo apoio em todos os momentos. 


\section{AGRADECIMENTOS}

A todos que me ajudaram ao longo desta jornada, agradeço pela atenção e paciência; pelas diversas horas perdidas e pelos infindáveis emails que enviei em horas de desespero.

À minha orientadora Dra. Patrícia Severino, agradeço por me ensinar os caminhos da pesquisa. Obrigada pela oportunidade de desenvolver um trabalho tão interessante e instigante. Obrigada, também, pelas palavras e pelas horas de preocupação.

Ao Dr. Fábio Daumas Nunes da Faculdade de Odontologia (USP) pela colaboração e pelos ensinamentos de patologia.

Ao Juvani Lago e a Elisa da Faculdade de Odontologia (USP) por me ajudarem com os blocos de parafina. Levei um bom tempinho, mas estou quase conseguindo cortar de olhos fechados como vocês fazem.

Ao Laboratório de Biologia Molecular do HIAE por pelo suporte para a caracterização das mutações.

Às meninas do Laboratório de Biologia Molecular do HIAE por me acolherem tão bem. Obrigada em especial à Roberta Petroni, à Rúbia, à Jú e à Nair pelos sequenciamentos, e a Osíris por me ensinar a macro-dissecar as amostras.

Ao Juliano Jampietro, do Hospital ACCamargo, pelo tempo perdido com os diversos escaneamentos de lâmina.

À Dra. Edna Kimura e ao Dr. Júlio Ricarte-Filho do Instituto de Ciências Biológicas (USP) pelo auxílio com a caracterização das mutações.

Ao Dr. David Koperek do Departamento de Patologia Geral do Instituto de Patologia Ruprecht-Karls-University Heidelberg (Heidelberg, Alemanha) pela colaboração. 
A todos do CETEC pelo auxílio e atenção.

A todos do Centro de Ensino e Pesquisa do HIAE, agradeço pela companhia, amizade, palavras de descontração e incentivo. Foram momentos muito especiais. Obrigada Fê, Carlota, Martinha, Vâ, Lis, Rena, Papotto, Welbert, Camilinha, Andressa, Suzana, Eriquete, Eliana, Marilía, Alex, Jana, Jaila, Carina, Ivo, Deia, Luis, Rafael, Luciana, Claudina.

Ao nosso pequeno grupo, Flávia Maziero, Renata Machado Soares,Jean Parpineli e Dra. Adriana Sondermann por toda a ajuda que me deram, não só nos experimentos, nas nos momentos difíceis. Não teria sido a mesma coisa sem vocês. Obrigada pela amizade e pelas palavras de força.

À Dra. Adriana Sodermann por ter conseguido todas as amostras deste estudo, por ter auxiliado nas revisões de todos os casos e pelos ensinamentos sobre tireoide. Não tenho palavras pela ajuda.

À Dra. Marília Germanos pela revisão de todos os casos.

Ao Instituto de Ensino e Pesquisa Albert Einstein por disponibilizar sua estrutura para realização deste projeto e pelo suporte financeiro.

Ao CNPq pelo suporte financeiro, que possibilitou dedicação exclusiva para o desenvolvimento deste trabalho. 
"Que os vossos esforços desafiem as

impossibilidades, lembrai-vos de que as grandes coisas do homem foram conquistadas do que parecia impossível."

Charles Chaplin 


\section{RESUMO}

Moulatlet ACB. MicroRNAs como biomarcadores no carcinoma papilífero de tireoide: associação com mutações somáticas frequentes e significado biológico. [dissertação (Mestrado em Biotecnologia)]. São Paulo: Instituto de Ciências Biomédicas, Universidade de São Paulo; 2013.

Os microRNAs (miRNAs) constituem uma classe de pequenas moléculas de RNA não codificadoras de proteínas que ocorrem naturalmente em diversos organismos. Possuem grande importância na modulação da expressão gênica. Atualmente existem várias evidências sobre o papel de miRNAs na iniciação e na progressão de neoplasias, tornando-os ferramentas interessantes em prognóstico e/ou diagnóstico destas doenças. $O$ câncer de tireoide é um dos tipos mais comuns no sistema endócrino, sendo o carcinoma papilífero de tireoide (CPT) o responsável pela maior parte dos casos. Apesar de ter um bom prognóstico, uma porcentagem dos pacientes apresenta doença mais agressiva. Mutações somáticas ativam as vias MAPK e PI3K/AKT e parecem exercer papel importante no desenvolvimento dessa doença. Acredita-se que miRNAs regulem genes associados a essas vias e o estudo destas relações pode contribuir para uma melhor compreensão do seu significado biológico. Neste trabalho o perfil de expressão de miRNAs foi avaliado em amostras de CPT emblocadas em parafina caracterizadas quanto à presença da mutação BRAFV600E. Os resultados estão de acordo com a literatura quanto à utilização de material parafinado para análise da expressão de miRNAs, no entanto, ressaltam a importância da seleção cuidadosa da técnica para a detecção de mutações bem como o impacto da heterogeneidade dos tecidos emblocados sobre resultados de expressão gênica e detecção de mutações. Grande variabilidade na expressão de miRNAs foi observada entre os pacientes, fato importante quando se considera miRNAs como possíveis biomarcadores. Ensaios de microarranjos de DNA entre amostras positivas e negativas para mutação BRAFV600E mostraram diferenças na expressão dos miR-146b, miR-221 e miR-222, frequentemente associados ao CPT. Outros quatro miRNAs - miR146a, miR-21, miR-19a e miR-16 - envolvidos em processos e vias de sinalização semelhantes, também apresentaram expressão diferencial. Estes resultados ressaltam seu possível envolvimento na regulação de vias associadas a BRAF. Entretanto, quando os dados foram avaliados em amostras adicionais de CPT, apenas o miR-146b parece apresentar, de fato, expressão alterada entre estes dois grupos de amostras, ressaltando a variabilidade na expressão de miRNAs entre pacientes.

Palavras-chave: Carcinoma papilífero de tireoide. MicroRNAs. BRAF. Material parafinado. 


\begin{abstract}
Moulatlet ACB. MicroRNAs as biomarkers in papillary thyroid cancer: association with frequent somatic mutations and biological significance. [Masters thesis (Biotechnology)]. São Paulo: Instituto de Ciências Biomédicas, Universidade de São Paulo; 2013.

MicroRNAs (miRNAs) are evolutionaly-conserved, small non-coding RNA molecules fundamental in the regulation of protein-coding genes through sequence specific binding to messenger RNAs. Evidences suggest that miRNAs have a critical role in the initiation and progression of cancer, becoming interesting tools for diagnostic and prognostic purposes. Thyroid cancer is one of the most frequent neoplasias of the endocrine system and papillary thyroid cancer (PTC) accounts for most of the cases. Despite its good prognosis, patients may develop an aggressive disease that cannot be predicted using current diagnostic tests. Somatic mutations that activate MAPK and PI3K/AKT signaling pathways seem to play a leading role on the development of PTC. MiRNAs may contribute to the regulation of these pathways and, therefore, the study of this relationship helps in the understanding of their biological significance. We studied the expression profile of miRNAs in formalin-fixed, paraffin-embedded (FFPE) PTC samples submitted to mutation characterization. Our results corroborate literature reports on the applicatility of FFPE samples for miRNA expression profiling. However, results also highlight the importance of careful selection of mutation detection techniques and the impact of embedded sample heterogeneity on gene expression interpretation and mutation detection. Great variability was seen in miRNA expression among patients, an important issue when miRNA expression is evaluated as a prognostic or diagnostic marker. DNA microarray experiments comparing BRAFV600E positive and negative samples indicate that miR-146b, miR221 and miR-222, commonly reported as deregulated in PTC, might have differential expression depending on the mutation status of the tumor. Four other miRNAs miR146a, miR-21, miR-19a and miR-16 - were also deregulated indicating a possible implication in BRAF-related pathways. However, when additional samples were evaluated, only miR-146b presented consistent variation in expression, highlighting variability among patients.
\end{abstract}

Keywords: Papillary thyroid cancer. MicroRNAs. BRAF. FFPE tissue. 


\section{LISTA DE ILUSTRAÇÕES}

Figura 1: Biogênese e mecanismo de ação do miRNAs. Fonte: Inui et al., 2010.

Figura 2: Regulação das vias RAS/BRAF/MEK/ERK e PTEN/PI3K/AKT por miRNAs. Fonte: de la Chapelle, Jazdzewski, 2011.

Figura 3: Ilustração do resultado de sequenciamento para $B R A F^{V 600 E}$. A: eletroferograma de uma amostra positiva para a mutação $B R A F^{V 600 E}$ usada como controle. B: eletroferograma representativo de uma amostra negativa para a mutação $B R A F^{V G 00 E}$. C: eletroferograma representativo para uma amostra positiva para a mutação $B R A F^{V G 00 E}$. Setas indicam a localização da mutação puntual...........54

Figura 4: Avaliação da integridade do RNA total extraído de material parafinado de tireoide e de material fresco de uma linhagem celular (SCC25) através do ensaio Agilent RNA 6000 Pico chip no equipamento Bioanalyser. PT: tecido parafinado tumoral. L: padrão de peso molecular do kit Agilent RNA 6000 Pico chip. O material parafinado apresenta degradação do RNA (apenas um smear é visualizado após corrida), o que não foi observado para a linhagem celular (bandas 18S e $28 \mathrm{~S}$ claras e não há smear).

Figura 5: Avaliação das quantidades iniciais de RNA para análise de expressão gênica de miRNAs e eficiência dos primers (RNU44, RNU48, miR-146a, miR-146b, miR-221 e miR-222). Os diapositivos indicam eficiência próxima de $100 \%$ para todos os primers e valores entre 10ng e 50ng de RNA total inicial para a síntese de cDNA.

Figura 6: llustração do resultado de expressão do gene constitutivo RNU44 em 7 amostras de tireoide não macro-dissecadas. Baixa variação entre os valores de $\mathrm{Ct}$ médio entre as amostras indica expressão estável do controle endógeno

Figura 7: Histograma para a expressão do gene miR-146b em amostras pareadas congeladas e emblocadas em parafina. I: Média e desvio padrão dos valores de expressão normalizados para o gene miR-146b em amostras congeladas livres de tumor $(\mathrm{N})$, tumorais $(\mathrm{T})$ e amostras tumorais fixadas em parafina $(\mathrm{B})$. Uma diferença significativa foi observada entre $\mathrm{N}$ e $\mathrm{T}$, e entre $\mathrm{N}$ e $\mathrm{B}$, mas não entre $\mathrm{T}$ e $\mathrm{B}$. II: Expressão relativa expressa em fold change. Valor igual a 1 foi assumido para as amostras livres de tumor. Valores acima de 1,0 indicam maior expressão nas amostras tumorais congeladas $(\mathrm{T})$ e tumorais fixadas em parafina (B)....

Figura 8: Expressão relativa do miR-146b em 9 amostras de CPT comparadas com a expressão de uma amostra livre de tumor. Eixo $x$ indica cada um dos pacientes analisados. Eixo y apresenta a expressão relativa expressa em $\log _{2}$ do fold change. Valores acima de zero indicam maior expressão na amostra tumoral. $\mathrm{Na}$ vertical estão os valores correspondentes à porcentagem de células neoplásicas em cada uma das amostras. 
Figura 9: llustração do material utilizado para a extração de RNA. A: corte sem a coloração. Setas indicam as áreas raspadas. B: corte corado com H\&E. Áreas pontilhadas indicam a localização do tumor.

Figura 10: llustração do resultado de expressão do gene constitutivo RNU48 em amostras de tireoide macro-dissecadas (tumor e borda tumoral livre de tumor) após coloração com H\&E. Os valores de Ct médio obtidos se assemelham aos resultados obtidos para as mesmas amostras sem a coloração (não macro-dissecadas). .68

Figura 11: Expressão relativa do miR-146b em 5 amostras de CPT macrodissecadas comparada com a borda tumoral livre de tumor, de forma pareada. Com exceção do TIR54, o miR-146b mostrou-se mais expresso nas amostras de CPT. Eixo $x$ indica cada um dos pacientes analisados. Eixo $y$ apresenta a expressão relativa expressa em $\log _{2}$ do fold change. Valores acima de zero indicam maior expressão na amostra tumoral.

Figure 12: A: Amostra de CPT (TIR65) em diversos aumentos, mostrando a presença de infiltrados inflamatórios na região peritumoral. Da esquerda para a direita: imagem sem ampliação escaneada no Pannoramic 250 Flash II (3DHISTECH); barra de aumento correspondendo a $2000 \mu \mathrm{m}$; barra de aumento correspondendo a $200 \mu \mathrm{m}$. B: Expressão relativa do miR-146b em 3 amostras de CPT macro-dissecadas comparada com a borda tumoral livre de tumor, de forma pareada. As amostras apresentavam como condição associada inflitrados inflamatórios. Com exceção do TIR65, o miR-146b mostrou-se mais expresso nas amostras de CPT. Eixo x indica cada um dos pacientes analisados. Eixo y apresenta a expressão relativa expressa em $\log _{2}$ do fold change. Valores acima de zero indicam maior expressão na amostra tumoral. . .70

Figura 13: Histograma para a expressão do miR-146b em um painel de amostras de pacientes diagnosticados com carcinoma papilífero de tireoide. Valores de fold change foram obtidos comparando-se as amostras tumorais com o valor médio de expressão das amostras livres de tumor, de forma pareada. Eixo $x$ indica cada um dos pacientes analisados. Eixo $y$ apresenta a expressão relativa expressa em $\log _{2}$ do fold change. Valores acima de zero indicam maior expressão na amostra tumoral. $\mathrm{Na}$ vertical estão os valores correspondentes à porcentagem de células neoplásicas em cada uma das amostras.

Figura 14: Histograma para a expressão do miR-221 (A) e miR-222 (B) em um painel de amostras de pacientes diagnosticados com carcinoma papilífero de tireoide. Valores de fold change foram obtidos comparando-se as amostras tumorais com o valor médio de expressão das amostras livres de tumor, de forma pareada. Eixo $x$ indica cada um dos pacientes analisados. Eixo $y$ apresenta a expressão relativa expressa em $\log _{2}$ do fold change. Valores acima de zero indicam maior expressão na amostra tumoral. $\mathrm{Na}$ vertical estão os valores correspondentes à porcentagem de células neoplásicas em cada uma das amostras. 
Figura 15: Gel de agarose 2\% comparando as bandas formadas pelas amostras e pelo controle positivo (CP) - amostra de sangue de um paciente positivo para a mutação - após realizada uma PCR para amplificação da região de interesse do gene BRAF. Um marcador de massa molecular de $100 \mathrm{pb}$ (Invitrogen ${ }^{\mathrm{TM}}$ ) foi utilizado para avaliar o tamanho das bandas. As amostras 3 e 32 (pacientes TIR48 e TIR87, respectivamente) não amplificaram. CN: controle negativo.

Figura 16: Histograma para a expressão relativa do miR-146b (A), miR-221 (B) e miR-222 (C) em 39 amostras tumorais (CPT) comparadas com o valor médio de expressão de uma amostra de um paciente que passou por cirurgia para retirada de bócio. Eixo $x$ indica cada um dos pacientes analisados. Eixo $y$ apresenta a expressão relativa expressa em $\log _{2}$ do fold change. Valores acima de zero indicam maior expressão na amostra tumoral. Em cinza claro estão as amostras negativas para a mutação BRAFV600E. Em cinza escuro estão as amostras positivas para esta mutação. .80

Figura 17: Expressão relativa de miRNAs, representada em $\log _{2}$ do fold change, em amostras positivas e negativas para a mutação BRAF comparadas a uma amostra de bócio. (A) $\log _{2}$ do fold change para o miR-146b mostra diferença estatisticamente significativa de expressão entre amostras positivas e negativas para $\operatorname{BRAF}(p=0,013)$, (B) $\log _{2}$ do fold change para o miR-221 não mostra diferença estatisticamente significativa de expressão entre amostras positivas e negativas para $\operatorname{BRAF}(p=0,37)$ e (C) $\log _{2}$ do fold change para o miR-222 não mostra diferença estatisticamente significativa de expressão entre amostras positivas e negativas para $\operatorname{BRAF}(p=0,055)$. .83

Figura 18: Histograma mostrando o número de miRNAs detectáveis acima do valor de ruído de fundo para cada uma das amostras individulamente, de um total de 2084 miRNAs. .84

Figura 19: Histograma para a expressão relativa do miR-146a (A), miR-16 (B), miR21 (C) e miR-19a (D) em 39 amostras tumorais (CPT) comparadas com o valor médio de expressão de uma amostra de um apciente que passou por cirurgia para retirada de bócio. Eixo $x$ indica cada um dos pacientes analisados. Eixo $y$ apresenta a expressão relativa expressa em $\log _{2}$ do fold change. Valores acima de zero indicam maior expressão na amostra tumoral. Em cinza claro estão as amostras negativas para a mutação BRAFV600E. Em cinza escuro estão as amostras positivas para esta mutação.

Figura 20: Expressão relativa de miRNAs, representada em $\log _{2}$ do fold change, em amostras positivas e negativas para a mutação BRAF comparadas a uma amostra de bócio. Nenhum dos miRNAs apresentou diferença estatisticamente significativa entre amostras positivas e negativas para BRAF (A) miR-146a ( $p=$ $0,44)$, (B) miR-16 ( $p=0,94)$, (C) miR-19a $(p=0,38)$, (D) miR-21 ( $p=0,39)$.

Figura 21: Esquema de sinalização das vias de MAPK e PI3K/AKT, evidenciando a alteração BRAFV600E (X), e sua relação com miRNAs. Adaptado de la Chapelle, Jazdzewski, 2011 


\section{LISTA DE TABELAS}

Tabela 1: Mecanismos patogênicos, as características e o prognóstico de neoplasias de tireoide. Adaptada de Kondo et al., 2006.

Tabela 2: Mutações encontradas nas neoplasias de tireoide. Adaptada de Xing, 2013.

Tabela 3: Estudos envolvendo o perfil de expressão de microRNAs em carcinoma papilífero de tireoide. A tabela mostra uma lista de artigos publicados sobre a desregulação da expressão de microRNAs, evidenciando o tipo de amostra analisada, o método de análise empregado e os microRNAs encontrados superexpressos e pouco expressos neste tipo de tumor. Adaptada de Marini et al., 2011 e Lodewijk et al., 2012

Tabela 4: Características clínico-patológicas dos casos de CPT $(n=51)$ e de amostras livres de tumor $(n=2)$ incluídos neste estudo.

Tabela 5: Sequência madura e localização gênica dos miRNAs utilizados (Fonte: miRBase versão 20 - junho 2013 - http://www.mirbase.org/)

Tabela 6: Relação do pacientes selecionados para o ensaio de expressão global de miRNAs por microarranjos de DNA

Tabela 7: Características clínico-patológicas dos pacientes $(n=51)$ utilizados neste estudo.

Tabela 8: Características das amostras acessadas partir da técnica de morfometria

Tabela 9: Características das amostras de cada um dos 7 pacientes. Destacamos as condições associadas descritas no laudo anatomo-patológico.

Tabela 10: Caracterização dos pacientes quanto à mutação no gene $B R A F^{V 600 E} \mathrm{e}$ resultados da análise morfométrica

Tabela 11: Lista dos miRNAs encontrados mais expressos em amostras positivas para a mutação BRAFV600E comparadas a amostras negativas para a mutação, após análise de expressão global de miRNAs por microarranjos de DNA. .85

Tabela 12: MicroRNAs envolvidos nas vias de MAPK e PI3K/AKT .92 


\section{LISTA DE ABREVIATURAS E SIGLAS}

AGES Do inglês, age, grade, extent, size

AKT Do inglês, V-akt murine thymoma viral oncogene homolog

AMES Do inglês, age, distant metastases, extent, size

ATC Do inglês, anaplastic thyroid carcinoma

B-CPAP linhagem celular humana contendo mutação BRAFV600E

BRAF do inglês, Proto-oncogene B-Raf

ERK Do inglês, extracellular signal-regulated kinases

FTA Do inglês, follicular thyroid adenoma

FTC Do inglês, follicular thyroid carcinoma

HN Do inglês, hyperplasic nodules

MACIS Do inglês, metastasis, age, completeness of resection, invasion, and size

MAPK Do inglês, mitogen-activated protein kinase

MAPKK Do inglês, MAP/extracellular signal-regulated kinase - MEK

miRNA microRNA

MNG Do inglês, multinodular goiter

nt Nucleotídeos

NT Do inglês, normal thyroid tissue

$\mathrm{PCCl} 3$ Linhagem de tireoide de rato

PDTC Do inglês, poor differentiated thyroid carcinoma

PI3K Do inglês, phodphoinositide-3-kinase

pre-miRNA precursor do miRNA

CPT Carcinoma papilífero de tireoide

CPT-cv Variante clássica de CPT

CPT-fv Variante folicular de CPT

CPT-tc Variante de células altas de CPT

RAS Do inglês, v-Ki-ras2 Kirsten rat sarcoma viral oncogene homolog

RET/PTC Rearranjos envolvendo o oncogene RET

RISC Do inglês, RNA-induced silencing complex

RNAm RNA mensageiro

RTK receptor tirosina kinase

siRNA Do inglês, short interference RNA

T3 tiroxina

T4 tetraiodotironina

TNM Do inglês, tumor, node, metastasis

TPC-1 linhagem celular humana contendo rearranjo RET/PTC1 


\section{LISTA DE SÍMBOLOS}

$\begin{array}{ll}{ }^{\circ} \mathrm{C} & \text { Graus Celsius } \\ \mu \mathrm{g} & \text { Micrograma } \\ \mu \mathrm{l} & \text { Microlitro } \\ \mu \mathrm{M} & \text { Micro Molar } \\ \mathrm{g} & \text { Força centrifuga relativa } \\ \mathrm{min} & \text { Minutos } \\ \mathrm{mM} & \text { Milimolar } \\ \mathrm{ng} & \text { Nanograma } \\ \mathrm{pMol} & \text { Pico Mol } \\ \mathrm{s} & \text { Segundos } \\ \mathrm{U} & \text { Unidade enzimática }\end{array}$


1 INTRODUÇÃO

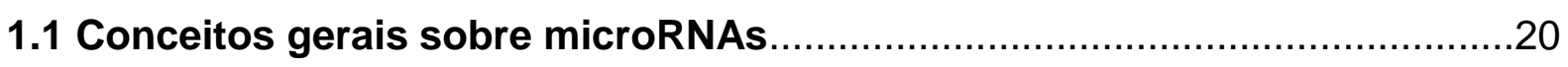

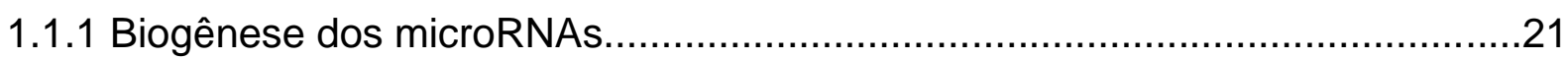

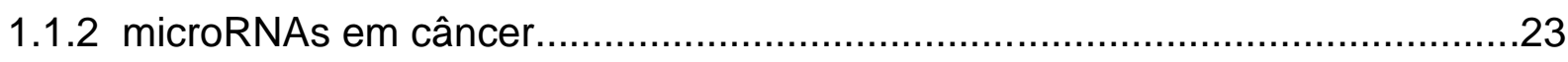

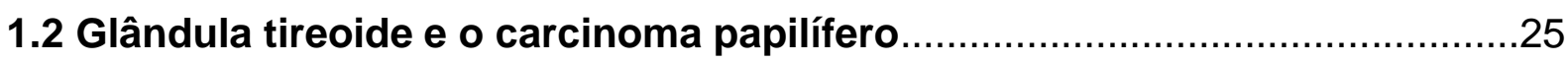

1.3 Carcinoma papilífero, mutações frequentes e vias de sinalização

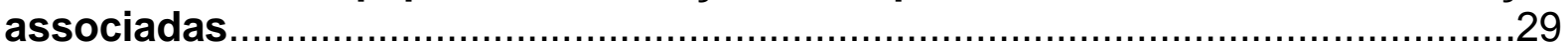

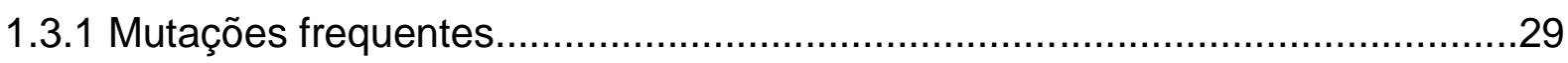

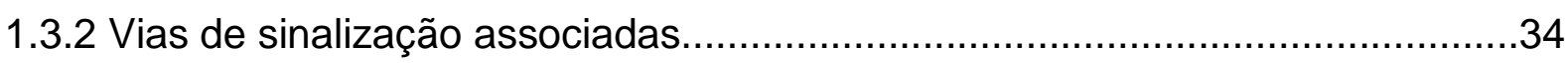

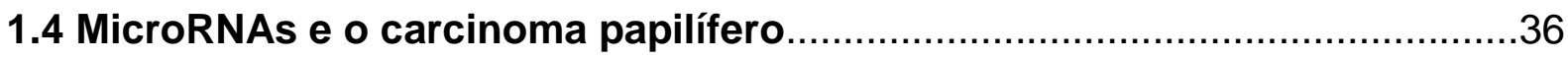

1.50 papel funcional de microRNAs em carcinoma papilífero.........................43

1.6 Identificação de microRNAs em amostras biológicas....................................44

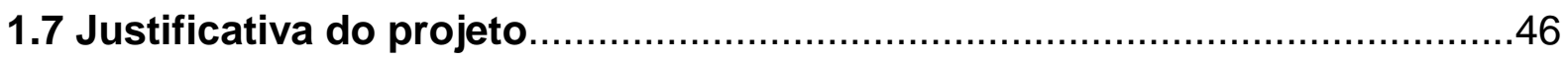

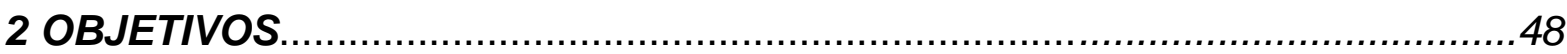

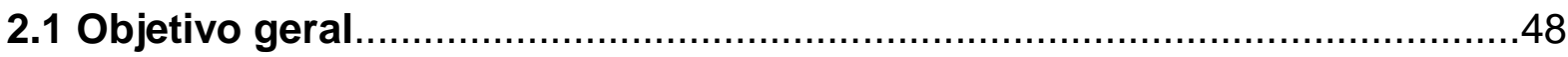

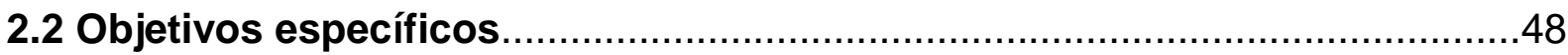

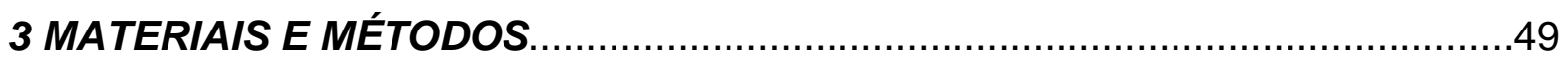

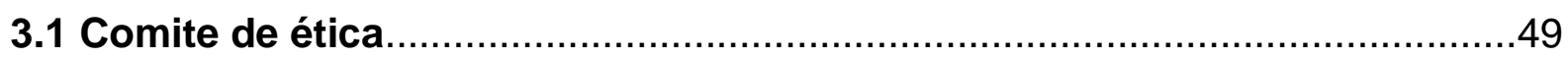

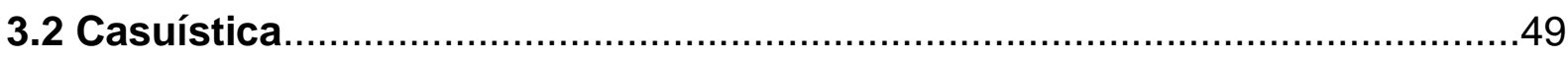

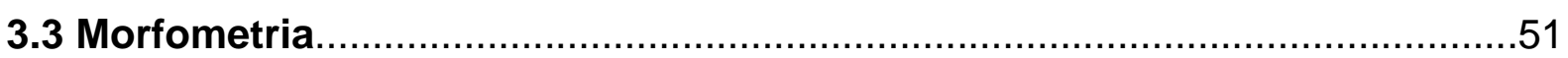

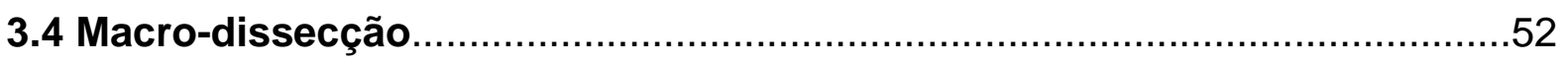

3.5 Extração de DNA e detecção da mutação $\mathrm{BRAF}^{\mathrm{V} 600 \mathrm{E}}$ e mutações nos códons $12 / 13$ e 61 do gene RAS por sequenciamento ............................................52

3.6 Deteç̧ão da mutação no gene BRAF ${ }^{\mathrm{V} 600 \mathrm{E}}$ por qRT-PCR …........................54

3.7 Detecção da mutação no gene $\mathrm{BRAF}^{\mathrm{V600}}$ por imuno-histoquímica .............55

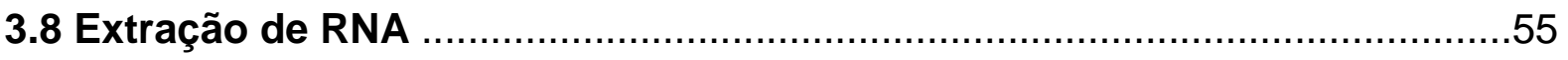

3.9 Quantificação e avaliação da qualidade e da integridade do RNA …............56 
3.10 Detecção do rearranjo RET/PTC por PCR em tempo real .56

3.11 Síntese de cDNA e PCR em tempo real para detecção de miRNAs .56

3.12 Avaliação da expressão global de miRNAs por microarranjos de DNA.

3.13 Análise estatística dos resultados de PCR em Tempo Real.......................58

4 RESULTADOS

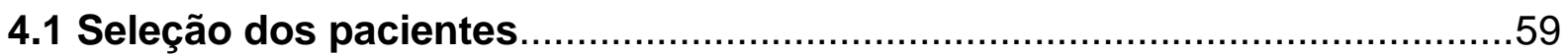

4.2 Características de amostras parafinadas e padronizações para análise de expressão gênica neste tipo de amostra........................................................60

4.3 Detecção de mutações frequentes em CPT: BRAF, RET-CPT, RAS.............74

4.3.1 Avaliação da qualidade do DNA extraído para fins de sequenciamento...........74

4.3.2 Detecção da mutação BRAF ${ }^{\mathrm{V} 600 \mathrm{E}}$ em amostras de CPT.................................75

4.3.3 Detecção da rearranjo RET/PTC em amostras de CPT ...................................78

4.3.4 Detecção de mutação em KRAS em amostras de CPT...................................78

4.4 Expressão de miRNAs em função das mutações frequentes.......................78

4.5 MiRNAs possivelmente associados à mutação BRAF $^{\mathrm{V} 600 \mathrm{E}}$ encontrados através da análise dos resultados de microarranjos de DNA e relação com vias

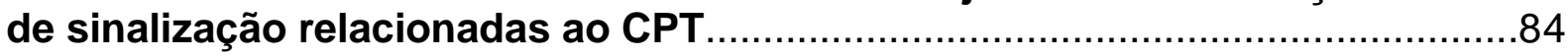

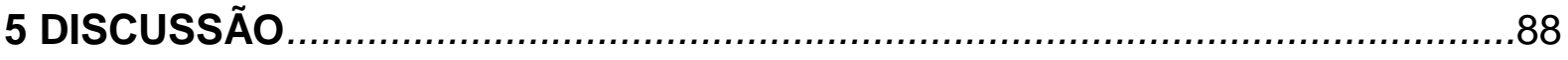

6 CONCLUSÕES

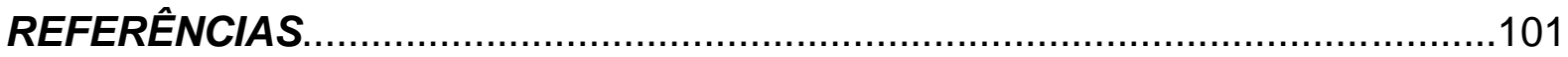

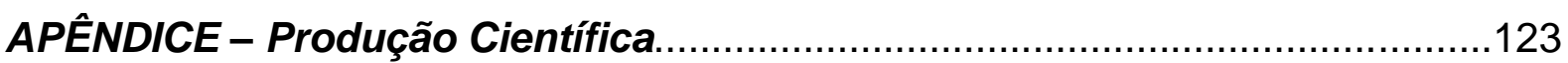




\section{INTRODUÇÃO}

\subsection{Conceitos gerais sobre microRNAs}

Durante as últimas décadas, diversos RNAs não codificadores de proteínas foram descritos como importantes reguladores de processos biológicos. Uma das classes que ganhou destaque foi a dos microRNAs (miRNAs). Os miRNAs são pequenas moléculas de RNA fita simples com 19-25 nucleotídeos (nt) de comprimento. Conservados durante a evolução, ocorrem naturalmente em diversos organismos, e apresentam grande importância na modulação fina da expressão gênica por regulação pós-transcricional (Mulero-Navarro et al., 2008). Tal modulação se dá quando essas pequenas moléculas se ligam seletivamente por pareamento de bases à região não traduzida (3'-UTR) de RNA mensageiros (RNAm), ditos RNAm alvos. O grau de complementariedade da ligação miRNA-mRNA determina se o RNAm alvo será degradado ou a tradução será inibida ou estimulada (Bhattacharyya et al., 2006; Doench et al., 2003; Hutvágner, Zamore, 2002; Liu et al., 2004; Vasudevan et al., 2007; Zeng et al., 2003). A complementariedade e especificidade de ligação ao RNAm alvo é mediada basicamente pelos nucleotídeos 2-8 da porção 5' do miRNA (denominados de "região ou sequência seed"). É essa sequência que se encontra conservada durante a evolução (Hutvágner, Zamore, 2002; Zeng et al., 2003).

Geralmente o RNAm é clivado quando a complementariedade é total. Ocorrendo mais comumente em plantas, o miRNA atua, neste caso, como um RNA de interferência (siRNA), quebrando o RNAm alvo (Llave et al., 2002; Yekta et al., 2004). Depois da quebra o miRNA está intacto e pode reconhecer e clivar outros RNAm alvos (Hutvagner, Zamore, 2002). Em animais, o pareamento geralmente é parcial e menos extenso, sendo menos frequente a clivagem. A presença de "mismatches" na região de ligação do duplex miRNA-mRNA (posições 10-12 da sequência madura do miRNA) é suficiente para impedir atuação do miRNA como siRNA, dando preferência à inibição da tradução.

A maioria dos miRNAs provoca uma redução modesta na concentração de seu RNAm alvo (menos de duas vezes) (Guo et al., 2010). Sob esse grau de inibição, grande parte das proteínas ainda se matêm ativa, e por isso o ajuste da expressão protéica é dito "modulação fina". Um único miRNA pode ter como alvo 
RNAm de genes distintos. Estima-se que essas pequenas moléculas regulem mais de um terço dos genes humanos (Ambros, 2003), e 60\% dos RNAm transcritos sejam alvos potenciais de miRNAs (Bentwich et al., 2005; Lim et al., 2005). Desta forma, os miRNAs exercem importante papel em processos fisiológicos distintos, incluindo simetria bilateral, resposta ao estresse, metabolismo, renovação, diferenciação, proliferação celular e apoptose (Ambros, 2003; Hwang et al., 2006).

\subsubsection{Biogênese dos microRNAs}

A biogênese dos miRNAs é um processo biogenético complexo envolvendo múltiplas proteínas. Pela via canônica, os genes de miRNAs são primeiro transcritos no núcleo pela RNA polimerase II (pol II), formando uma longa cadeia com 70-110 nt, conhecida como pri-miRNA, contendo unidas várias estruturas em formato de grampo (Borchert et al., 2006; Lee et al., 2002; Lee et al., 2004).

Os genes que codificam miRNAs são aparentemente induzidos e regulados por fatores de transcrição de uma maneira similar, se não idêntica, aos mRNAs convencionais (apesar de alguns genes que codificam miRNAs serem transcritos pela pol III). Estima-se que os genes de miRNAs representem $1 \%$ do genoma humano (Griffiths-Jones, 2004). Sua localização pode ser tanto intergênica, quanto dentro de íntrons de genes codificadores de proteína (miRtrons) (Krol et al., 2010). São encontrados como genes isolados, mas em algumas regiões estão agrupados, formando "clusters" de expressão conjunta.

Ainda no núcleo o pri-miRNA é processado pela endonuclease Drosha (uma RNase III) em conjunto com o cofator DGCR8 e uma helicase, para formar os precursores de miRNA (pre-miRNA). O pre-miRNA apresenta uma haste única com $\sim 11$ pb seguida por uma longa estrutura em formato de grampo com 60-70 nt de comprimento e 2 nt a mais na porção 3' terminal (Lee et al., 2002; Lee et al., 2003).

Uma vez formado, o pre-miRNA é exportado ativamente do núcleo para o citoplasma por um complexo chamado exportin-5/RanGTP (Bohnsack et al., 2004; Lund et al., 2004; Yi et al., 2003). No citoplasma, o pre-miRNA é processado por uma RNase III citoplasmática, a Dicer (Hutvagner et al., 2001), em conjunto os cofatores PACT e TRBP para retirar a alça e formar uma dupla fita contendo o par miRNA maduro e miRNA* (de tamanho similar) com 21-25 nt de comprimento. A dupla fita é, então, desenrolada por uma helicase (ainda não bem elucidada) e uma 
das fitas (miRNA maduro) é incorporada a um complexo ribonucleoproteico de silenciamento, conhecido como RISC (do inglês RNA-induced silencing complex). Qual das fitas será incorporada depende da estabilidade das bases na terminação 5' do duplex formado. A outra fita (miRNA*) é geralmente degradada (Lee et al., 2002; Tang, 2005).

Uma vez formado, o complexo se liga por complementariedade, que pode ser total ou parcial, na região não traduzida 3'UTR do RNAm alvo, levando à sua degradação ou impedindo a tradução. A tradução pode ser inibida tanto a nível inicial quanto a nível pós-inicial. A nível inicial, o complexo RISC interfere no reconhecimento da região cap do RNAm pelo fator elEF4F e no recrutamento da subunidade ribossomal 40S, ou interfere no acoplamento da subunidade 60S, impedindo a formação do complexo ribossomal 80S. A nível pós-inicial, RISC impede a elongação ribossomal, induzindo o desacoplamento do ribossomo ou facilitando a proteólise do peptídeo recém formado (Fabian et al., 2010) (Figura 1). 


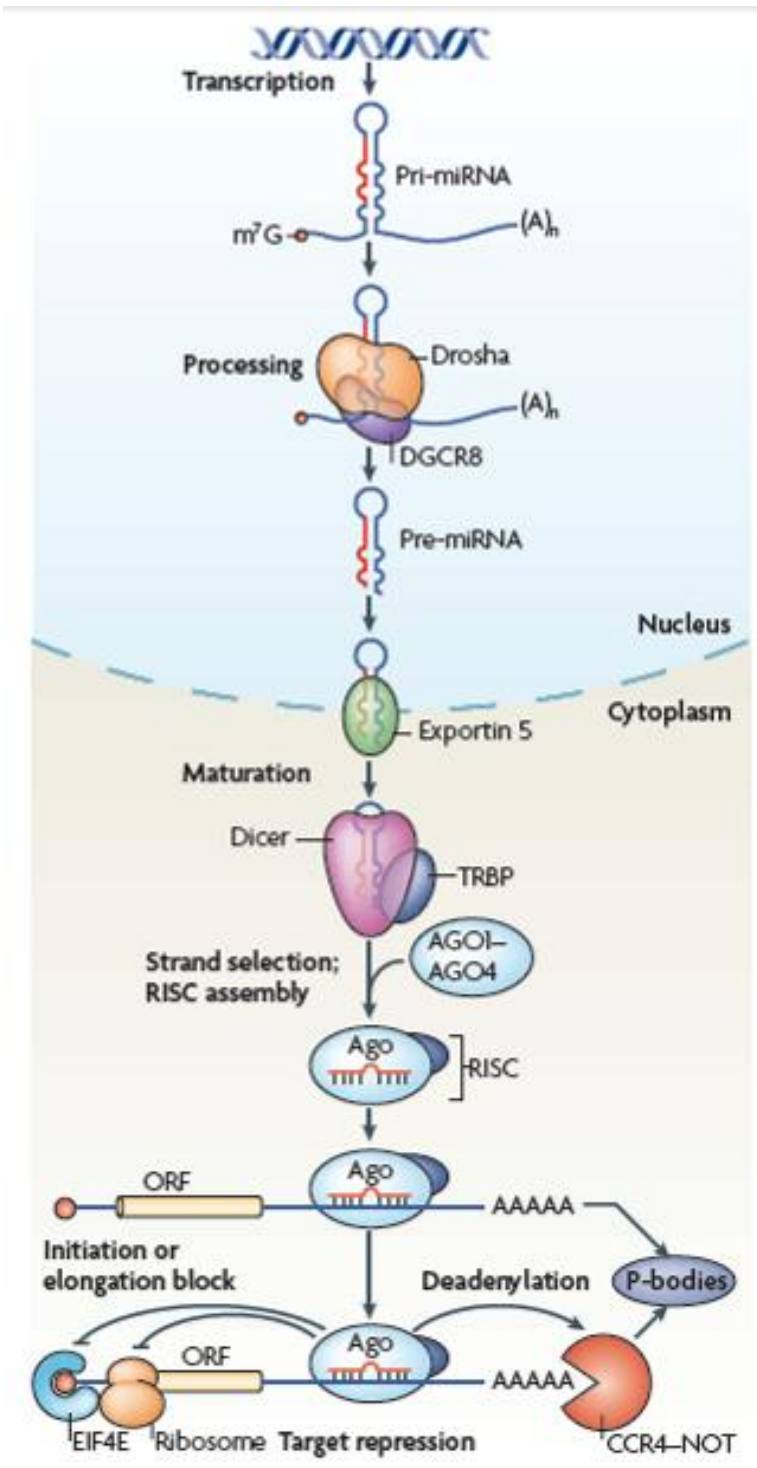

Figura 1: Biogênese e mecanismo de ação do miRNAs. Fonte: Inui, et al., 2010.

\subsection{2 microRNAs em câncer}

Os miRNAs são encontrados em múltiplos organismos e tipos celulares. Em humanos os genes que codificam miRNAs estão localizados em todos os cromossomos com exceção do cromossomo Y (Negrini et al., 2007), havendo 1872 sequencias de miRNAs humanos registrados na miRBase versão 19 (http://www.mirbase.org).

O primeiro miRNA foi identificado em 1993 durante pesquisas sobre desenvolvimento larval do nematodeo Caenorhabditis elegans (Lee et al., 1993). Denominado de lin-4, este miRNA ficou sendo o único conhecido de sua classe até o ano de 2000, quando o grupo de Reinhart identificou o segundo miRNA, o let-7, 
também em C. elegans (Reinhart et al., 2000). Em 2001 introduziu-se o termo miRNA para designar esta classe de RNAs de fita simples, não-codificantes (Lau et al., 2001; Lee, Ambros, 2001). A importância de miRNAs e câncer foi relatada alguns anos depois, quando o grupo de Calin (2005) observou deleção dos genes de miRNAs (miR-15 e miR-16) em leucemia linfocítica crônica, sugerindo que provavelmente mais de $50 \%$ dos genes de miRNAs estariam localizados em regiões genômicas associadas ao câncer (regiões encontradas deletadas ou amplificadas em tumores), em sítios frágeis ou em sítios de quebra (Calin et al., 2004).

Atualmente existem várias evidências sobre o papel de miRNAs na iniciação, desenvolvimento e progressão de neoplasias em diversos tecidos (Cho, 2007; Garzon et al., 2006; Yanaihara et al., 2006; Zhang et al., 2007), incluindo câncer coloretal (Michael et al., 2003); linfoma de células B (Eis et al., 2005); câncer de pulmão (Takamizawa et al., 2004); câncer de mama (lorio et al., 2005); gliobastoma (Chan et al., 2005; Ciafrè et al., 2005); e câncer de tireoide (He et al., 2005), entre outros.

A superexpressão de miRNAs específicos pode levar à repressão da expressão de genes supressores de tumor. Em contra partida, a baixa expressão de miRNAs pode resultar no aumento da expressão de oncogenes. Desta forma, alterações da expressão de miRNAs induzem proliferação celular, diferenciação e apoptose, levando ao crescimento e progressão do tumor.

Análises de expressão global de miRNAs em câncer mostraram diferentes perfis quando comparados tumores e tecidos normais (Calin, Croce, 2006). Na maioria dos tumores, os miRNAs apresentam menor expressão nos tecidos neoplásicos em comparação aos tecidos normais, independente do tipo celular. Além disso, tumores pouco diferenciados apresentam níveis de expressão global de miRNAs menores que tumores bem diferenciados ( $L u$ et al., 2005), apoiando a hipótese de que alta expressão global dessas pequenas moléculas está associada com a diferenciação celular. A redução da expressão diminuiria a diferenciação celular, que é uma das etapas fundamentais de desenvolvimento do câncer.

A avaliação do perfil global de expressão de miRNAs pode ser útil na classificação das neoplasias (Chuang, Jones, 2007; Lu et al., 2005), principalmente quando associado a características clínico-patológicas (Lu et al., 2005). Isso torna os miRNAs ferramentas moleculares possivelmente capazes de prever o prognóstico 
(Calin et al., 2005; Garzon et al., 2006), tendo grande potencial na prática clínica, inclusive em câncer de tireoide.

\subsection{Glândula tireoide e o carcinoma papilífero}

A tireoide é uma glândula endócrina constituída por dois lobos unidos por uma região chamada istmo, que dão formato de borboleta à glândula. Situada na região inferior do pescoço, a glândula tireoide é composta por dois tipos celulares distintos: as células foliculares $\mathrm{e}$ as células parafoliculares (ou do tipo $\mathrm{C}$ ), que são responsáveis, respetivamente, pela síntese e armazenamento dos hormônios tireoidianos tiroxina (T3) e tetraiodotironina (T4) (células foliculares), e de calcitonina (células $\mathrm{C}$ ), esta última importante na homeostase do cálcio. Alterações nessa glândula podem resultar em uma vasta gama de alterações patológicas, entre as mais comuns estão: hipotireoidismo, hipertireoidismo, nódulos tireoidianos, bócio, tireoidite e câncer. Alguns fatores demográficos, tais como, sexo, idade, excesso ou deficiência de iodo, exposição a raios $X$ ou radiações e histórico familiar parecem influenciar no aparecimento dessas doenças.

O câncer de tireoide é um dos tipos mais comuns de câncer do sistema endócrino. Sua taxa de incidência mundial aumentou nas últimas décadas (SEER http://seer.cancer.gov/statfacts/html/thyro.html\#incidence-mortality), sendo a maior entre todos os tipos de neoplasias (aumento de 6,6\%, entre 2000 e 2009 (SEER)). Nos Estados Unidos da America é responsável por $5 \%$ de todos os tipos de câncer que afetam as mulheres (Siegel et al., 2011), tendo incidência de 6,1 e 18,2 por 100.000 homens e mulheres, respectivamente (SEER). Em 2012 foram descritos 56.400 novos casos neste país (National Cancer Institute http://www.cancer.gov/cancertopics/types/thyroid). No Brasil foram descritos 10.590 novos casos de câncer da tireoide, com risco de 11 casos a cada 100 mil mulheres (INCA, 2012 - http://www.inca.gov.br/estimativa/2012), estando de acordo com a incidência anual mundial (140.000 novos casos, com cerca de 35.500 óbitos associados) (Ferlay et al., 2004).

O câncer de tireoide compreende um grupo de neoplasias heterogêneas com características clínicas e anatomopatológicas distintas, agrupadas em três categorias: carcinoma bem diferenciado (de origem celular folicular), carcinoma 
medular (derivado das células C) e carcinoma anaplásico ou indiferenciado. O carcinoma bem diferenciado é responsável por 94\% das neoplasias da glândula tireoide (Sherman, 2003). Neste grupo estão incluídos o carcinoma papilífero (CPT), o carcinoma folicular (FTC) e o carcinoma de células de Hürthle - uma variante do carcinoma folicular. A tabela 1 resume os mecanismos patogênicos, as características e o prognóstico destas neoplasias. 
Tabela 1: Mecanismos patogênicos, as características e o prognóstico de neoplasias de tireoide. Adaptada de Kondo et al., 2006.

\begin{tabular}{|c|c|c|c|c|c|c|c|c|}
\hline Tipo de tumor & Prevalência & $\begin{array}{c}\text { Proporção } \\
\text { mulher:homem }\end{array}$ & $\begin{array}{l}\text { Idade } \\
\text { (anos) }\end{array}$ & $\begin{array}{c}\text { Metástase } \\
\text { em } \\
\text { linfonodos }\end{array}$ & $\begin{array}{c}\text { Metástase } \\
\text { a } \\
\text { distância }\end{array}$ & $\begin{array}{l}\text { Taxa de } \\
\text { sobrevida } \\
\text { (em } 5 \\
\text { anos) }\end{array}$ & $\begin{array}{l}\text { Prognóstico e } \\
\text { procedimento }\end{array}$ & Características \\
\hline $\begin{array}{l}\text { Carcinoma } \\
\text { papilífero } \\
(\mathrm{CPT})\end{array}$ & $85-90 \%$ & $2: 1-4: 1$ & $20-50$ & $<50 \%$ & $5-7 \%$ & $>90 \%$ & $\begin{array}{l}\text { Tireodectomia } \\
\text { total e, em } \\
\text { alguns casos, } \\
\text { radioterapia } \\
\text { (novas drogas } \\
\text { em casos de } \\
\text { resistência); em } \\
\text { geral, bom } \\
\text { prognóstico. }\end{array}$ & $\begin{array}{l}\text { Bem diferenciado; com arquitetura } \\
\text { papilífera e caraterísticas nucleares que } \\
\text { incluem formato oval e alongado, } \\
\text { empilhamento dos núcleos, inclusões e } \\
\text { fendas; tendência a metástases em } \\
\text { linfonodos; sub classificado nas variantes } \\
\text { convencional, folicular e de células altas. }\end{array}$ \\
\hline $\begin{array}{l}\text { Carcinoma } \\
\text { folicular (FTC) }\end{array}$ & $<10 \%$ & $2: 1-3: 1$ & $40-60$ & $<5 \%$ & $20 \%$ & $>90 \%$ & $\begin{array}{l}\text { Tireodectomia } \\
\text { total e, } \\
\text { radiodoterapia } \\
\text { (novas drogas } \\
\text { em casos de } \\
\text { resistência); em } \\
\text { geral, bom } \\
\text { prognóstico. }\end{array}$ & $\begin{array}{l}\text { Bem diferenciado; hipercelular; com } \\
\text { padrões microfoliculares; ausência de } \\
\text { características nucleares observadas em } \\
\text { CPT; invasão vascular e/ou capsular } \\
\text { presentes; tendência a metástases via } \\
\text { corrente sanguínea. Apresenta como } \\
\text { subtipo o carcinoma de células de Hürthle, } \\
\text { responsável por 2-3\% dos tipos de câncer. } \\
\text { Caracterizado pela presença de células } \\
\text { grandes, células oncocíticas ricas em } \\
\text { mitocôndrias, núcleo e nucléolo densos; } \\
\text { maior propensão a metástases e pior } \\
\text { prognóstico. }\end{array}$ \\
\hline $\begin{array}{l}\text { Carcinoma } \\
\text { pouco } \\
\text { diferenciado }\end{array}$ & raro-7\% & $0,4: 1-2,1: 1$ & $50-60$ & $30-80 \%$ & $30-80 \%$ & $50 \%$ & $\begin{array}{l}\text { Cirurgia, } \\
\text { radioterapia (em } \\
\text { alguns casos), } \\
\text { quimioterapia, } \\
\text { radioterapia, } \\
\text { novas drogas; }\end{array}$ & $\begin{array}{l}\text { Pouco diferenciado; com características } \\
\text { semelhantes às de CPT e FTC; } \\
\text { agressividade considerada intermediária } \\
\text { entre carcinomas bem diferenciados e } \\
\text { pouco diferenciados. }\end{array}$ \\
\hline
\end{tabular}




\begin{tabular}{|c|c|c|c|c|c|c|c|c|}
\hline & & & & & & & $\begin{array}{l}\text { prognóstico } \\
\text { ruim. }\end{array}$ & \\
\hline $\begin{array}{l}\text { Carcinoma } \\
\text { indiferenciado } \\
\text { ou anaplásico }\end{array}$ & $2 \%$ & $1,5: 1$ & $60-80$ & $40 \%$ & $20-50 \%$ & $1-17 \%$ & $\begin{array}{l}\text { Cirurgia, } \\
\text { quimioterapia, } \\
\text { radioterapia, } \\
\text { novas drogas, } \\
\text { cuidados } \\
\text { paliativos. Alta } \\
\text { letalidade. }\end{array}$ & $\begin{array}{l}\text { Indiferenciado; contendo mistura de } \\
\text { células fusiformes, pleomórficas gigantes e } \\
\text { epitelióides; extremamente invasivo e } \\
\text { metastático; alta letalidade; pode ocorrer } \\
\text { de novo, derivar de CPT, FTC ou de } \\
\text { carcinoma pouco diferenciado. }\end{array}$ \\
\hline $\begin{array}{l}\text { Carcinoma } \\
\text { medular }\end{array}$ & $3 \%$ & $1: 1-1,2: 1$ & $30-60$ & $50 \%$ & $15 \%$ & $80 \%$ & $\begin{array}{l}\text { Cirurgia, } \\
\text { quimioterapia, } \\
\text { radioterapia, } \\
\text { novas drogas } \\
\text { (por exemplo, } \\
\text { vandetanib). }\end{array}$ & $\begin{array}{l}\text { Agressividade moderada; alta propensão a } \\
\text { metástases linfonodais; mutação em RET; } \\
\text { ocorrência familiar ou esporádica. }\end{array}$ \\
\hline $\begin{array}{l}\text { Carcinoma } \\
\text { medular com } \\
\text { presença de } \\
\text { carcinoma } \\
\text { folicular }\end{array}$ & raro & & & & & & & \\
\hline
\end{tabular}


O carcinoma papilífero é responsável por cerca de $85-90 \%$ dos casos de câncer de tireoide. Apesar de ser bastante estudado, pouco se sabe sobre o desenvolvimento e progressão desta neoplasia.

O carcinoma papilífero é composto de papilas, combinadas ou não a áreas foliculares, sem cápsula bem definida. Suas células contêm núcleos que aparentam estar empilhados, com fendas formadas por dobras na membrana nuclear e aparência típica em função do arranjo de sua cromatina, que lhes confere aspecto em vidro fosco e permite seu diagnóstico (Chan, Saw, 1986). A presença de corpos psamomatosos (estruturas calcificadas e laminadas) no estroma confirma seu diagnóstico (Batsakis et al., 1960). Frequentemente é multifocal e pode evoluir com metástases para linfonodos, especialmente cervicais. Metástases à distância também são observadas, e têm como sítios principais pulmão e ossos.

O carcinoma papilífero apresenta variantes e pode ser sub-classificado em clássico, folicular, células altas e difuso-esclerosante (Livolsi, 1992; Robbins et al., 1991; Rosai et al., 1993). A variante de células altas ocorre com maior frequência em pacientes idosos e do sexo masculino, que geralmente presentam pior prognóstico, merecendo tratamento agressivo. Já a variante difuso-esclerosante é caracterizada pela aparência histológica distinta e envolvimento difuso da glândula tireoide associado a metástases regionais e à distância, principalmente nos pulmões (Carcangiu, Bianchi, 1986). Ocorre em crianças e adultos jovens, sendo mais comum em mulheres.

Na prática clínica, os métodos diagnósticos disponíveis para a detecção do CPT ainda não são capazes de determinar o prognóstico dos portadores desta doença. Os sistemas de classificação e estadiamento do carcinoma de tireoide TNM (Sobin, Wittekind, 2009), AMES (Cady, Rossi, 1988), AGES (Hay et al., 1987), MACIS (Hay et al., 1993), desenvolvidos com a intenção de predizer sobrevida e prognóstico, também são falhos, evidenciando a necessidade de maiores estudos.

\subsection{Carcinoma papilífero, mutações frequentes e vias de sinalização associadas}

\subsubsection{Mutações frequentes}


Diversas alterações gênicas já foram descritas em neoplasias de tireoide. Especialmente em CPT a alteração mais comumente encontrada é a mutação no gene BRAF (BRAF ${ }^{\mathrm{V} 600 \mathrm{E}}$ ), ocorrendo em $29-83 \%$ dos casos de CPTs (Ricarte-Filho et al., 2009; Riesco-Eizaguirre, Santisteban, 2007; Xing, 2005). A variabilidade da presença da mutação pode se dar devido à sensibilidade dos diferentes métodos de detecção. Tumores apresentam, tipicamente, alelos normais e alelos mutados (contendo mutação $\mathrm{BRAF}^{\mathrm{V} 600 \mathrm{E}}$ ) distribuídos de forma heterogênea pela região tumoral (Guerra et al., 2012; Milbury et al., 2009). O alelo normal pode exceder vastamente a quantidade do alelo mutante, tornando difícil a deteç̧ão e identificação dos alelos minoritários presentes em baixas concentrações. Dependendo da técnica utilizada, a sensibilidade e a especificidade podem variar, impedindo a deteç̧ão da mutação quando a população de células com o alelo mutado for muito baixa (Lee et al., 2012; Jin et al., 2006; Kim et al., 2008; Vogelstein; Kinzler, 1999). Os métodos podem ser mais ou menos trabalhosos e dispendiosos, além de complicados, por exemplo, quando o DNA é pouco preservado (material parafinado) ou há presença de grande quantidade de tecido não tumoral na amostra (Kim et al., 2008; Kim et al., 2011).

Recentemente foram desenvolvidos dois métodos com alta sensibilidade e especificidade: (a) anticorpo específico para a mutação em BRAF, que permite a visualização por imunohistoquímica da proteína BRAF ${ }^{\mathrm{V} 600 \mathrm{E}}$ (Capper et al., 2011; Capper et al., 2012; Koperek et al., 2012), e (b) PCR em tempo real. Na técnica de imunohistoquimica, a proveniência do material (fresco ou emblocado em parafina; menor ou maior degradação da molécula de DNA, respectivamente) não influencia nos resultados. Além disso, é capaz de detectar pequenas porções de células mutadas envoltas por tecido não neoplásico, como nos microcarcinomas. A técnica de PCR em tempo real é capaz de detectar alelos mutados com porcentagens de até $2 \%$ no tecido, sendo ideal para amostras com baixa pureza tumoral. A sensibilidade é bastante alta quando a porcentagem de alelos mutados é maior que $10 \%$.

O gene BRAF está localizado no cromossomo 7q24 e codifica uma quinase serina-treonina, que sofre fosforilação após ativação de RAS. Quando mutada resulta da troca de uma timina por uma adenina $(T>A)$ na posição 1799. Em consequência, uma valina é substituída por um glutamato na posição 600 da 
proteína. O sítio de fosforilação T599/S602 é mimetizado e a proteína torna-se constitutivamente ativa (Wellbrock et al., 2004).

Evidências experimentais mostram que esta mutação está relacionada com extensão extra-tireoidal, metástase em linfonodo, estágios avançados da doença e propensão à re-operação cervical, indicando maior agressividade da doença (Elisei et al., 2008; Kim et al., 2012; Lupi et al., 2007; Xing et al., 2005; Xing et al., 2007; Yip et al., 2009). No entanto, associação entre a presença da mutação e fatores clínicopatológicos e menor expectativa de vida não foi confirmada por outros grupos, evidenciando que os resultados são preliminares e ainda controversos (Fugazzola et al., 2004; Fugazzola et al., 2006; Ito et al., 2009; Kim et al., 2005; Liu et al., 2005; Sapio et al., 2007a, b; Yip et al., 2011). A discordância dos resultados pode, em parte, estar relacionada a diferenças regionais (Lima et al., 2004; Nikiforova et al., 2004; Xing, 2005).

A presença da mutação também parece estar relacionada a características histológicas do tumor, ocorrendo com maior frequência nos subtipos clássico oncocítico e de células altas (Koperek et al., 2012; Nikiforova et al., 2003; Trovisco et al., 2005; Xing, 2005), e com menor prevalência ou ausente no subtipo com padrão exclusivamente folicular (Koperek et al., 2012; Nikiforova et al., 2003; Xing, 2005). No entanto, ocorre em microcarcinomas com este padrão, sugerindo que o padrão folicular é alterado a padrão clássico durante o desenvolvimento do tumor (Koperek et al., 2012).

Além da mutação BRAF ${ }^{\mathrm{V} 600 \mathrm{E}}$, alterações no gene RET e no gene RAS também são observadas em CPT. No entanto, ocorrem com menor frequência (Tabela 2). 
Tabela 2: Mutações encontradas nas neoplasias de tireoide. Adaptada de Xing, 2013.

\begin{tabular}{|c|c|c|c|c|}
\hline Mutação & Tipo de tumor & $\begin{array}{c}\text { Incidência } \\
\text { aproximada (\%) }\end{array}$ & $\begin{array}{c}\text { Vias de } \\
\text { sinalização } \\
\text { alteradas }\end{array}$ & Impacto funcional \\
\hline \multirow{4}{*}{ BRAFV600E } & CPT-cV & 45 & \multirow{4}{*}{ MAPK } & \multirow{4}{*}{$\begin{array}{l}\text { Ativadora; promove } \\
\text { tumorigênese, invasão, } \\
\text { metástase, recorrência e } \\
\text { morte. }\end{array}$} \\
\hline & CPT-fV & 15 & & \\
\hline & CPT-tc & $80-100$ & & \\
\hline & ATC & 25 & & \\
\hline BRAFK601E & CPT-fv & 5 & MAPK & $\begin{array}{l}\text { Ativadora; provavelmente } \\
\text { similar a BRAFV600E. }\end{array}$ \\
\hline \multirow{5}{*}{$\begin{array}{l}\text { HRAS, KRAS, } \\
\quad \text { NRAS }\end{array}$} & FTA & $20-25$ & \multirow{5}{*}{$\begin{array}{l}\text { MAPK e PI3K- } \\
\text { AKT }\end{array}$} & \multirow{6}{*}{$\begin{array}{l}\text { Ativadora; promove } \\
\text { tumorigênese, invasão, } \\
\text { metástase em PDTC e FTC. }\end{array}$} \\
\hline & FTC & $30-45$ & & \\
\hline & CPT-fv & $30-45$ & & \\
\hline & PDTC & $20-40$ & & \\
\hline & ATC & $20-30$ & & \\
\hline \multirow{4}{*}{$\begin{array}{c}\text { PTEN } \\
\text { (mutação) }\end{array}$} & FTA & 0 & \multirow{4}{*}{$\mathrm{PI} 3 \mathrm{~K}-\mathrm{AKT}$} & \\
\hline & FTC & $10-15$ & & \multirow{3}{*}{$\begin{array}{l}\text { Inativa o gene, mas ativa a } \\
\text { via de PI3K; promove } \\
\text { tumorigênese e invasão. }\end{array}$} \\
\hline & ATC & $10-20$ & & \\
\hline & СРТ & $1-2$ & & \\
\hline $\begin{array}{c}\text { PTEN } \\
\text { (deleção) }\end{array}$ & FTC & 30 & PI3K-AKT & $\begin{array}{l}\text { Inativa o gene, mas ativa a } \\
\text { via de PI3K; promove } \\
\text { tumorigênese e invasão. }\end{array}$ \\
\hline \multirow{4}{*}{ PIKЗCA } & FTA & $0-5$ & \multirow{4}{*}{ PI3K-AKT } & \multirow{4}{*}{$\begin{array}{l}\text { Ativadora; promove } \\
\text { tumorigênese e invasão. }\end{array}$} \\
\hline & FTC & $5-15$ & & \\
\hline & ATC & $15-25$ & & \\
\hline & СРТ & $1-2$ & & \\
\hline$A K T 1$ & $\begin{array}{l}\text { Carcinoma } \\
\text { metastático }\end{array}$ & 15 & PI3K-AKT & $\begin{array}{l}\text { Inconclusivo; parece ser } \\
\text { favorável a ocorrência de } \\
\text { metástase. }\end{array}$ \\
\hline \multirow{2}{*}{ CTNNB1 } & PDTC & 25 & \multirow{2}{*}{ WNT- $\beta$-catenin } & \multirow{2}{*}{$\begin{array}{l}\text { Ativadora; promove } \\
\text { progressão tumoral. }\end{array}$} \\
\hline & ATC & $60-65$ & & \\
\hline \multirow{2}{*}{ TP53 } & PDTC & 25 & \multirow{3}{*}{$\begin{array}{l}\text { p53-coupled } \\
\text { pathways }\end{array}$} & \multirow{2}{*}{$\begin{array}{l}\text { Inativadora; promove } \\
\text { progressão tumoral. }\end{array}$} \\
\hline & ATC & $70-80$ & & \\
\hline \multirow{4}{*}{$I D H 1$} & FTC & $5-25$ & & \multirow{4}{*}{$\begin{array}{l}\text { Inativadora; impacto no tumo } \\
\text { ainda não está claro. }\end{array}$} \\
\hline & CPT-fv & 20 & \multirow{3}{*}{$\begin{array}{l}\text { IDH1-associated } \\
\text { metabolic } \\
\text { pathways }\end{array}$} & \\
\hline & ССРТ & 10 & & \\
\hline & ATC & $10-30$ & & \\
\hline$A L K$ & ATC & 10 & $\begin{array}{l}\text { MAPK e PI3K- } \\
\text { AKT }\end{array}$ & $\begin{array}{l}\text { Ativadora; provavelmente } \\
\text { promove progressão tumoral. }\end{array}$ \\
\hline$E G F R$ & ССРT & 5 & $\begin{array}{l}\text { MAPK e PI3K- } \\
\text { AKT }\end{array}$ & $\begin{array}{l}\text { Ativadora; impacto no tumor } \\
\text { ainda não está claro. }\end{array}$ \\
\hline RET/PTC & СРТ & $0-86$ & $\begin{array}{l}\text { MAPK e PI3K- } \\
\text { AKT }\end{array}$ & $\begin{array}{l}\text { Ativadora; promove } \\
\text { tumorigênese. }\end{array}$ \\
\hline
\end{tabular}


Em CPT, as mutações no gene RET envolvem rearranjos denominados de RET/PTC. Estão descritos pelo menos 10 tipos de variantes de RET/PTC, todos apresentando fusão do domínio tirosina quinase do gene RET com outros genes, resultando no ganho de uma região promotora e uma região 5' codificante (Santoro et al., 2006). Entre todas as variantes, a RET/PTC1 (uma inversão [inv (10) (q11.2q21)] - fusão do domínio tirosina quinase (TK) de RET com a região 5' terminal de um gene H4 ou CCDC6) e a RET/PTC3 (fusão do domínio TK do gene RET com o gene RFG (ou Ele1/ARA70/Ncoa4) (Santoro et al., 1994)) são as que ocorrem com maior frequência.

A incidência de RET/PTC nesse tipo de tumor varia entre 0 e 87\% (Marotta et al., 2011; Santoro et al., 1992; Zhu et al., 2006). Tais observações podem, em parte, estar relacionadas à variabilidade geográfica, mas não servem como explicação única (Zhu et al., 2006). As inversões paracêntricas na região 10q11.2 não são, no entanto, detectadas citogeneticamente (Santoro et al., 2006), dificultando sua identificação. Além disso, a PCR convencional de regiões do DNA genômico também não é adequada para a detecção, pois os rearranjos ocorrem imediatamente a frente do gene do domínio tirosina quinase, enquanto o gene fusionado é truncado em diferentes pontos do tumor. Consequentemente, longas sequências intrônicas separam os éxons dos genes, sendo inviável a detecção por sequenciamento (Salvatore et al., 2000; Sugg et al., 1998; Xu et al., 2003)

Não obstante, a distribuição do rearranjo RET/PTC é ainda bastante heterogênea dentro do tumor, podendo envolver quase todas as células neoplásicas (RET/PTC clonal), ou ser detectado apenas em uma pequena fração de células tumorais (RET/PTC não clonal) (Unger et al., 2004; Zhu et al., 2006). Tumores com RET/PTC não clonal frequentemente apresentam outras alterações genéticas, não respondendo aos inibidores de RET da mesma forma que tumores com o rearranjo clonal (Nikiforov et al., 2008).

Em geral, a prevalência de RET/PTC é maior em pacientes jovens ou expostos à radição (Jacob et al., 1999; Nikiforov et al., 1997; Rabes et al., 2000; Tallini et al., 1998; Thomas et al., 1999). Ocorrem também em nódulos benignos com histórico de radiação, confirmando a relação direta entre alterações genéticas e exposição à radiação (Bounacer et al., 1997; Elisei et al., 2001).

As mutações no gene RAS podem ser provenientes de três genes que codificam quatro proteínas RAS distintas, todas homólogas e com 21 kDa: HRAS 
(cromossomo 11), NRAS (cromossomo 1), e KRAS (cromossomo 12). As proteínas RAS são encontradas na parte intracelular da membrana e respondem a estímulos extracelulares (por meio da ativação de receptores tirosina quinase e receptores ligados à proteína $\mathrm{G}$ ), sinalizando e ativando vias intracelulares.

Mutações em KRAS são as alterações ativadoras mais frequentes em diversos tipos de câncer (Pylayeva-Gupta et al., 2011), estando localizados em sua maioria nos codons 12 e 13 do éxon 2 (Russo et al., 2005; Suda et al., 2010). Talvez por isso, a maioria dos estudos também em tireoide tenha avaliado apenas os códons 12/13 (Nikiforov et al., 2011; Petersen et al., 2012). No entanto, os resultados são controversos e precisam ser melhor elucidados. Estudos recentes mostraram maior prevalência da mutação no códon 61 da proteína KRAS, contradizendo os achados anteriores (Park et al., 2013; Rivera et al., 2010).

Em geral, as mutações somáticas em RAS aparecem com diferentes frequências nas neoplasias de tireoide, sendo encontradas em 10-20\% dos casos de carcinoma papilífero (Esapa et al., 1999; Ezzat et al., 1996; Karga et al., 1991; Manenti, 1994; Motoi et al., 2000; Namba et al., 1990; Suarez et al., 1990).

\subsubsection{Vias de sinalização associadas}

Em CPT as mutações em BRAF, os rearranjos $R E T / P T C$ e mutações em RAS são mutuamente exclusivos, raramente sendo encontrados simultaneamente em pacientes (Kimura et al., 2003; Nikiforova et al., 2008; Soares et al., 2003). No entanto, estas alterações constituem mecanismos importantes de progressão do câncer, ativando a proliferação celular por meio de vias comuns de sinalização. De forma geral, independente do tipo de mutação, a ativação desregulada das vias de MAPK (RAS-RAF-MEK-MAPK-ERK) e PI3K/AKT parece exercer um papel importante no desenvolvimento e progressão do carcinoma papilífero de tireoide.

A via de MAPK é uma via de transdução de sinais intracelular iniciada a partir do estímulo de receptores tirosina quinase (RTK) localizados na superfície celular. A via pode ser ativada por diversos sinais extracelulares, entre eles, fatores de crescimento, hormônios e citocinas, resultando numa cascata de sinalização, necessária para a manutenção de atividades celulares como crescimento celular, proliferação, diferenciação e apoptose (MacCorkle, Tan, 2005; Robinson, Cobb, 1997). 
A ligação entre o ligante e o RTK leva à dimerização do receptor e à autofosforilação do resíduo tirosina com domínio intracelular. Uma vez ativado, proteínas adaptadoras (Grb2 e SOS) são recrutadas, ativando a quinase RAS. RAS recruta a quinase Raf para a membrana, onde será fosforilada e ativada. Em resposta Raf ativa duas proteínas específicas, as MAP quinases 1 e 2 (MAPKK, também conhecida como MAP/extracellular signal-regulated kinase - MEK). MEK1/2 fosforila e ativa as quinases ERK 1 e 2 (extracellular signal-regulated kinases), responsáveis pela regulação de vários fatores de transcrição que levam à expressão de genes relacionados à proliferação, sobrevivência, senescência e diferenciação.

A via de PI3K/AKT pode ser acionada de dois modos: pela ativação de receptores tirosina quinase ou de receptores ligados à proteína G (GPCRs, G protein coupled receptors), ou alternativamente pela ativação de Ras. No primeiro, a fosforilação do resíduo $Y$ no receptor mobiliza a subunidade regulatória p85 de PI3K (Chang et al., 2003). A subunidade catalítica p110 de PI3K é, então, recrutada para este complexo. No segundo, a ativação do receptor permite a ligação das proteínas Shc. A ligação dessa proteína ao receptor facilita a formação de um complexo protéico (Grb-2 e Sos), responsável pela ativação de Ras. Ativado, Ras recruta a subunidade p110 para a membrana, ativando PI3K.

Uma vez ativado, PI3K recruta Akt, ativando diversos fatores abaixo na cascata, que regulam a apoptose, proliferação e migração em vários sistemas celulares.

BRAF é um importante desencadeador de uma série de eventos ativadores ao longo da via de MAPK (Mercer, Pritchard, 2003; Nikiforov, 2008; Sithanandam et al., 1992; Xing, 2005) e a via de NF-kB em câncer de tireoide (Chou et al., 2010), evidenciando a importância dessa via no desenvolvimento do CPT (Davies et al., 2002). Os efeitos oncogênicos de RET/PTC se dão, em parte, pela via de MAPK na presença da quinase BRAF funcionando normalmente (Knauf et al., 2003; Melillo et al., 2005; Mitsutake et al., 2005). O proto-oncogene RET, que não é expresso em células normais da tireoide, passa a ser ativado, seja pela deslocalização do domínio TK de RET da membrana para o citoplasma, pela ausência da região reguladora extracelular de RET ou pela presença de um domínio "coiled-coil" na sequência codificadora de RET (favorece o processo de dimerização). Com domínio tirosina quinase intacto, o receptor permanece constitutivamente ativo, estimulando a via de MAPK e promovendo a tumorigênese nas células tireoidianas (Jhiang et al., 1996; 
Santoro et al., 1996). Outros estudos também descrevem a capacidade desta mutação de também ativar a via de AKT (PTEN/PI3K/AKT) (de la Chapelle, Jazdzewski, 2011).

As proteínas RAS são capazes de ativar tanto a via de MAPK quanto a de PI3K-AKT. No entanto, parece haver uma preferência de ativação da via PI3K-AKT nos tumores de tireoide. Isso sugere uma associação preferencial das mutações em RAS e a fosforilação de AKT em neoplasias tireoidianas (Abubaker et al., 2008; Liu et al., 2008). AKT parece ter papel importante na formação de tumor e progressão de carcinomas de tireoide (Shinohara et al., 2007). A atividade elevada de AKT está associada ao aumento da atividade de PI3K ou à diminuição da atividade de PTEN. Eventos estes que foram relacionados a maior capacidade de invasão em carcinoma papilífero de tireoide (Shinohara et al., 2007).

Em resumo, a via de AKT é ativada em casos de CPT contendo rearranjos em RET/PTC ou em mutações em RAS, mas parece estar ausente em casos positivos para a mutação em BRAF, em que há ativação preferencial da via de MAPK. A compreensão dos mecanismos moleculares envolvidos na iniciação e progressão das neoplasias de tireoide pode significar melhorias nas estratégias de tratamento dessas neoplasias. No entanto, os mecanismos moleculares precisam ser melhor elucidados.

\subsection{MicroRNAs e o carcinoma papilífero}

Uma das primeiras evidências relacionando alteração da expressão de miRNAs e o carcinoma papilífero de tireoide foi descrita por He e colaboradores (2005). Desde então, diversos grupos vêm tentando entender o papel destas pequenas moléculas no desenvolvimento e progressão da neoplasia. Alguns destes trabalhos estão resumidos na tabela 3.

Utilizando diferentes técnicas para a análise de expressão de miRNAs e tipos diversos de material (desde amostras frescas, emblocadas em parafina, de punção aspirativa por agulha fina, até linhagens celulares), as evidências experimentais mostram miRNAs mais expressos nas amostras tumorais quando comparadas a amostras de bócio multinodular (MNG) (Tetzlaff et al., 2007) e de tireoide normal (Nikiforova et al., 2008). Além disso, níveis de expressão de miRNAs variam quando 
comparados tumores malignos de tireoide (carcinoma papilífero, carcinoma folicular, carcinoma anaplásico e carcinoma de células de Hürthle) com tecidos livres de tumor (tireoide normal ou bócio multinodular) e tumores benignos (adenoma folicular) (Kitano et al., 2011; Vriens et al., 2011), estando alguns deles mais expressos nos tumores malignos. Um grupo restrito de miRNAs também é encontrado mais expressos em CPTs mais agressivos (com metástase em linfonodo) quando comparados a CPT menos agressivos (sem metástases linfonodais) (Yip et al., 2011). 
Tabela 3: Estudos envolvendo o perfil de expressão de microRNAs em carcinoma papilífero de tireoide. A tabela mostra uma lista de artigos publicados sobre a desregulação da expressão de microRNAs, evidenciando o tipo de amostra analisada, o método de análise empregado e os microRNAs encontrados superexpressos e pouco expressos neste tipo de tumor. Adaptada de Marini et al., 2011 e Lodewijk et al., 2012.

\begin{tabular}{|c|c|c|c|c|c|c|c|}
\hline Estudo & $\begin{array}{l}\text { RET/PTC } \\
\text { (método) }\end{array}$ & $\begin{array}{l}\text { BRAFV600E } \\
\text { (método) }\end{array}$ & RAS (método) & Amostras utilizadas & Métodos/tipo de tecido & $\begin{array}{c}\text { miRNAs } \\
\text { superexpressos no } \\
\text { tumor }\end{array}$ & $\begin{array}{l}\text { miRNAs pouco } \\
\text { expressos no } \\
\text { tumor }\end{array}$ \\
\hline \multirow[t]{2}{*}{$\begin{array}{l}\text { He et al., } \\
2005\end{array}$} & Não avaliado & Não avaliado & Não avaliado & $\begin{array}{l}15 \mathrm{CPT}, 10 \text { tecidos } \\
\text { adjacentes }\end{array}$ & $\begin{array}{l}460 \text { miRNA microarray, } \\
\text { qRT-PCR, Northern } \\
\text { Blot; amostra de tecido } \\
\text { fresco congelado }\end{array}$ & $\begin{array}{l}\text { CPT vs. tecido } \\
\text { adjacente: miR-146, } \\
221,222,21,220, \\
181 a, 181 c, 181,155\end{array}$ & $\begin{array}{l}\text { CPT vs. } \\
\text { adjacente: - }\end{array}$ \\
\hline & & & & $\begin{array}{l}30 \mathrm{CPT}, 10 \text { tecido do outro } \\
\text { lobo }\end{array}$ & & & \\
\hline \multirow[t]{2}{*}{$\begin{array}{l}\text { Pallante et } \\
\text { al., } 2006\end{array}$} & Não avaliado & Não avaliado & Não avaliado & $\begin{array}{l}\text { Linhagens humanas: TPC-1 } \\
\text { (RET/PTC1), NPA (PDTC), } \\
\text { B-CPAP (BRAF) e FB-2 } \\
\text { (RET/PTC1) }\end{array}$ & $\begin{array}{l}368 \text { miRNA microarray; } \\
\text { amostra de tecido } \\
\text { fresco congelado }\end{array}$ & $\begin{array}{l}\text { CPT vs. outro lobo: } \\
\text { miR-222, } 221,181 b \text {, } \\
220,213\end{array}$ & $\begin{array}{l}\text { CPT vs. outro } \\
\text { lobo: - }\end{array}$ \\
\hline & & & & $\begin{array}{l}\text { Linhagem PCCI } 3 \\
\text { transformada com v-ras-Ha, } \\
\text { v-ras-Ki, v-raf, RET/PTC1, } \\
\text { RET/PTC3, E1AAbl, E1A-raf, } \\
\text { PyPMLV e v-mos }\end{array}$ & & & \\
\hline $\begin{array}{l}\text { Cahill et al., } \\
2006\end{array}$ & & Não avaliado & Não avaliado & $\begin{array}{l}\text { Linhagem celular com } \\
\text { RET/PTC1 (TPC-1 e Nthy-ori } \\
\text { 3-1- Ret), linhagem celular } \\
\text { normal (Nthy-ori 3-1) }\end{array}$ & $\begin{array}{l}\text { Global miRNA } \\
\text { microarray }\end{array}$ & $\begin{array}{l}\text { miR-34a,-96,-99a,-- } \\
100,-125 b,-128 b,- \\
130 b,-139,-141,-142- \\
3 p,-146,-148,-185,- \\
200 a,-200 b,-211,- \\
213,-216, l e t-7 d\end{array}$ & $\begin{array}{l}\operatorname{miR}-15 a,-34 c,- \\
107,-127,-135 b,- \\
145,-149,-154,- \\
181 a,-218,-299,- \\
\text { 302b,-302c,-323,-- } \\
370\end{array}$ \\
\hline $\begin{array}{l}\text { Cahill et al., } \\
2007\end{array}$ & Não avaliado & & Não avaliado & $\begin{array}{l}\text { Linhagem celular com } \\
\text { BRAFV600E (Nthy-oriBRAF } \\
\text { e KAT-10), linhagem celular } \\
\text { normal (Nthy-ori 3-1) }\end{array}$ & $\begin{array}{l}\text { Global miRNA } \\
\text { microarray }\end{array}$ & $\begin{array}{l}\text { miR-128a,-128b,- } \\
\text { 135a,-141,-150,-185,-- } \\
\text { 200a,-200b,-200c,-- } \\
\text { 203,-213,-215,-330,- }\end{array}$ & $\begin{array}{l}\text { miR-122a, -127,- } \\
\text { 130a,-137,-138,-- } \\
\text { 144,-155,-181b,-- } \\
\text { 187,-190,-193,-- } \\
197,-222,-302 b,-\end{array}$ \\
\hline
\end{tabular}


Tetzlaff et al., 2007

Nikiforova et al., 2008

\section{RET/PTC1 e}

RET/PTC3:

RT-PCR
$338,-34 a$

754 miRNA microarray; tecido emblocado em

parafina

158 miRNA microarray; amostra de tecido
Não avaliado

Não avaliado

$10 \mathrm{CPT}, 10 \mathrm{MNG}$

NRAS codon

61, HRAS

codon 61 ,

KRAS codons

12/13: qRT-

PCR

qRT-PCR
9 CPT, 5 FTC, 2 pd-CPT, 2 ATC, 4 FA, 5 NT, $2 \mathrm{HN}, 2$ $\mathrm{MC}$ fresco congelado

miRNAs; qRT-PCR; tecido emblocado em parafina

3 miRNAs; qRT-PCR; amostra de punção aspirativa por agulha fina

50 c-CPT, 71 tc-CPT, $56 \mathrm{fv}$ Sequenciamento por método de Sanger
Não avaliado
CPT, 44 micro-CPT, tecido adjacente
5 miRNAs; $q R T-P C R$; tecido emblocado em parafina
CPT vs. MNG: miR221, 222, 21, 31, 172 $34 a, 213,181 b, 223$

CPT vs. NT: miR-187, 221, 222, 146b, 155, 122a, 31, 205, 224 c-FTC vs. NT: miR$187,224,155,222$ $221,146 b$

o-FTC vs. NT: miR $187,221,339,183$ 222, 197

PDTC vs. NT: miR$187,221,129,222$ 146b, 339, 183

ATC vs. NT: miR302c, 205, 137, 187 $214,155,224,222$ 221

CPT vs. não CPT: $\mathrm{miR}-146 \mathrm{~b}$

CPT vs benigno: miR146b,-222

-CPT vs adjacente: miR-146b, 221, 222 micro-CPT vs.
CPT vs. não CPT:

302c,-323,-335,$339,-342,-34 c$,370

CPT vs. MNG: miR-218, 300, 292, 345

CPT vs. benigno:

umor vs. Tecido adjacente: - 
Schwertheim et al., 2009

Sheu et al. 2009

\section{Não avaliado}

Sequenciamento por método de Sanger

Sheu et al., 2010
Não avaliado

BRAF V600E e K601E: qRTPCR, e

Yip et al.,

2011
qRT-PCR sequenciamento por método de Sanger
15 PDTC, 9 CPT, 9 ATC, 4 NT

Não avaliado

$(\mathrm{n}=28)$ versuşão em BRAF

$(\mathrm{n}=28)$ versus CPT sem

mutação em BRAF ( $n=26)$

50 CPT (10 c-CPT, 10 tc-

CPT, $30 \mathrm{fv}$-CPT), 21 FTC, 105 miRNAs; tecido

FA, 10 MNG

Não avaliado

\section{NRAS codon}

61, HRAS

codon 61 ,

KRAS codons

$$
\text { PCR, e }
$$

sequenciamento

por método de

parafina
12 and 13: qRT-

adjacente: miR-146b,

221, 222, 181b, 21

tc-CPT vs. adjacente: miR-146b, 221, 222 , 21

fv-CPT vs. adjacente: miR-146b, 222, 221

CPT vs. NT: $146 \mathrm{~b}$

222, 221, 21, 181b

30d, 125d, 26a, 304-

$5 p$, let-7c

PDTC vs. NT: -

ATC vs. NT: 21, 222

$221,146 \mathrm{~b}, 181 \mathrm{~b}$

5 miRNA; qRT-PCR

tecido emblocado em

Sem diferença entre

CPT com e sem

mutação

CPT vs. adjacente:

miR-146b, 221, 222,

21, 181b

fv-CPT vs. adjacente: miR-146b, 221, 222 ,

FTC vs. adjacente: -

319 miRNA microarray;

12 CPT, 4 NT $\quad \begin{aligned} & \text { amostra de tecido } \\ & \text { fresco congelado }\end{aligned}$

CPT vs. NT: miR

CPT vs. NT: miR

CPT vs. NT: -

PDTC vs. NT:

26a, 125d, let-7c

ATC vs. NT: let-

7c, 30d, 26a, 304

$5 p, 125 d$

Sem diferença entre CPT com e sem mutação

CPT vs.

adjacente: -

fv-CPT vs.

adjacente: -

FTC vs.

adjacente: $\mathrm{miR}$ -

221, 21, 222

$146 \mathrm{~b}$

146b, 222, 155, 221 ,

138, 1, 130b 
Sanger

\begin{tabular}{|c|c|c|c|c|c|c|c|}
\hline $\begin{array}{l}\text { Kitano et al., } \\
2011\end{array}$ & Não avaliado & Não avaliado & Não avaliado & $\begin{array}{l}8 \mathrm{HCC}, 6 \mathrm{CPT}, 6 \mathrm{fv}-\mathrm{CPT}, 6 \\
\mathrm{FTC}, 6 \text { FA, } 8 \text { MNG, } 7 \mathrm{HA}\end{array}$ & $\begin{array}{l}1263 \text { miRNA } \\
\text { microarray; amostra de } \\
\text { tecido fresco congelado }\end{array}$ & $\begin{array}{l}\text { Maligno vs. benigno: } \\
\text { miR-146b-5p, } 222\end{array}$ & $\begin{array}{l}\text { Maligno vs. } \\
\text { benigno: miR- } \\
451,7,144\end{array}$ \\
\hline $\begin{array}{l}\text { Vriens et al., } \\
2012\end{array}$ & Não avaliado & Não avaliado & Não avaliado & $\begin{array}{l}12 \mathrm{fv}-\mathrm{CPT}, 8 \mathrm{c}-\mathrm{CPT}, 15 \mathrm{FA} \text {, } \\
12 \mathrm{FTC}, 12 \mathrm{HCC}, 4 \mathrm{ATC}, 7 \\
\text { NT, } 14 \mathrm{HN}\end{array}$ & $\begin{array}{l}\text { 850miRNA } \\
\text { microarray; amostra de } \\
\text { tecido fresco congelado }\end{array}$ & $\begin{array}{l}\text { Maligno vs. benigno: } \\
\text { miR-584, } 635,564 \text {, } \\
550,628-3 p\end{array}$ & $\begin{array}{l}\text { Maligno vs. } \\
\text { benigno: miR- } \\
\text { 149, 100, 138, } \\
\text { 125b, 768-3p }\end{array}$ \\
\hline $\begin{array}{l}\text { Chou et al., } \\
2010\end{array}$ & RT-PCR & $\begin{array}{l}\text { Sequenciamento } \\
\text { por método de } \\
\text { Sanger }\end{array}$ & Não avaliado & $100 \mathrm{CPT}, 16 \mathrm{NT}$ & $\begin{array}{l}3 \text { miRNAs; amostra } \\
\text { fresca congelada }\end{array}$ & $\begin{array}{l}\text { CPT vs. NT: miR- } \\
\text { 146b, 221, } 222\end{array}$ & CPT vs. NT: - \\
\hline $\begin{array}{l}\text { Mazeh et al., } \\
2011\end{array}$ & Não avaliado & Não avaliado & Não avaliado & $\begin{array}{l}20 \mathrm{CPT}, 20 \text { tecido adjacente, } \\
2 \mathrm{MNG}, 3 \mathrm{GD}, 2 \mathrm{TA}\end{array}$ & $\begin{array}{l}6 \text { miRNAs; amostra } \\
\text { fresca de punção } \\
\text { aspirativa por agulha } \\
\text { fina }\end{array}$ & $\begin{array}{l}\text { CPT vs. Tecido } \\
\text { adjacente: miR-146b, } \\
\text { 221, 222, 187, 31, } 21\end{array}$ & $\begin{array}{l}\text { CPT vs. Tecido } \\
\text { adjacente: - }\end{array}$ \\
\hline $\begin{array}{l}\text { Keutgen et } \\
\text { al., } 2012\end{array}$ & Não avaliado & Não avaliado & Não avaliado & $\begin{array}{l}12 \mathrm{c}-\mathrm{CPT}, 1 \mathrm{pd}-\mathrm{CPT}, 16 \mathrm{fv}- \\
\text { CPT, } 6 \text { FTC, } 1 \mathrm{HCC}, 22 \mathrm{FA} \text {, } \\
43 \mathrm{HN}, 22 \mathrm{TH}\end{array}$ & $\begin{array}{l}6 \text { miRNAs; amostra } \\
\text { fresca de punção } \\
\text { aspirativa por agulha } \\
\text { fina }\end{array}$ & maligno vs. benigno: - & $\begin{array}{l}\text { maligno vs. } \\
\text { benigno: miR- } \\
197,328\end{array}$ \\
\hline $\begin{array}{l}\text { Shen et al., } \\
2012\end{array}$ & Não avaliado & Não avaliado & Não avaliado & $\begin{array}{l}3 \mathrm{ATC}, 5 \mathrm{FTC}, 32 \mathrm{CPT}, 4 \mathrm{fv}- \\
\text { CPT, } 6 \text { FA, } 1 \text { HA, } 8 \mathrm{NH}, 1 \\
\text { NNG }\end{array}$ & $\begin{array}{l}8 \text { miRNAs; amostra } \\
\text { fresca de punção } \\
\text { aspirativa por agulha } \\
\text { fina }\end{array}$ & maligno vs. benigno: - & $\begin{array}{l}\text { maligno vs. } \\
\text { benigno: miR- } \\
\text { 146b, } 221\end{array}$ \\
\hline $\begin{array}{l}\text { Sun et al., } \\
2013\end{array}$ & Não avaliado & $\begin{array}{l}\text { Sequenciamento } \\
\text { por método de } \\
\text { Sanger }\end{array}$ & Não avaliado & 52 CPT, 52 BTN & $\begin{array}{l}5 \text { miRNAs } \\
\text { selecionados; amostra } \\
\text { parafinada }\end{array}$ & $\begin{array}{l}\text { CPT vs. BTN: miR- } \\
146 \mathrm{~b}, 222,221,181 \\
21\end{array}$ & CPT vs. BTN: - \\
\hline
\end{tabular}

CPT: carcinoma papilífero de tireoide; MNG: bócio multinodular; FTC: carcinoma folicular de tireoide; pd-CPT: CPT pouco diferenciado; ATC: carcinoma anaplásico de tireoide;

FA: adenoma folicular; HN: nódulo hiperplásico; MC: carcinoma medular; NT: tecido normal de tireoide; HÁ: adenoma de células de Hürthle; HCC: carcinoma de células de Hürthle; GD: doença de Graves; TH: tireoidite; NNG: bócio não neoplásico; BTN: nódulo tireoideano benigno. 
De maneira geral, os estudos de expressão de miRNAs mostraram maiores diferenças de expressão para os miR-221, miR-222 e miR-146b nas amostras de CPT quando comparadas a tecidos normais de tireoide, bócio multinodular e adenoma folicular. No entanto, nem os valores de expressão, nem os mesmos miRNAs são observados com consistência por todos grupos, evidenciando a complexidade do uso de amostras biológicas.

Quanto aos miRNAs pouco expressos em tumores com relação a amostras não tumorais, os resultados não são consistentes, sendo miR-138, miR-1345 e miR130b os que aparecem em mais estudos (He et al., 2005; Pallante et al., 2006; Tetzlaff et al., 2007; Yip et al., 2011).

A associação entre mutações frequentes e a expressão de miRNAs também tem sido um campo explorado nos estudos de carcinoma papilífero. De forma geral, parece haver uma relação entre a expressão do miR-146b (Chou et al., 2010; Nikiforova et al., 2008; Sun et al., 2013), miR-221, miR-222 (Nikiforova et al., 2008; Sun et al., 2013) e miR-181 (Sun et al., 2013) e a presença da mutação BRAF, estando eles significativamente mais expressos nos tumores com a mutação quando comparado a tumores sem a mutação. Trabalhos diversos não conseguiram estabelecer quaisquer relações entre a presença da mutação e maior expressão gênica de miRNAs (Sheu et al., 2009; Sun et al., 2013).

Em relação a outras mutações observadas em CPT, o miR-187 é encontrado mais expresso em amostras tumorais contendo rearranjo RET/PTC ou mutação em RAS, apresentando expressão significativamente menor em tumores positivos para a mutação BRAF (Nikiforova et al., 2008).

O perfil de expressão de miRNAs em algumas linhagens celulares humanas de CPT contendo as mutações RET/PTC1 ou BRAF mostrou-se distinto quando comparado a linhagens sem quaisquer mutações (Cahill et al., 2006; Cahill et al., 2007). No entanto, alguns miRNAs em comum são observados mais expressos na presença de ambas mutações, sugerindo uma regulação fina da via de sinalização comum entre essas duas mutações. Por exemplo, os miRNAs miR-221, miR-222 e miR181b são encontrados mais expressos em linhagens contendo as mutações em BRAF, RET/PTC ou RAS (Pallante et al., 2006). Os resultados são, no entanto, inconclusivos, variando de acordo com a linhagem estudada (Cahill et al., 2007). 
Apesar das evidências do possível papel dos miRNAs no desenvolvimento e progressão do carcinoma papilífero, os resultados são pouco conclusivos, evidenciando a necessidade de maiores investigações.

\subsection{0 papel funcional de microRNAs em carcinoma papilífero}

Evidências crescentes mostram os microRNAs como componentes importantes de diversas vias canônicas de sinalização, que sofrem ganho ou perda de função ao longo do processo carcinogênico, incluindo as de MAPK e de PI3K/AKT. A associação entre miRNAs e moléculas alvos presentes nestas vias também tem sido um campo explorado nos estudos de carcinoma papilífero. Uma ilustração de uma possível atuação de miRNAs nas vias de MAPK e PI3K/AKT está representada na figura 2 .

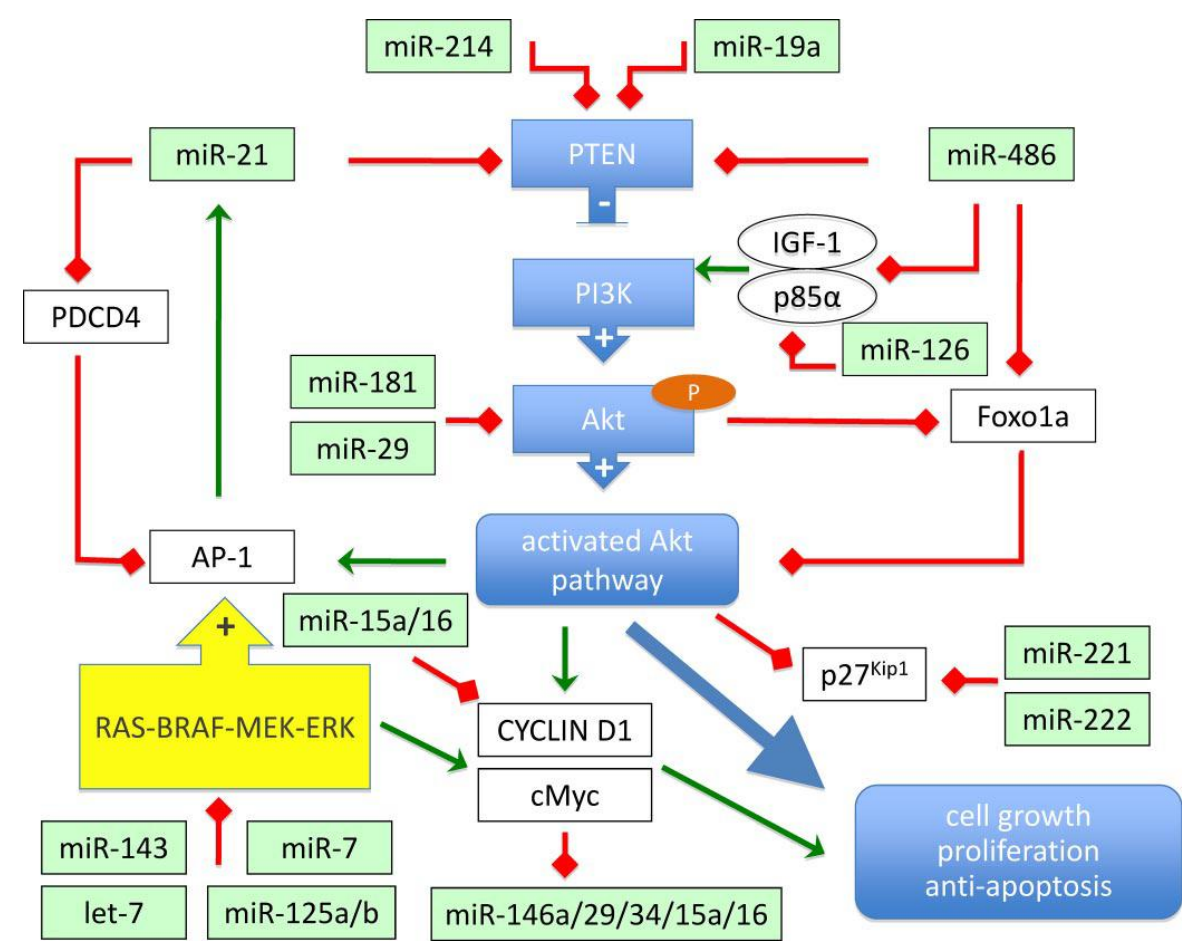

Figura 2: Regulação das vias RAS/BRAF/MEK/ERK e PTEN/PI3K/AKT por miRNAs. Fonte: de la Chapelle, Jazdzewski, 2011.

Entre os alvos de miRNAS miR-146b, miR-221 e miR-222 estão os genes CDKN1B (p27(kip1)) e p57/kip2, importantes reguladores de ciclo celular (P27(Kip1) se liga a Cdk2-cyclin $E$ e impede a transição G1-S) inibido quando a via de PI3K/AKT é ativada (Liang et al., 2002; Malashicheva et al., 2002; Shin et al., 2002; Viglietto et al., 2002; Visone et al., 2007). A diminuição dos níveis desta proteína foi 
relacionada diretamente ao aumento da expressão destes miRNAs não só em CPT (Visone et al., 2007), mas em glioblastoma (Gillies, Lorimer, 2007; le Sage et al., 2007) e câncer de próstata (Galardi et al., 2007).

Outro alvo direto destes miRNAs é o KIT, um receptor de tirosina quinase com papel importante no crescimento celular e diferenciação, atuando como um oncogene em muitos tipos de câncer (Ashman, 1999; Kitamura, Hirotab, 2004) através da ativação das vias de MAPK e PI3K (Todd et al., 2012). A superexpressão dos miRNAs miR-146b, miR-221 e miR-222 foi associada à diminuição dramática de $\mathrm{KIT}$, tanto proteína quanto transcrito (He et al., 2005). Acredita-se que, em tecidos de tireoide, a via de sinalização de c-KIT controle alguns aspectos de diferenciação do tireócito ao invés de proliferação celular. A proteína é encontrada ausente em CPTs, sugerindo sua associação com o fenótipo maligno das células neoplásicas de tireoide (Natali et al., 1995).

MiR-221 e miR-222 são capazes ainda de atuar diretamente sobre PTEN, levando à diminuição do crescimento celular, invasão e migração, ao inibir sua expressão ao longo da via de PI3K/AKT (Chun-Zhi et al., 2010). PTEN também pode ser regulado negativamente pelo miR-486. A inibição de PTEN e de Foxo1a (também alvo de miR-486) leva à fosforilação de AKT, ativando a via. No entanto, a ativação de AKT leva a fosforilação de GSK3ß e inibição da atividade de Foxo1a, inibindo a via de PI3K/AKT através de um mecanismo de feedback negativo (Small et al., 2010).

Apesar dos esforços para entender o papel dos miRNAs no desenvolvimento e progressão do carcinoma papilífero, os estudos funcionais envolvendo miRNAs e seus alvos são ainda preliminares. Pouco se sabe sobre como essas pequenas moléculas atuam nas vias de sinalização mais frequentemente ativas, evidenciando a necessidade de ampliação neste campo de pesquisa.

\subsection{Identificação de microRNAs em amostras biológicas}

Os miRNAs apresentam grande potencial para a pesquisa, visto que, ao contrário dos demais ácidos nucléicos, permanecem bem conservados, inclusive em material emblocado em parafina (Weber et al., 2006). Inclusive são facilmente extraídos de amostras parafinadas devido ao seu pequeno tamanho (Zhang et al., 
2008). A possibilidade de avaliar miRNAs em amostras parafinadas tornou-os biomarcadores interessantes (Hui et al., 2011; Osaki et al., 2008).

Diversos estudos obtiveram sucesso com esse tipo de abordagem para a detecção de miRNAs em tumores de tireoide (Chen et al., 2008; Sheu et al., 2010; Visone et al., 2007). Além disso, alguns trabalhos mostraram que os perfis de expressão de miRNAs obtidos de material parafinado se assemelham ao obtido de materiais frescos (Farragher et al., 2008; Xi et al., 2007).

Além dos miRNAs, diversos grupos mostraram também ser possível obter DNA genômico de material parafinado (Bonin et al., 2010; Tang et al., 2009), mesmo com o processo de fixação em formalina levando à ligação cruzada entre DNA e proteína (Gilbert et al., 2007) e do formaldeído permeando o tecido ser alterado a ácido fórmico, induzindo quebras na cadeia de DNA (Feldman, 1973; Ferrer et al., 2007; Gilbert et al., 2007; Hewitt et al., 2008; Klopfleisch et al., 2011; Pavelic et al., 1996). Devido à fragmentação relacionada à idade da amostra e condições usadas na sua fixação, a técnica apresenta, portanto, algumas limitações, e parece ser válida apenas para análise de sequências curtas, entre 100 pb e 300 pb de tamanho (Bonin et al., 2003; Largey et al., 1993; Lewis et al., 2001).

Uma desvantagem importante quando se utiliza o material parafinado consiste na heterogeneidade das amostras: em um mesmo corte podem ser observados além do tumor, outros tipos de tecido, tais como tecido livre de tumor e células estromais como fibroblastos, linfócitos e células vasculares endoteliais (Ma et al., 2009). Além disso, esses materiais podem ocorrer em diferentes proporções no corte, o que pode afetar o padrão de expressão gênica, impedindo uma análise precisa do perfil de expressão das células cancerígenas (de Bruin et al., 2005; Sugiyama et al., 2002). Este fato demanda cuidado ao avaliar os resultados, já que nem sempre remetem às propriedades biológicas do próprio tumor (Inoue et al., 2009). Alternativas utilizadas para minimizar o problema da heterogeneidade das amostras parafinadas são a técnica de microdissecção a laser e a de macro-dissecção histológica.

$\mathrm{Na}$ microdissecção isola-se a área tumoral através de um corte a laser. Porém, a técnica pode levar à degradação do material, além de demandar amplificação do RNA para obtenção de quantidade suficiente para realizar as análises de expressão (Michel et al., 2003; Miura et al., 2002). A análise de padrões de expressão gênica em amostras microdissecadas submetidas à amplificação pode apresentar baixo coeficiente de correlação quando comparado a amostras não 
amplificadas, levando à perda de informações relevantes (Boelens et al., 2007; Nygaard et al., 2003; Scheidl, et al., 2002; Zhao et al., 2002).

Já na técnica de macro-dissecção, a área de interesse é isolada por recortes manuais, guiados por análise microscópica de uma lâmina corada com Hematoxilina \& Eosina. Ocorre maior contaminação com células estromais (Kim et al., 2011). Porém, a contribuição dos componentes estromais parece não ser tão relevante nos resultados de expressão gênica, correspondendo ao fenótipo tumoral (de Bruin et al., 2005).

Outra técnica possível é a análise do material histológico por morfometria. A morfometria é um método quantitativo realizado através da análise de uma imagem digitalizada. Essa técnica permite o cálculo da área dos diversos tipos de tecidos presentes no material obtido por ressecção. A partir de uma ferramenta computacional, mensura-se o perímetro total do corte histológico corado com Hematoxilina \& Eosina e o perímetro da área tumoral. Consequentemente, é possível obter os valores precisos de porcentagem de cada um desses tecidos na amostra analisada, o que permite a avaliação mais precisa das características dos tecidos parafinados (Sabarense et al., 2012).

\subsection{Justificativa do projeto}

Com base nesses estudos, acredita-se que miRNAs devam exercer um papel importante na regulação de genes associados com o desenvolvimento de CPT, e seu estudo pode contribuir para uma melhor compreensão do papel das mutações geralmente detectadas. Neste trabalho pretende-se avaliar o perfil de expressão dos miRNAs em amostras de CPT caracterizadas quanto à presença de mutações frequentes, buscando, assim, uma melhor compreensão dos mecanismos moleculares associados a essa patologia, bem como, a identificação de possíveis marcadores diagnósticos e/ou para melhor compreensão das alterações genéticas associadas a seu prognóstico.

Isolaremos os miRNAs e avaliaremos a presença de mutação em tecidos biológicos preservados em parafina, uma abordagem de grande valor devido à disponibilidade deste tipo de material associado ao histórico clínico completo dos pacientes diagnosticados com carcinomas de tireoide. 
Pouco se sabe sobre os efeitos da heterogeneidade das amostras sobre o resultado da expressão gênica global de uma determinada molécula, sendo este, portanto, uma avaliação adicional deste trabalho. 


\section{OBJETIVOS}

\subsection{Objetivo geral}

Avaliar o perfil de expressão dos miRNAs em amostras de CPT caracterizadas quanto à presença de mutações frequentes, buscando, assim, uma melhor compreensão dos mecanismos moleculares associados a essa patologia.

\subsection{Objetivos específicos}

- Padronização das técnicas de extração de DNA e RNA para a avaliação de expressão de miRNAs por PCR em tempo real e sequenciamento tradicional em amostras parafinadas.

- Caracterização das amostras quanto à presença da mutação T1799A em BRAF $\left(B R A F^{V 600 E}\right)$ por sequenciamento tradicional, da translocação RET/PTC1 e RET/PTC3, e das mutações em RAS códon 12/13 e códon 61 .

- Avaliação da expressão de miRNAs por PCR em tempo real em amostras parafinadas contendo tumor e amostras livres de tumor e associação dos resultados com a presença ou ausência de mutações.

- Avaliar a interferência da heterogeneidade das amotras emblocadas na expressão de miRNAs.

- Avaliação da expressão global de miRNAs por microarrays entre amostras positivas e negativas para a mutação BRAF $^{\mathrm{V} 600 \mathrm{E}}$

- Validação de resultados observados em microarrays em amostras adicionais de CPT. 


\section{MATERIAIS E MÉTODOS}

\subsection{Comitê de ética}

Este trabalho faz parte do projeto intitulado: "Identificação de biomarcadores em neoplasias de cabeça e pescoço e tireoide através do estudo de miRNAs isolados de amostras de tecido parafinado e fresco" aprovado no Comitê de Ética em Pesquisa do Hospital Israelita Albert Einstein, sob responsabilidade da Dra. Patrícia Severino, conforme documento apresentado.

\subsection{Casuística}

Foram selecionados 51 pacientes - 26 casos do Departamento de Cirurgia de Cabeça e Pescoço do Instituto Brasileiro de Controle do Câncer em São Paulo e 25 casos de clínica privada, também em São Paulo - todos portadores de Carcinoma Papilífero de Tireoide tratados cirurgicamente entre 1999 e 2010, para estudo retrospectivo.

Foram incluídos apenas os pacientes cujos dados clínicos e anatomopatológicos constavam em seus prontuários médicos e cujos espécimes cirúrgicos encontravam-se disponíveis e razoavelmente conservados para que o estudo pudesse ser realizado após comprovação do diagnóstico e da presença de tumor correspondente no material parafinado.

Todos os pacientes foram submetidos à tireoidectomia total, ou à tireoidectomia total e esvaziamento cervical nos casos de metástases linfonodais cervicais presentes ao diagnóstico inicial. Nenhum paciente apresentou metástase à distância.

Como referência para o estadiamento dos pacientes estudados foi utilizado o sistema de classificação TNM UICC 7ª edição ${ }^{1}$, atualizado em 2009.

As características clínico-patológicas revisadas encontram-se na tabela 4.

\footnotetext{
${ }^{1}$ Sobin LH, Wittekind C, eds. UICC: TNM classification of malignant tumors, 7th ed. New York: WileyLiss, 2009
} 
Tabela 4: Características clínico-patológicas dos casos de CPT ( $n=51)$ e de amostras livres de tumor ( $n=2)$ incluídos neste estudo.

\begin{tabular}{|c|c|c|c|c|c|c|}
\hline Paciente & Sexo & $\begin{array}{l}\text { Idade } \\
\text { (anos) }\end{array}$ & $\begin{array}{l}\text { Data da } \\
\text { cirurgia }\end{array}$ & Diagnóstico & Estadiamento (TNM) & Ensaio realizado \\
\hline TIR1 & $M$ & 50 & mar.2008 & CPT-cv & pT1bN0M0 & (a), (d) \\
\hline TIR2 & $\mathrm{F}$ & 60 & mai.2008 & CPT-cv & pT3NOMO & (a), (e) \\
\hline TIR3 & $\mathrm{F}$ & 62 & out.2008 & CPT-fv & pT3N0M0 & (d) \\
\hline TIR4 & $\mathrm{F}$ & 39 & out.2008 & CPT-cv & pT3(m)NOMO & (a) \\
\hline TIR5 & $\mathrm{F}$ & 24 & fev.2009 & CPT-fv & pT1bNOMO & (a), (d) \\
\hline TIR6 & $\mathrm{F}$ & 56 & abr.2009 & CPT-fv & pT1aNOMO & (a), (d) \\
\hline TIR48 & $\mathrm{F}$ & 60 & mai.2007 & CPT-cv & pT1aNOMO & (b), (d) \\
\hline TIR49 & $\mathrm{F}$ & 26 & jun.2007 & TFT & & (b) \\
\hline TIR50 & $\mathrm{F}$ & 28 & set.2007 & CPT-cv & pT3(m)NOMO & (d) \\
\hline TIR51 & $\mathrm{F}$ & 44 & set.2007 & CPT-cv & $\mathrm{pT} 1 \mathrm{a}(\mathrm{m}) \mathrm{N} 0 \mathrm{MO}$ & (d) \\
\hline TIR52 & $\mathrm{F}$ & 23 & set.2007 & CPT-cv & pT3NOMO & (d) \\
\hline TIR53 & $\mathrm{F}$ & 46 & nov.2007 & CPT-cv & pT4a(m)NOM0 & (d) \\
\hline TIR54 & $\mathrm{F}$ & 62 & jul.2008 & CPT-cv & $\mathrm{pT} 1 \mathrm{a}(\mathrm{m})$ NOMO & (b), (d), (e) \\
\hline TIR55 & $\mathrm{F}$ & 36 & nov.2008 & CPT-cv & pT1aNOMO & \\
\hline TIR56 & $\mathrm{F}$ & 43 & fev.2009 & CPT-cv & pT1aNOMO & (b), (c), (d), (e) \\
\hline TIR57 & $\mathrm{F}$ & 50 & mar.2009 & CPT-fv & pT1aNOMO & (b), (d) \\
\hline TIR58 & $\mathrm{F}$ & 66 & mar.2009 & CPT-cv & pT3NOMO & (b), (d) \\
\hline TIR59 & $\mathrm{F}$ & 57 & jun.2009 & CPT-fv & pT1bN0M0 & (b), (c), (d), (e) \\
\hline TIR60 & $\mathrm{F}$ & 47 & jul.2009 & CPT-cv & pT1aNOMO & (b), (d), (e) \\
\hline TIR61 & $\mathrm{F}$ & 71 & jul.2009 & CPT-fv & pT3NOMO & (b), (c), (d) \\
\hline TIR62 & $\mathrm{F}$ & 78 & out.2009 & CPT-cv & pT2(m)NOMO & (b), (d) \\
\hline TIR63 & M & 22 & dez.2007 & CPT-cv & pT1apN1bM0 & (c), (d) \\
\hline TIR64 & M & 78 & jun.2007 & CPT-cV & pT3pN1aM0 & (c), (d) \\
\hline TIR65 & M & 24 & jun.2007 & CPT-fv & pT1bNOMO & (d) \\
\hline TIR66 & $\mathrm{F}$ & 44 & ago.2007 & CPT-cv & $\mathrm{pT} 1 \mathrm{a}(\mathrm{m}) \mathrm{N} 0 \mathrm{M0}$ & (d) \\
\hline TIR67 & M & 52 & ago.2007 & CPT-cV & pT1aNOM0 & \\
\hline TIR68 & $\mathrm{F}$ & 49 & dez.2007 & CPT-fv & pT3(m)NOMO & (d) \\
\hline TIR70 & $\mathrm{F}$ & 61 & out.2007 & CPT-fv & pT3(m)NOMO & (c), (d) \\
\hline TIR71 & $\mathrm{F}$ & 33 & jun.2007 & CPT-cv & pT1aNOMO & (d) \\
\hline TIR72 & M & 43 & nov.2007 & CPT-fv & pT1b(m)NOM0 & (d) \\
\hline TIR73 & $\mathrm{F}$ & 38 & ago.2007 & CPT-cv & $\mathrm{pT} 1 \mathrm{~b}(\mathrm{~m}) \mathrm{NOMO}$ & (d) \\
\hline TIR74 & $\mathrm{F}$ & 65 & out.2007 & CPT-fv & pT3(m)NOMO & (d) \\
\hline TIR75 & $\mathrm{F}$ & 47 & set.2007 & CPT-cv & pT1aNOMO & \\
\hline TIR76 & M & 27 & out.2007 & CPT-fv & pT1bNOM0 & \\
\hline TIR78 & $\mathrm{F}$ & 59 & mar.2006 & CPT-cv & pT3NOMO & (d) \\
\hline TIR79 & $\mathrm{F}$ & 45 & set.2007 & CPT-fv & pT1apN1bM0 & \\
\hline TIR80 & $\mathrm{F}$ & 53 & set.2009 & CPT-cV & pT1aNOMO & (d) \\
\hline TIR81 & $\mathrm{F}$ & 79 & nov.2006 & CPT-cv & pT3(m)NOMO & (d) \\
\hline TIR83 & M & 29 & mar.1999 & CPT-cv & $\mathrm{pT} 3(\mathrm{~m}) \mathrm{pN} 1 \mathrm{bM} 0$ & \\
\hline TIR84 & $\mathrm{F}$ & 25 & mai.2003 & CPT-cv & pT3(m)N0M0 & (d) \\
\hline TIR86 & $\mathrm{F}$ & 56 & jan.2003 & CPT-fv & pT3NOMO & \\
\hline
\end{tabular}




\subsection{Macro-dissecção}

A macro-dissecção foi realizada raspando-se a área tumoral e a área livre de tumor previamente identificadas por análise anátomo-patológica e por morfometria. As áreas raspadas foram previamente demarcadas nos cortes de 10um estendidos sobre uma lâmina. Para a demarcação das áreas seguiu-se como modelo um corte corado com H\&E. Em alguns casos a própria amostra estendida sobre lâmina foi corada com H\&E. Em resumo, os cortes foram deixados "overnight" a $56{ }^{\circ} \mathrm{C}$ para adesão do corte na lâmina. O material foi desparafinizado fazendo-se uma série de lavagens com xileno (2x por $2 \mathrm{~min}$ ) e etanol (100\% por $1 \mathrm{~min}, 96 \%$ por $1 \mathrm{~min}, 70 \%$ por 2 min). As lâminas foram mergulhadas em água gelada (6x) e incubadas por 2 min em hematoxilina gelada. Permaneceram por $1 \mathrm{~min}$ em água gelada e incubadas por $10 \mathrm{~s}$ em eosina y. As lâminas foram mergulhadas em etanol gelado (70\%, 96\% e $100 \%$, respectivamente) e secaram a temperatura ambiente. Logo em seguida, as áreas foram demarcadas e raspadas, e prosseguiu-se o procedimento de extração.

\subsection{Extração de DNA e detecção da mutação BRAF ${ }^{\mathrm{V} 600 \mathrm{E}}$ e mutações nos códons 12/13 e 61 do gene RAS por sequenciamento}

Para a extração de DNA total do material emblocado em parafina seguiu-se as instruções do kit de extração QIAamp® DNA FFPE Tissue (Qiagen, Frederick, MD, USA). Em resumo, foram feitos cortes de $10 \mu \mathrm{m}$ nos blocos de parafina. $O$ material foi desparafinizado fazendo-se uma série de lavagens com xileno e etanol. O material foi, então, submetido à digestão por protease rigorosa com tempo de incubação ótimo para a recuperação de DNA. O DNA foi purificado utilizando-se uma membrana acoplada à coluna proveniente no kit de extração.

Após a extração realizou-se PCR convencional em Mastercycler Gradient (Eppendorf, Hamburg, Germany) para detecção das mutações BRAFV600E (éxon 15), KRAS códon 12/13 e códon 61 (cromossomo 12). Em resumo, $2 \mu$ le DNA (300 ng) foram amplificados com 200 pmol de cada primer (Sigma-Aldrich, St. Louis, MO, USA), $200 \mu \mathrm{M}$ de deoxinucleotídeos trifosfato, 1×PCR Buffer, e 1,5 unidade de Hot Star Taq DNA Polymerase (Invitrogen, Life Technologies Corporation, Carlsbad, CA, USA) em um volume final de $50 \mu \mathrm{l}$. A PCR foi realizada. 
As condições experimentais da PCR foram: (1) para $B R A F^{V 600 E}$, primers senso 5'-TCATAATGCTTGCTCTGATAGGA-3' e anti-senso 5'GGCCAAAAATTTAATCAGTGGA-3' (Davies et al., 2002), com ciclagem a 94ํㅜ por 5 min (denaturação inicial), seguidas por 40 ciclos (denaturação a $94{ }^{\circ} \mathrm{C}$ por $45 \mathrm{~s}$, anelamento a $56{ }^{\circ} \mathrm{C}$ por $45 \mathrm{~s}$ e síntese a $72{ }^{\circ} \mathrm{C}$ por $\left.45 \mathrm{~s}\right)$, e extensão final em um único ciclo a $72 \stackrel{\circ}{\circ}$ por 5 min, (2) para KRAS códon 61, primers senso 5'GCACTGTAATAATCCAGACT-3' e anti-senso 5'-CATGGCATTAGCAAAGACTC-3' (Chang et al., 2009), com ciclagem a ciclagem a $94^{\circ} \mathrm{C}$ por 5 min (denaturação inicial), seguidas por 40 ciclos (denaturação a $94^{\circ} \mathrm{C}$ por $30 \mathrm{~s}$, anelamento a $53^{\circ} \mathrm{C}$ por $30 \mathrm{~s}$ e síntese a $72{ }^{\circ} \mathrm{C}$ por $1 \mathrm{~min}$ ), e extensão final em um único ciclo a $72{ }^{\circ} \mathrm{C}$ por 5 min, (3) para KRAS códon 12/13, primers senso 5'CCTTATGTGTGACATGTTCTAATATAG-3' e anti-senso 5'AGTAATATGCATATTAAAACAAGATTTACC-3' com a ciclagem a $94^{\circ} \mathrm{C}$ por 5 min (denaturação inicial), seguidas por 40 ciclos (denaturação a $94{ }^{\circ} \mathrm{C}$ por $30 \mathrm{~s}$, anelamento a $56{ }^{\circ} \mathrm{C}$ por $30 \mathrm{~s}$ e síntese a $72{ }^{\circ} \mathrm{C}$ por $1 \mathrm{~min}$ ), e extensão final em um único ciclo a $72^{\circ} \mathrm{C}$ por $5 \mathrm{~min}$.

O produto de amplificação foi avaliado em gel de agarose 2,0\% e purificado usando kit illustra GFX PCR DNA and Gel Band Purification (GE Healthcare, Piscataway, NJ, USA). O material passou por uma série de lavagens com tampão proveniente no kit e foi purificado utilizando-se membrana acoplada à coluna, segundo instruções do fabricante.

O produto purificado foi sequenciado em ambas as direções no $A B I 3500 X L$ (Life Technologies, Carlsbad, CA, USA), seguindo as instruções do kit BigDye Terminator v3 (Life Technologies). Em resumo, para a reação de cycle sequencing as amostras foram submetidas a $96{ }^{\circ} \mathrm{C}$ por $2 \mathrm{~min}, 96{ }^{\circ} \mathrm{C}$ por $45 \mathrm{~s}, 55^{\circ} \mathrm{C}$ por $30 \mathrm{~s}$, seguidas de 35 ciclos a $60{ }^{\circ} \mathrm{C}$ por $4 \mathrm{~min}$. Os primers utilizados foram os mesmos da PCR convencional. As amostras foram posteriormente precipitadas com EDTA e etanol, seguida de uma série de centrifugações. As amostras foram submetidas a 60 ${ }^{\circ} \mathrm{C}$ para evaporação do etanol residual, re-suspendidas em Formamida Hi-Di e desnaturadas a $95^{\circ} \mathrm{C}$ por $3 \mathrm{~min}$, seguida de incubação no gelo por $1 \mathrm{~min}$. O produto do sequenciamento foi analisado usando ABI PRISM 3500XL Genetic Analyser (Applied Biosystems, Life Technologies Corporation, Carlsbad, CA, USA), comparando-se as amostras com um controle positivo. A Figura 3 ilustra os 
resultados de sequenciamento para a mutação $B R A F^{V 600 E}$. A mesma estratégia é utilizada para a identificação das mutações em KRAS.

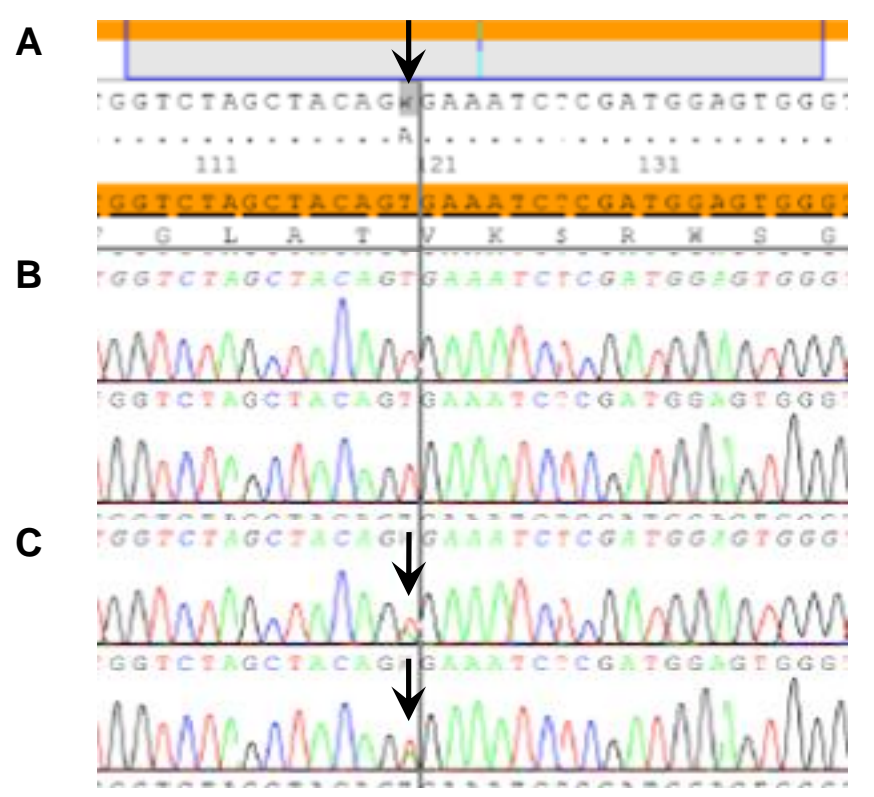

Figura 3: llustração do resultado de sequenciamento para $B R A F^{V 600 E}$. A: eletroferograma de uma amostra positiva para a mutação $B R A F^{V 600 E}$ usada como controle. B: eletroferograma representativo de uma amostra negativa para a mutação $B R A F^{V 600 E}$. C: eletroferograma representativo para uma amostra positiva para a mutação $B R A F^{V 600 E}$. Setas indicam a localização da mutação pontual.

\subsection{Detecção da mutação no gene BRAF ${ }^{\mathrm{V} 600 \mathrm{E}}$ por qRT-PCR}

A identificação da mutação $B R A F^{V 600 E}$ por qRT-PCR foi realizada com o kit TaqMan® Mutation Detection Assay Competitive Allele-Specific TaqMan® PCR (Applied Biosystems), seguindo as instruções do fabricante, em colaboração com o Laboratório Clínico do Hospital Israelita Albert Einstein. Cada reação utiliza um par de primers lócus específico e uma sonda TaqMan® marcada, um par de primers alelo-específico capaz de detectar a mutação e um oligonucleotídeo bloqueador que suprime o alelo normal. São realizados dois ensaios: um para a deteção dos alelos mutantes e um para a detecção dos alelos normais.

Resumidamente, o master mix contendo 1x TaqMan® Genotyping Master Mix, 1 x Exogenous IPC Template DNA, 1 x Exogenous IPC Mix e $60 \mathrm{ng}(2 \mu \mathrm{L})$ de DNA foi submetido à $95{ }^{\circ} \mathrm{C}$ por $10 \mathrm{~min}, 5$ ciclos de $92{ }^{\circ} \mathrm{C}$ por $15 \mathrm{~s}$ e $5{ }^{\circ} \mathrm{C}$ por $1 \mathrm{~min}$, e 40 ciclos a $92^{\circ} \mathrm{C}$ por $15 \mathrm{~s} \mathrm{e} 60^{\circ} \mathrm{C}$ por 1 min. A detecção da mutação é feita pelo cálculo 
de $\Delta \mathrm{C}_{\mathrm{T}}$ obtido da diferença entre os valores de $\mathrm{C}_{\mathrm{T}}$ dos alelos mutantes e dos alelos normais. Os valores de $\Delta \mathrm{C}_{\mathrm{T}}$ são comparados a uma amostra de referência.

\subsection{Detecção da mutação no gene BRAF ${ }^{\mathrm{V} 600 \mathrm{E}}$ por imuno-histoquímica}

A avaliação por imuno-histoquímica da proteína BRAF ${ }^{\mathrm{V} 600 \mathrm{E}}$ mutada foi realizada em colaboração com o Departamento de Patologia Geral do Instituto de Patologia Ruprecht-Karls-University Heidelberg (Heidelberg, Alemanha), segundo o protocol descrito por Koperek et al., 2012 (doi: 10.1097/PAS.0b013e318246b527).

Em resumo, foram extendidos cortes de $10 \mu \mathrm{m}$ sobre lâmina silanizada. As amostras foram submetidas a uma série de lavagens para retirada da parafina e incubadas com anti-corpo VE1 específico para BRAF ${ }^{\mathrm{V} 600 \mathrm{E}}$. Como controle foram utilizadas três amostras de melanomas (dois casos positivos para BRAF ${ }^{\mathrm{V} 600 \mathrm{E}}$ detectados por sequenciamento, com intensidade moderada e alta de expressão da proteína BRAF ${ }^{\mathrm{V} 600 \mathrm{E}}$; um caso negativo para $\mathrm{BRAF}^{\mathrm{V} 600 \mathrm{E}}$ e ausência de expressão da proteína $\mathrm{BRAF}^{\mathrm{V} 600 \mathrm{E}}$ ). Foram consideradas positivas para a mutação, amostras com imunorreação homogênea e distinta no citoplasma das células neoplásicas. Os resultados foram avaliados por dois patologistas.

\subsection{Extração de RNA}

Para a extração de RNA total do material emblocado em parafina e do material congelado seguiu-se as instruções do kit de extração RecoverAll ${ }^{\mathrm{TM}}$ Total Nucleic Acid Isolation (Ambion, Life Technologies Corporation, Carlsbad, CA, USA), ou do kit miRNeasy FFPE (Qiagen). Em resumo, foram feitos cortes de $10 \mu \mathrm{m}$ nos blocos de parafina. O material foi desparafinizado fazendo-se uma série de lavagens com xileno e etanol. O material fresco congelado foi previamente macerado com um morteiro, pistão e nitrogênio líquido. Ambos os materiais foram, então, submetidos à digestão por protease com tempo de incubação ótimo para a recuperação de RNA. O RNA foi purificado utilizando-se uma membrana acoplada à coluna proveniente no kit de extração e lavagens subsequentes. 


\subsection{Quantificação e avaliação da qualidade e da integridade do RNA}

A quantificação (concentração do RNA total) e a qualidade (pureza) do RNA total extraído das amostras foram realizadas por medições no espectrofotômetro NanoVue Spectrophotometer (GE Healthcare). A integridade do RNA foi avaliada em um Agilent 2100 Bioanalyzer utilizando o kit RNA 6000 LabChip.

\subsection{Detecção do rearranjo RET/PTC por PCR em tempo real}

A avaliação do rearranjo RET/PTC foi realizada no Departamento de Biologia Celular e do Desenvolvimento, Instituto de Ciências Biomédicas (ICB) da Universidade de São Paulo (USP), em colaboração com a Profa. Dra. Edna Kimura segundo o protocol descrito por Ricarte-Filho et al., 2009 (doi:10.1158/00085472.CAN-09-0727).

Em resumo, $100 \mathrm{ng}$ de RNA foram transcritos reversamente a cDNA com primer randômico - High Capacity cDNA RT kit (Applied Biosystems, Life Technologies Corporation). Em seguida, realizou-se uma PCR em tempo real para avaliar a expressão relativa da região dos éxon 10-11 e 12-13 de RET, que flanqueiam o rearranjo no íntron 11. Amostras com expressão de 12-13 > 10-11 foram avaliadas para recombinações específicas de RET, usando primers para RET/PTC1 e RET/PTC3. cDNA de linhagem TPC1 (RET/PTC1 positiva), e uma amostra de CPT expressando RET/PTC3 foram utilizados como controle. GAPDH foi usado como controle interno. O produto da PCR foi aplicado em gel de agarose $2 \%$.

\subsection{Síntese de cDNA e PCR em tempo real para detecção de miRNAs}

A partir de RNA total extraído foi efetuada a síntese de cDNA seguindo as instruções do kit de síntese TaqMan® MicroRNA Reverse Transcription (Applied Biosystems, Life Technologies Corporation). Os primers utilizados foram específicos para RNU44 (ID001094), RNU48 (ID001006), U6 (ID001973) 5S (AM30302), miR146a (ID00468), miR-146b (ID001097), miR-16 (ID00391), miR-19a (ID00395) miR21 (ID00397), miR-221 (ID000524) e miR-222 (ID002276) (Applied Biosystems, Life Technologies Corporation). A sequência madura e a localização gênica dos miRNAs utilizados segue na tabela abaixo (tabela 5). A síntese foi realizada no termociclador 
Eppendorf Mastercycler Gradient. Resumidamente, a reação de síntese foi incubada por 30 min a $16{ }^{\circ} \mathrm{C}$, seguida de aquecimento a $42^{\circ} \mathrm{C}$ por $30 \mathrm{~min}$, e $85^{\circ} \mathrm{C}$ por $5 \mathrm{~min}$.

Tabela 5: Sequência madura e localização gênica dos miRNAs utilizados (Fonte: miRBase versão 20 - junho 2013 - http://www.mirbase.org/)

\begin{tabular}{ccc}
\hline Gene & Sequência madura & Localização \\
\hline miR-146a & UGAGAACUGAAUUCCAUGGGUU & $5 q 34$ \\
miR-146b & UGAGAACUGAAUUCCAUAGGCU & 10q24.32b \\
miR-16 & UAGCAGCACGUAAAUAUUGGCG & $13 q 14$ \\
miR-21 & UAGCUUAUCAGACUGAUGUUGA & $17 q 23.2$ \\
miR-221 & AGCUACAUUGUCUGCUGGGUUUC & Xp11.3 \\
miR-222 & AGCUACAUCUGGCUACUGGGU & Xp11.3 \\
miR-19a & UGUGCAAAUCUAUGCAAAACUGA & $13 q 31.3$ \\
\hline
\end{tabular}

A PCR em tempo real foi realizada com kit TaqMan® Universal PCR Master Mix (Applied Biosystems, Life Technologies Corporation), seguindo instruções do fabricante, em um 7500 Real-Time PCR System (Applied Biosystems Inc. CA). As reações foram submetidas a $95{ }^{\circ} \mathrm{C}$ por $10 \mathrm{~min}$, seguidas por 45 ciclos a $95^{\circ} \mathrm{C}$ por 15 $\mathrm{s}$ e $60{ }^{\circ} \mathrm{C}$ por $1 \mathrm{~min}$. Os resultados foram normalizados com os resultados obtidos para os genes de expressão constante (RNAs nucleolares) permitindo corrigir alterações em relação à quantidade de material inicial na reação (VanGuilder et al., 2008). A quantificação relativa da expressão dos miRNAs foi realizada pelo método $2^{-\Delta \Delta C t}$ (Livak, Schmittgen, 2001).

\subsection{Avaliação da expressão global de miRNAs por microarranjos de DNA}

O ensaio de expressão global de miRNAs por microarranjos de DNA foi realizado com amostras parafinadas de 10 pacientes (Tabela 6). 
Tabela 6: Relação do pacientes selecionados para o ensaio de expressão global de miRNAs por microarranjos de DNA

\begin{tabular}{cc}
\hline \hline Pacientes & BRAFV600E \\
\hline TIR66 & Pos \\
TIR67 & Neg \\
TIR70 & Neg \\
TIR71 & Pos \\
TIR73 & Pos \\
TIR80 & Pos \\
TIR84 & Neg \\
TIR90A & Pos \\
TIR90B & Neg \\
TIR92 & Pos \\
\hline \hline
\end{tabular}

O ensaio foi realizado pela empresa Exiqon, na Dinamarca. Resumidamente as amostras foram marcadas utilizando o miRCURY LNA ${ }^{\text {TM }}$ microRNA Hi-Power Labeling Kit, Hy3 ${ }^{\mathrm{TM}} / \mathrm{Hy} 5^{\mathrm{TM}}$ com o fluoróforo $\mathrm{Hy} 3^{\mathrm{TM}}$, e hibridadas com miRCURY LNA $^{\mathrm{TM}}$ microRNA Array (v7), seguindo as intruções do fabricante (miRCURY LNA ${ }^{\mathrm{TM}}$ microRNA Array Kit, 7th generation, Exiqon A/S, Skelstedet, Denmark). Os slides contém sondas para captura de todos os miRNAs humanos depositadas no miRBase versão 18, controles positivos e negativos de hibridação, além de pequenos RNAs que podem ser usados como normalizadores para os níveis de expressão. Dentre os 2084 miRNAs presentes no microarranjo utilizado, nem todos apresentaram sinal positivo. A identificação daqueles com sinal suficiente para as análises subsequentes foi feita através de uma correção em função do "ruído de fundo", calculado a partir do sinal emitido pelos controles negativos. Foram calculados fold-changes (ou a razão entre a expressão de miRNAS) entre amostras positivas para a mutação em BRAF e negativas para a identificação de miRNAs considerados diferencialmente expressos entre os grupos.

\subsection{Análise estatística dos resultados de PCR em Tempo Real}

Para avaliar a diferença de expressão gênica entre amostras tumorais positivas para a mutação BRAF e amostras tumorais negativas para esta mutação foi realizado o teste não-paramétrico para amostras independentes de MannWhitney (GraphPad Prism ${ }^{\circledR}$ Software version 5.00). Considerou-se diferenças significativas quando $p<0.05$. 


\section{RESULTADOS}

\subsection{Seleção dos pacientes}

Neste estudo foram incluídos 51 pacientes com diagnóstico de carcinoma papilífero da glândula tireoide, todos tratados com tireoidectomia total. A maior parte dos pacientes eram do sexo feminino, ocorrendo na proporção 3,6:1 (mulher:homem). Trinta e cinco (68,6\%) amostras foram caracterizadas como variante clássica e dezesseis $(31,4 \%)$ correspondendo à variante folicular. $\mathrm{Na}$ ocasião do tratamento cirúrgico, 25 (49\%) pacientes tinham 45 anos ou menos. Dentre esses 25 pacientes, 10 (40\%) apresentaram metástases cervicais linfonodais confirmadas em exame anatomopatológico. Os outros dois pacientes que apresentaram metástases linfonodais tinham mais de 45 anos.

As características clínico-patológicas resumidas encontram-se na tabela 7.

Tabela 7: Características clínico-patológicas dos pacientes $(n=51)$ utilizados neste estudo.

\begin{tabular}{l||c} 
Características clinico-patológicas & $n(\%)$ \\
\hline Sexo & $11(21,6)$ \\
Masculino & $40(78,4)$ \\
Feminino & $46,5(22-79)$ \\
Idade média, em anos (variação) & \\
& \\
Recorrência & $32(62,7)$ \\
não & $19(37,3)$ \\
sim & \\
Estadiamento & \\
pT1 & $24(47,1)$ \\
pT2 & $2(3,9)$ \\
pT3 & $23(45,1)$ \\
pT4 & $2(3,9)$ \\
pN1 & $12(23,5)$
\end{tabular}

Foram encontradas dificuldades de contato e localização de alguns pacientes. Houve demora de alguns laboratórios de patologia na disponibilização dos blocos de parafina e das lâminas em H\&E. Para muitos casos, as lâminas tiveram de ser refeitas para a revisão anatomo-patológica. Em casos de tumores muito pequenos 
( $<1 \mathrm{~mm})$ inicialmente selecionados a revisão da lâmina mostrou ausência de neoplasia restante e o material teve de ser descartado.

\subsection{Características de amostras parafinadas e padronizações para análise de expressão gênica neste tipo de amostra}

A qualidade e a integridade do RNA extraído de amostras parafinadas foram avaliadas através de um ensaio eletroforético com o equipamento Bioanalyser e o ensaio específico RNA 6000 Pico Chip. Como controle do experimento foi utilizado material fresco extraído de uma linhagem celular (SCC25). A qualidade do RNA isolado da linhagem foi superior a do tecido emblocado em parafina, apresentando as primeiras duas bandas distintas de RNAr 18S e 28S, enquanto o RNA isolado de material parafinado resultou em bandas com baixo peso molecular, menor que 100 nucleotídeos (Figura 4).

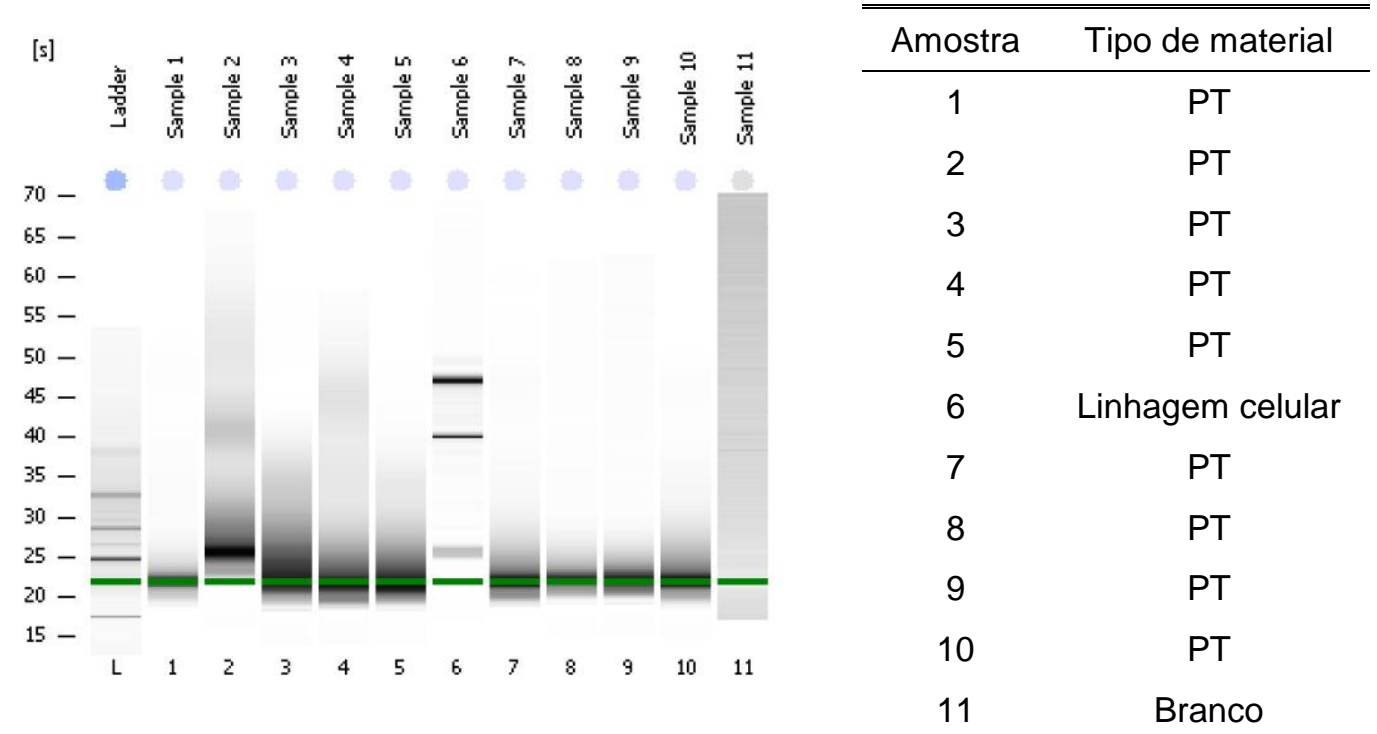

Figura 4: Avaliação da integridade do RNA total extraído de material parafinado de tireoide e de material fresco de uma linhagem celular (SCC25) através do ensaio Agilent RNA 6000 Pico chip no equipamento Bioanalyser. PT: tecido parafinado tumoral. L: padrão de peso molecular do kit Agilent RNA 6000 Pico chip. O material parafinado apresenta degradação do RNA (apenas um smear é visualizado após corrida), o que não foi observado para a linhagem celular (bandas $18 \mathrm{~S}$ e $28 \mathrm{~S}$ claras e não há smear).

Para avaliar a quantidade de RNA total inicial na reação de síntese de cDNA e a eficiência dos primers de miRNAs, foram utilizadas as quantidades de $10 \mathrm{ng} e$ 
50ng de RNA total de amostras de tireoide emblocadas em parafina para a síntese de cDNA e avaliamos a expressão detectada para 3 miRNAs e para dois genes de expressão constitutiva passíveis de serem utilizados para normalização das reações (RNU44 e RNU48). Os resultados mostraram eficiências próximas de 100\% para todos os miRNAs selecionados, bem como para os genes RNU44 e RNU48, mostrando ser possível utilizar valores intermediários entre 10ng e 50ng de RNA total inicial para a síntese de cDNA (Figura 5).
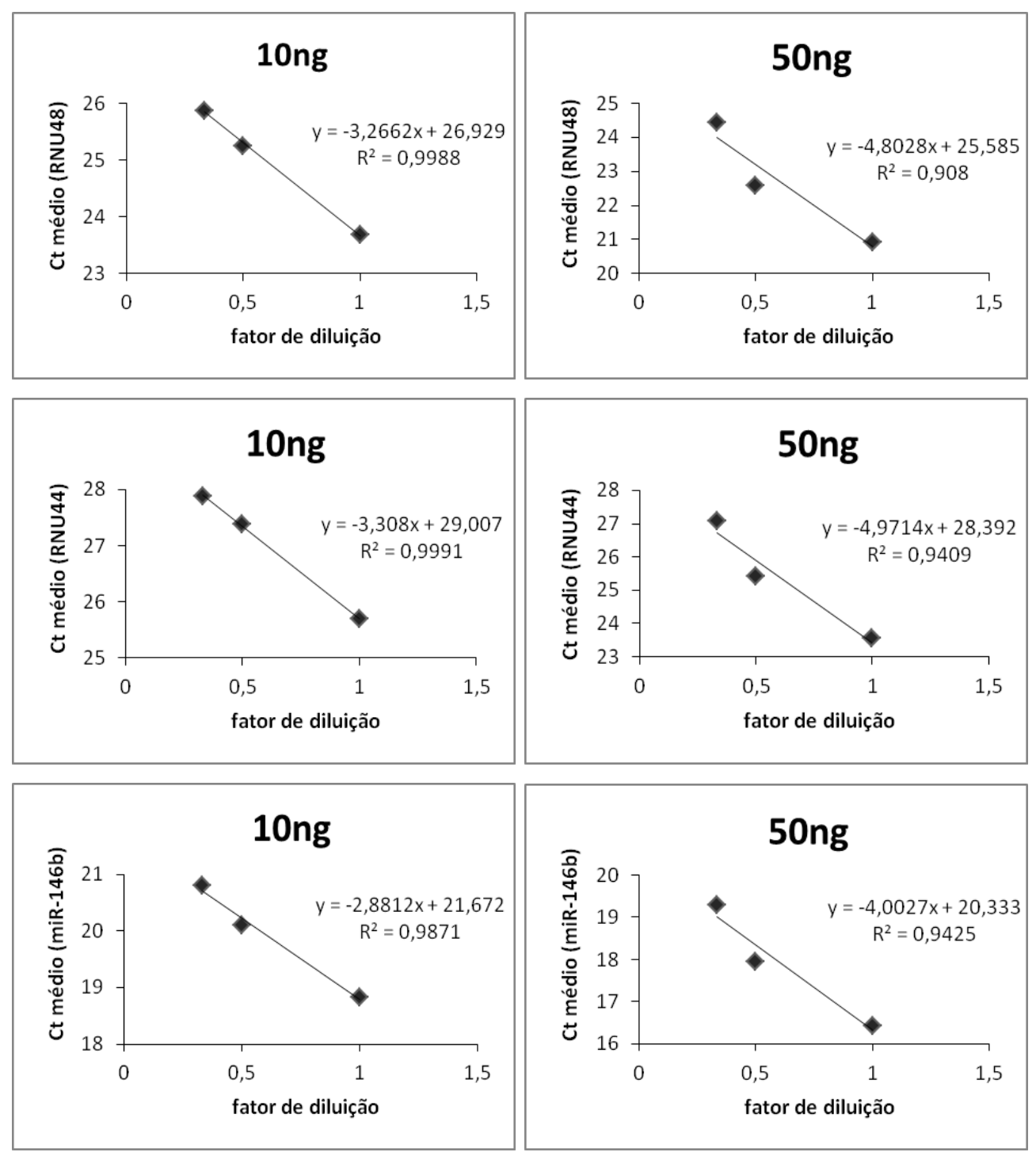

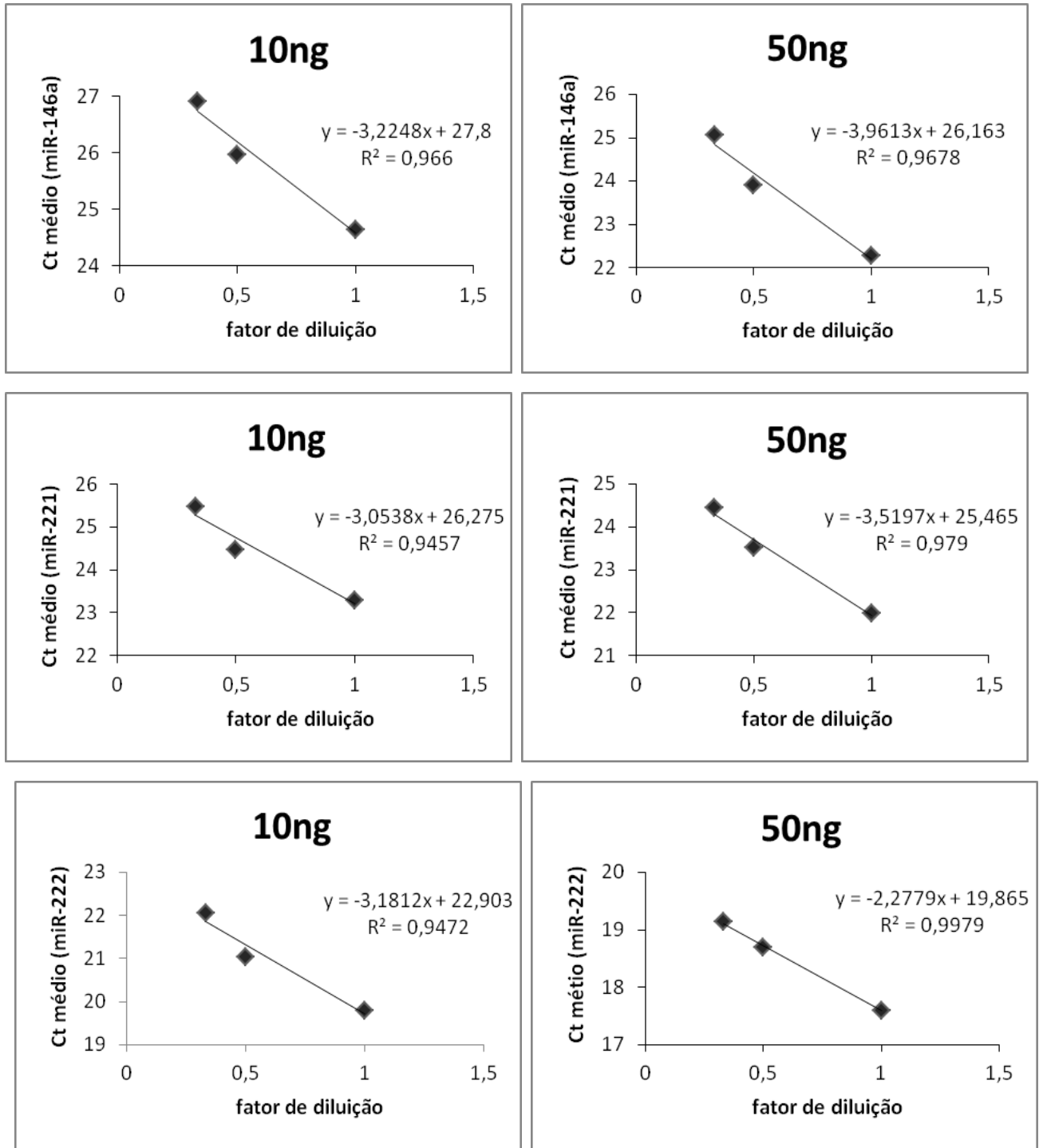

Figura 5: Avaliação das quantidades iniciais de RNA para análise de expressão gênica de miRNAs e eficiência dos primers (RNU44, RNU48, miR-146a, miR-146b, miR-221 e miR222). Os gráficos indicam eficiência próxima de $100 \%$ para todos os primers e valores entre 10ng e 50ng de RNA total inicial para a síntese de cDNA.

A técnica de PCR em tempo real requer a utilização de genes de expressão constitutiva (controles endógenos) para normalização dos resultados de expressão. A normalização permite corrigir variações na quantidade de RNA total inicial na reação ou variações na eficiência da transcrição reversa. Para selecionar os controles endógenos (de expressão constitutiva), avaliamos a expressão do RNU44, e RNU48 em 7 amostras de tireoide emblocadas em parafina. Todos são RNA nucleolares que apresentam características similares aos miRNAs quanto ao tamanho. 
Os resultados mostraram que todos os controles endógenos apresentaram expressão estável e comparável entre as amostras avaliadas. A figura 6 ilustra os resultados para o RNU44 e RNU48.
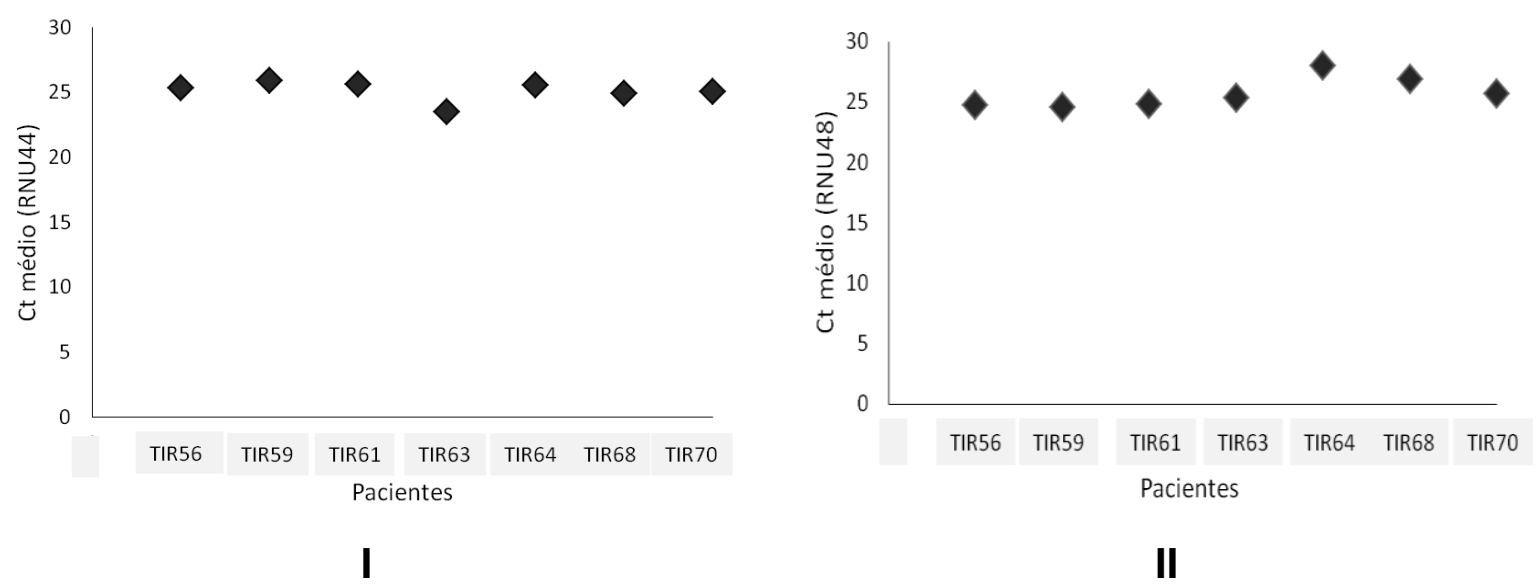

Figura 6: llustração do resultado de expressão do gene constitutivo (I) RNU44 e (II) RNU48 em 7 amostras de tireoide não macro-dissecadas. Baixa variação entre os valores de Ct médio entre as amostras indica expressão estável do controle endógeno.

Para avaliar a eficiência da extração de miRNAs de material parafinado em comparação com o que obteríamos de material fresco, selecionamos o miR-146b, e comparamos a sua expressão em 5 pacientes (TIR1, TIR2, TIR4, TIR5, TIR6), contendo cada um, uma amostra de tecido congelado de tumor, uma amostra de tecido congelado de borda livre de tumor, e uma amostra de tecido tumoral emblocada em parafina, totalizando 15 amostras (Tabela 4 em Métodos). Os valores de expressão de miR-146b foram normalizados com o valor de expressão de RNAr $5 S$.

Os resultados da PCR em Tempo Real mostraram que os níveis de expressão do miR-146b foram significativamente maiores nas amostras de CPT congeladas e nos tecidos de CPT fixados em parafina do que nas amostras pareadas congeladas e livres de tumor $(p<0,05)$ (Figura 7). Além disso, não foi observada diferença entre os níveis de expressão quando comparadas as amostras congeladas e as amostras fixadas em parafina $(p>0,05)$. 


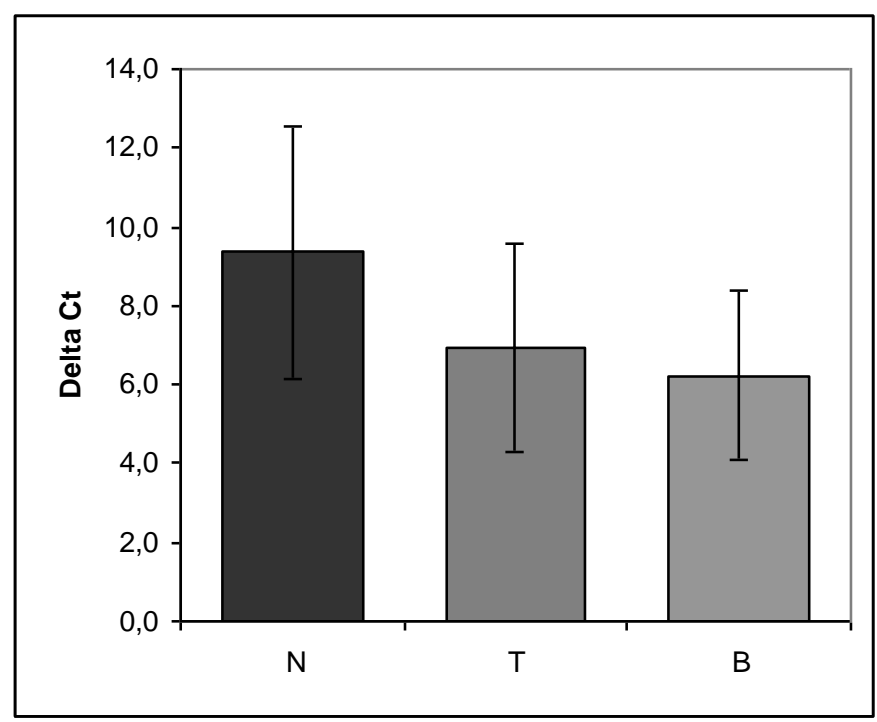

Figura 7: Histograma para a expressão do gene miR-146b em amostras pareadas congeladas e emblocadas em parafina. Média e desvio padrão dos valores de expressão normalizados para o gene miR-146b em amostras congeladas livres de tumor $(\mathrm{N})$, tumorais $(\mathrm{T})$ e amostras tumorais fixadas em parafina (B). Uma diferença significativa foi observada entre $\mathrm{N}$ e $\mathrm{T}$, e entre $\mathrm{N}$ e B, mas não entre $\mathrm{T}$ e $\mathrm{B}$.

Tendo em vista que a heterogeneidade do material parafinado pode interferir na expressão gênica final constatada, o segundo passo foi avaliar a expressão do miR-146b em um grupo de amostras heterogêneo quanto à quantidade de tumor emblocada. Foram selecionadas, aleatoriamente, 9 amostras de CPT (TIR48, TIR54, TIR56, TIR57, TIR58, TIR59, TIR60, TIR61, TIR62) e 1 amostra não tumoral, de forma não pareada (Tabela 4 em métodos).

Nossos resultados mostraram não haver variação significativa entre os valores de expressão nas amostras tumorais e das amostras livres de tumor quando agrupadas ( $p$ >0.05). Para uma melhor compreensão deste resultado, analisamos a quantidade de tumor presente nos cortes utilizados, através da técnica de morfometria.

As amostras apresentaram grande variabilidade quanto à área total emblocada e porcentagem de tumor. A porcentagem de tumor variou de 4,43 $83,48 \%$ entre as 9 amostras de CPT analisadas, além de apresentarem outros tipos de tecidos associados ao tumor (tabela 8). 
Tabela 8: Características das amostras acessadas partir da técnica de morfometria.

\begin{tabular}{|c|c|c|c|}
\hline Pacientes & $\begin{array}{l}\text { Porcentagem de } \\
\text { células tumorais } \\
\qquad(\%)\end{array}$ & $\begin{array}{l}\text { Área } \\
\text { total } \\
\left(\mathrm{mm}^{2}\right)\end{array}$ & Condições associadas \\
\hline TIR48 & 6,32 & 34,28 & - \\
\hline TIR54 & 4,43 & 201,88 & $\begin{array}{l}\text { Fibrose intratumoral leve; tireoidite } \\
\text { acentudada. }\end{array}$ \\
\hline TIR56 & 13,79 & 178,80 & $\begin{array}{l}\text { Inflamação peritumoral leve; fibrose } \\
\text { peritumoral leve; corpos psamomatosos. }\end{array}$ \\
\hline TIR57 & 13,02 & 115,99 & $\begin{array}{l}\text { Inflamação intratumoral moderada; fibrose } \\
\text { intratumoral moderada. }\end{array}$ \\
\hline TIR58 & 83,48 & 214,47 & $\begin{array}{l}\text { Inflamação peritumoral leve; fibrose leve } \\
\text { peri e intratumoral. }\end{array}$ \\
\hline TIR59 & 79,76 & 198,56 & $\begin{array}{l}\text { Fibrose intratumoral leve; corpos } \\
\text { psamomatosos; nódulo adenomatoso } \\
\text { associado. }\end{array}$ \\
\hline TIR60 & 14,82 & 211,71 & $\begin{array}{l}\text { Inflamação peritumoral leve; fibrose } \\
\text { peritumoral leve; nódulo adenomatoso } \\
\text { associado. }\end{array}$ \\
\hline TIR61 & 75,74 & 205,44 & $\begin{array}{l}\text { Inflamação peritumoral leve; fibrose } \\
\text { intratumoral acentuada; nódulo } \\
\text { adenomatoso associado. }\end{array}$ \\
\hline TIR62 & 55,24 & 376,92 & Fibrose moderada peri e intratumoral \\
\hline
\end{tabular}

Quando a expressão do miR-146b foi avaliada em cada uma das amostras contendo tecido tumoral, individualmente, comparando-as com uma amostra livre de tumor, constatamos variabilidade de expressão (Figura 8). 


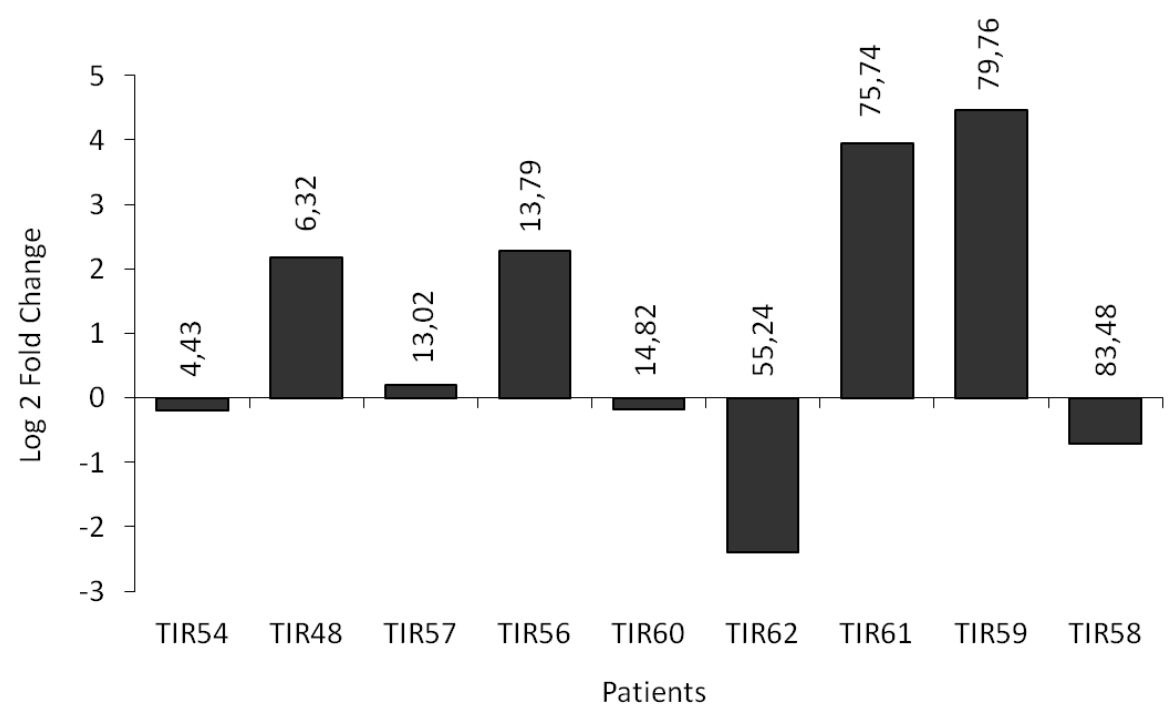

Figura 8: Expressão relativa do miR-146b em 9 amostras de CPT comparadas com a expressão de uma amostra livre de tumor. Eixo $x$ indica cada um dos pacientes analisados. Eixo y apresenta a expressão relativa expressa em $\log _{2}$ do fold change. Valores acima de zero indicam maior expressão na amostra tumoral. $\mathrm{Na}$ vertical estão os valores correspondentes à porcentagem de células neoplásicas em cada uma das amostras.

Os pacientes TIR48, TIR56, TIR61 e TIR59 apresentaram níveis de expressão elevados para o miR-146b. Entre entanto, nem todas as amostras apresentam maior expressão para esse miRNA. Mesmo em amostras com porcentagem de tumor significativa e quantidade boa de material emblocado, a expressão gênica nem sempre é comparável. Como exemplo, podem ser citadas as amostras TIR59 e TIR61, com resultados semelhantes de expressão e de quantidade de tecido tumoral na amostra. No entanto, o mesmo não pode ser dito quando, a estas amostras, são comparados os pacientes TIR62 e TIR58, ambos apresentando quantidade significativa de tumor (acima de 50\%), porém com valores de expressão bastante inferiores.

Para avaliar o impacto da porcentagem de células tumorais na expressão gênica, macro-dissecamos as 5 amostras do ensaio anterior (TIR54, TIR57, TIR58, TIR60, TIR62) que não haviam apresentado maior expressão do miR-146b, reduzindo consideravelmente o número de células livres de tumor presentes no tecido adjacente. Os níveis de expressão deste miRNA foram comparados entre o tecido tumoral e o tecido de margem tumoral livre de tumor, de forma pareada. 
Na macro-dissecção utiliza-se, geralmente, uma lâmina corada em H\&E como referência para localização da área tumoral (figura 9). Usamos, neste ensaio, a coloração de H\&E para facilitar a identificação das áreas de interesse. Selecionamos 7 amostras para avaliar a influência da coloração na expressão gênica, e comparamos a expressão do controle endógeno RNU48 na presença e na ausência de coloração.

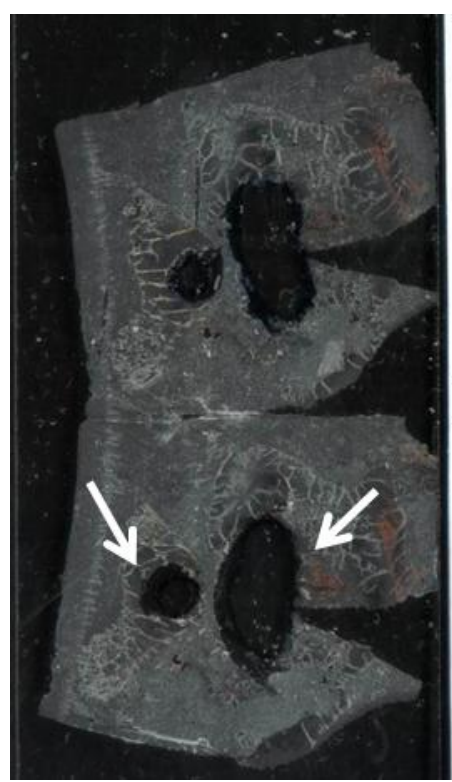

A

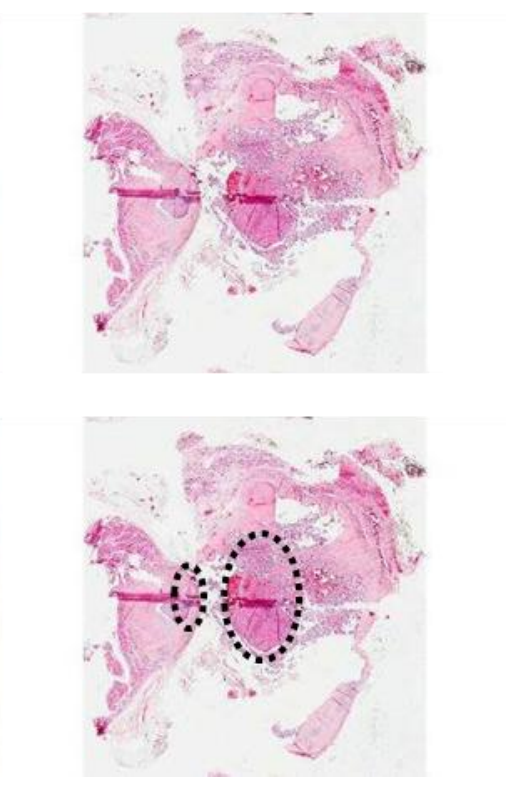

B

Figura 9: Ilustração do material utilizado para a extração de RNA. A: corte sem a coloração. Setas indicam as áreas raspadas. B: corte corado com H\&E. Áreas pontilhadas indicam a localização do tumor.

Os resultados mostraram estabilidade nos valores de expressão do controle endógeno em todas as amostras. Quando comparados à expressão do RNU48 em amostras sem a coloração, não observamos diferenças de expressão entre elas (Figura 10). 


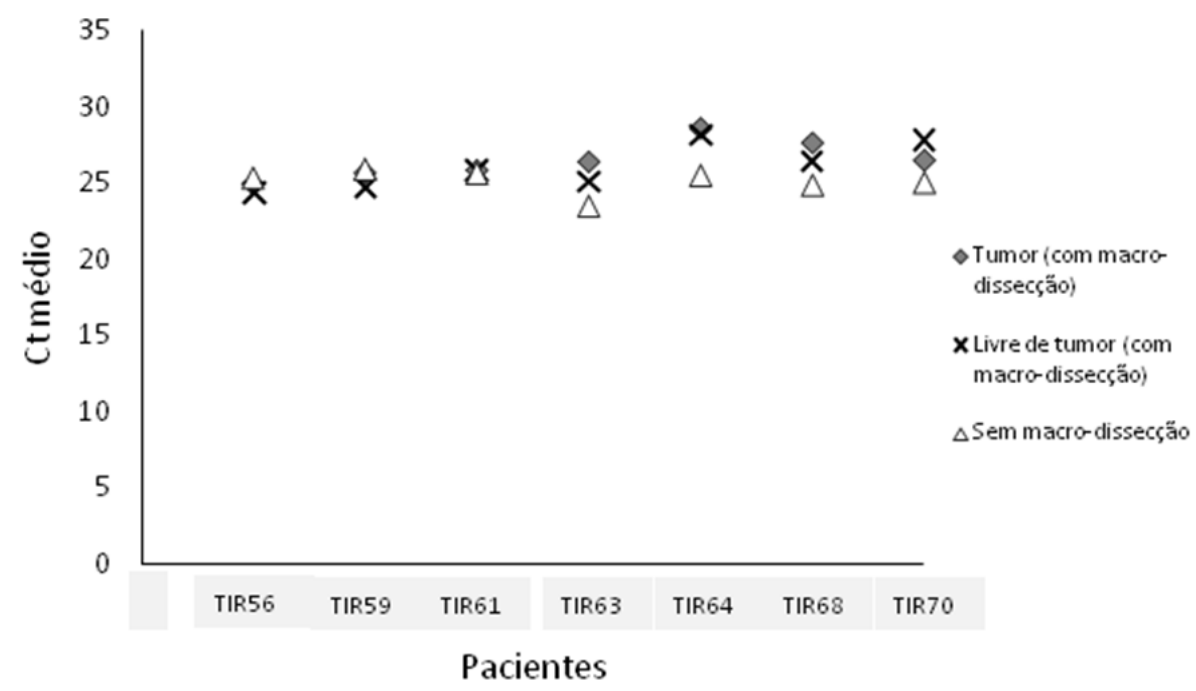

Figura 10: llustração do resultado de expressão do gene constitutivo RNU48 em amostras de tireoide macro-dissecadas (tumor e borda tumoral livre de tumor) após coloração com H\&E. Os valores de Ct médio obtidos se assemelham aos resultados obtidos para as mesmas amostras sem a coloração (não macro-dissecadas).

Das 5 amostras avaliadas (TIR54, TIR57, TIR58, TIR60, TIR62) observamos maior expressão do miR-146b, exceto para o paciente TIR54 (Figura 11). 
miR-146b

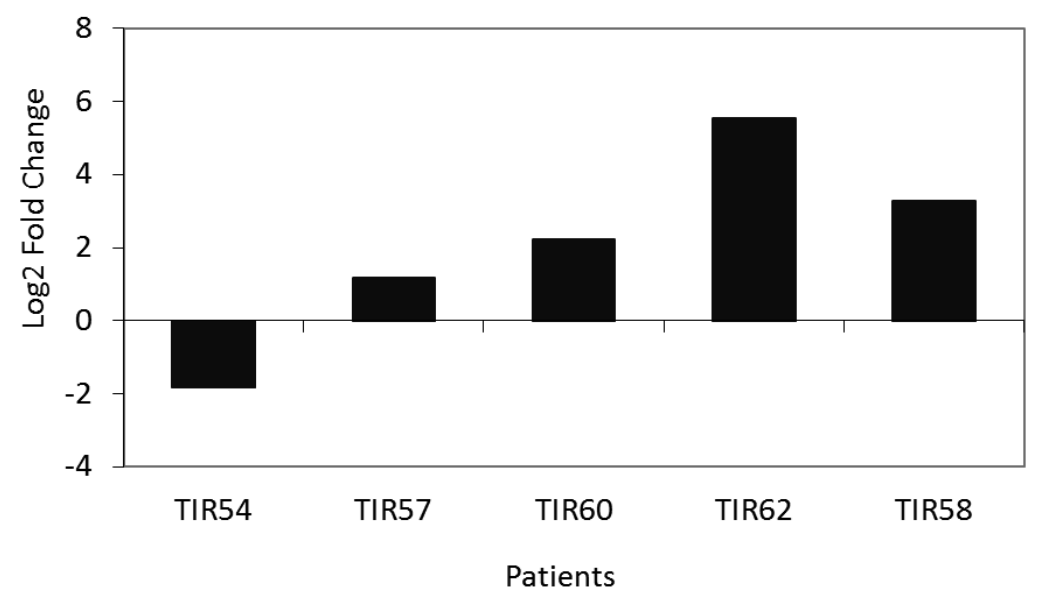

Figura 11: Expressão relativa do miR-146b em 5 amostras de CPT macro-dissecadas comparada com a borda tumoral livre de tumor, de forma pareada. Com exceção do TIR54, o miR-146b mostrou-se mais expresso nas amostras de CPT. Eixo $x$ indica cada um dos pacientes analisados. Eixo $y$ apresenta a expressão relativa expressa em $\log _{2}$ do fold change. Valores acima de zero indicam maior expressão na amostra tumoral.

A análise morfométrica do paciente TIR54 mostrou significativa infiltração inflamatória no tecido peritumoral.

Para avaliar se a presença de infiltrados inflamatórios é capaz de interferir na expressão do miR-146b, selecionamos outras 3 amostras apresentando essa condição associada (TIR65, TIR72 e TIR73) (Figura 12). 
A

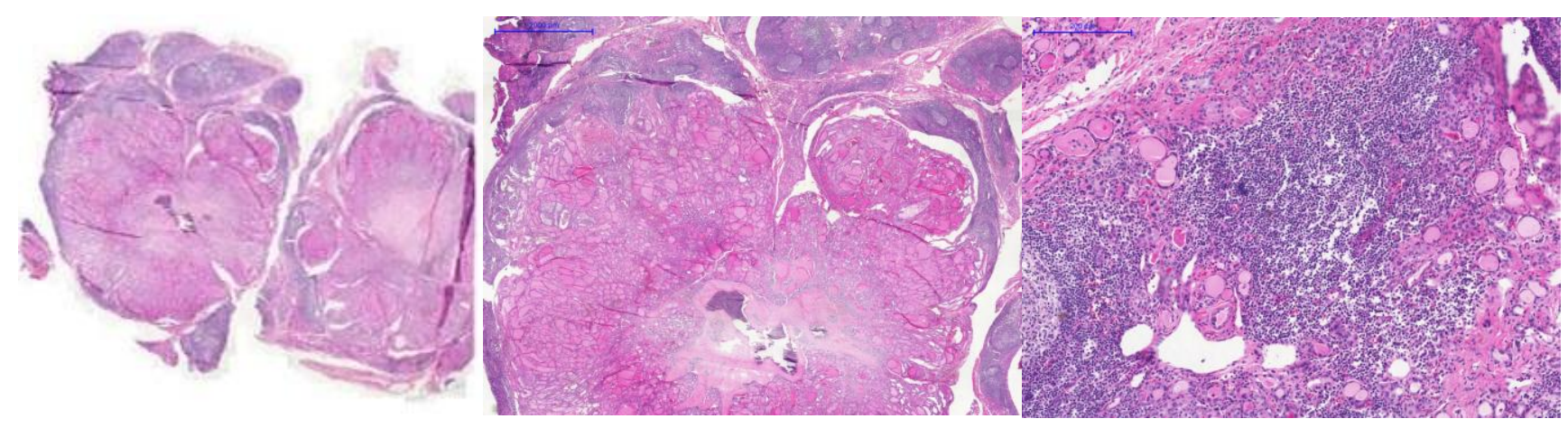

B

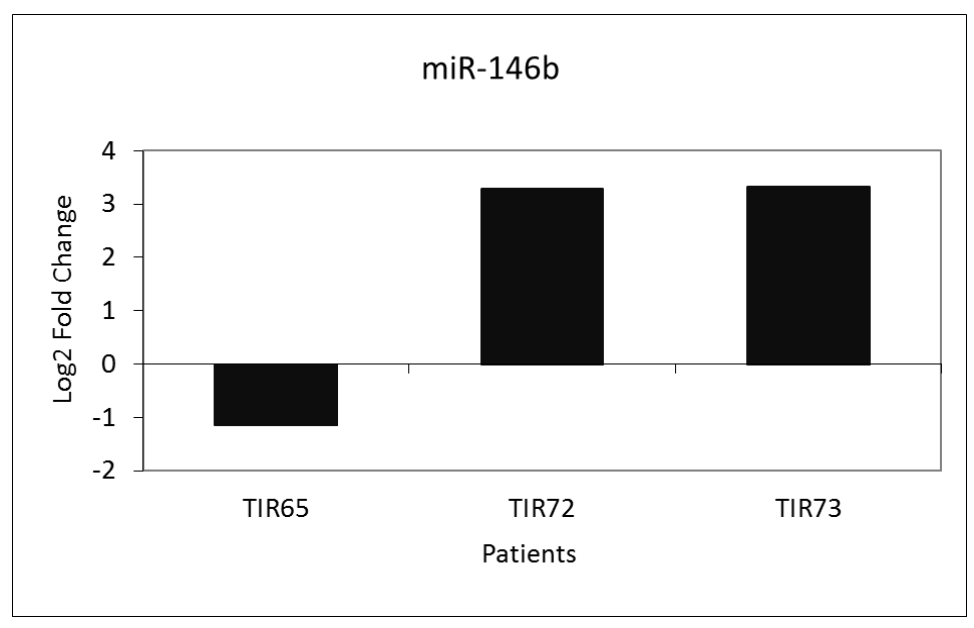

Figure 12: A: Amostra de CPT (TIR65) em diversos aumentos, mostrando a presença de infiltrados inflamatórios na região peritumoral. Da esquerda para a direita: imagem sem ampliação escaneada no Pannoramic 250 Flash II (3DHISTECH); barra de aumento correspondendo a $2000 \mu \mathrm{m}$; barra de aumento correspondendo a $200 \mu \mathrm{m}$. B: Expressão relativa do miR-146b em 3 amostras de CPT macro-dissecadas comparada com a borda tumoral livre de tumor, de forma pareada. As amostras apresentavam como condição associada infiltrados inflamatórios. Com exceção do TIR65, o miR-146b mostrou-se mais expresso nas amostras de CPT. Eixo $x$ indica cada um dos pacientes analisados. Eixo $y$ apresenta a expressão relativa expressa em $\log _{2}$ do fold change. Valores acima de zero indicam maior expressão na amostra tumoral.

Apesar das condições associadas serem semelhantes, apenas uma dessas amostras (TIR65) apresentou o mesmo resultado de expressão que o paciente TIR54.

Para melhor compreender o impacto da porcentagem de tumor e da quantidade de tecido livre de tumor na expressão gênica em amostras parafinadas, selecionamos os pacientes TIR56, TIR59 e TIR61, avaliados acima, e quatro 
pacientes adicionais (TIR63, TIR64, TIR68 e TIR70) para avaliar a expressão do miR-146b. Os pacientes apresentavam 2 blocos de material emblocado em parafina com diferentes porcentagens de tumor e 2 blocos livres de tumor. Um total de 28 amostras (14 amostras contento tumor e 14 amostras totalmente livres de tumor) foi analisado.

As características de cada amostra, as porcentagens de tumor e as condições associadas encontram-se na tabela 9.

Tabela 9: Características das amostras de cada um dos 7 pacientes. Destacamos as condições associadas descritas no laudo anatomo-patológico.

\begin{tabular}{|c|c|c|c|c|}
\hline Paciente & $\begin{array}{l}\text { Identificação } \\
\text { do bloco }\end{array}$ & $\begin{array}{l}\text { Porcentagem } \\
\text { de células } \\
\text { tumorais }(\%)\end{array}$ & $\begin{array}{l}\text { Característica } \\
\text { da amostra }\end{array}$ & Condições associadas \\
\hline \multirow[t]{4}{*}{ TIR56 } & B1 & 1,43 & CPT & $\begin{array}{l}\text { Fibrose peritumoral leve; corpos } \\
\text { psamomatosos. }\end{array}$ \\
\hline & B2 & 13,79 & СРТ & Tireoidite leve; fibrose peritumoral leve. \\
\hline & L1 & & $\begin{array}{l}\text { Livre de } \\
\text { tumor }\end{array}$ & Bócio associado. \\
\hline & L2 & & $\begin{array}{l}\text { Livre de } \\
\text { tumor }\end{array}$ & Tireoidite. \\
\hline \multirow[t]{4}{*}{ TIR59 } & B1 & 37,71 & CPT & Embolia tumoral vascular. \\
\hline & B2 & 73,54 & СРТ & $\begin{array}{l}\text { Fibrose intratumoral leve; corpos } \\
\text { psamomatosos. }\end{array}$ \\
\hline & L1 & & $\begin{array}{l}\text { Livre de } \\
\text { tumor }\end{array}$ & - \\
\hline & L2 & & $\begin{array}{l}\text { Livre de } \\
\text { tumor }\end{array}$ & Tireoidite focal leve; bócio associado. \\
\hline \multirow[t]{4}{*}{ TIR61 } & B1 & 5,56 & СРТ & Fibrose leve intratumoral. \\
\hline & B2 & 24,21 & CPT & $\begin{array}{l}\text { Fibrose acentuada intratumoral; apresenta } \\
\text { um fragmento livre de tumor com bócio } \\
\text { associado e tireoidite leve. }\end{array}$ \\
\hline & L1 & & $\begin{array}{l}\text { Livre de } \\
\text { tumor }\end{array}$ & Bócio associado. \\
\hline & L2 & & $\begin{array}{l}\text { Livre de } \\
\text { tumor }\end{array}$ & - \\
\hline \multirow[t]{4}{*}{ TIR63 } & B1 & 2,65 & CPT & $\begin{array}{l}\text { Infiltrado leve; tireoidite leve; fibrose } \\
\text { peritumoral leve; presença de um linfonodo } \\
\text { livre de tumor. }\end{array}$ \\
\hline & B2 & 18,30 & CPT & $\begin{array}{l}\text { Infiltrado leve intra e peritumoral; } \\
\text { fibrosemoderada intratumoral; corpos } \\
\text { psamomatosos; calcificação intratumoral. }\end{array}$ \\
\hline & L1 & & $\begin{array}{l}\text { Livre de } \\
\text { tumor }\end{array}$ & Tireoidite leve. \\
\hline & L2 & & Livre de & Tireoidite leve. \\
\hline
\end{tabular}




\begin{tabular}{|c|c|c|c|c|}
\hline \multirow[t]{4}{*}{ TIR64 } & B1 & 4,97 & СРT & Tumor está dentro do vaso \\
\hline & B2 & 69,08 & СРТ & $\begin{array}{l}\text { Presenças de corpos psamomatosos; } \\
\text { fibrose moderada intratumoral. }\end{array}$ \\
\hline & L1 & & $\begin{array}{l}\text { Livre de } \\
\text { tumor }\end{array}$ & Bócio associado. \\
\hline & L2 & & $\begin{array}{l}\text { Livre de } \\
\text { tumor }\end{array}$ & - \\
\hline \multirow[t]{4}{*}{ TIR68 } & B1 & 15,54 & СРТ & - \\
\hline & B2 & 29,97 & СРТ & Fibrose acentuada intratumoral. \\
\hline & L1 & & $\begin{array}{l}\text { Livre de } \\
\text { tumor }\end{array}$ & - \\
\hline & L2 & & $\begin{array}{l}\text { Livre de } \\
\text { tumor }\end{array}$ & - \\
\hline \multirow[t]{4}{*}{ TIR70 } & B1 & 4,44 & СРТ & Fibrose acentuada intratumoral. \\
\hline & B2 & 79,94 & СРТ & Fibrose leve intratumoral. \\
\hline & L1 & & $\begin{array}{l}\text { Livre de } \\
\text { tumor }\end{array}$ & - \\
\hline & L2 & & $\begin{array}{l}\text { Livre de } \\
\text { tumor }\end{array}$ & - \\
\hline
\end{tabular}

Os resultados mostraram que a expressão do miR-146b corresponde à porcentagem de tumor quando um paciente é avaliado individualmente. No entanto, a intensidade dos níveis de expressão varia entre os pacientes (Figura 13). Por exemplo, o TIR61 apresenta baixas porcentagens de tumor (até 25\%) e apresenta níveis de expressão do miR-146b semelhantes ao TIR59, TIR64 e TIR70, contendo pelo menos $\sim 70 \%$ de tumor. 


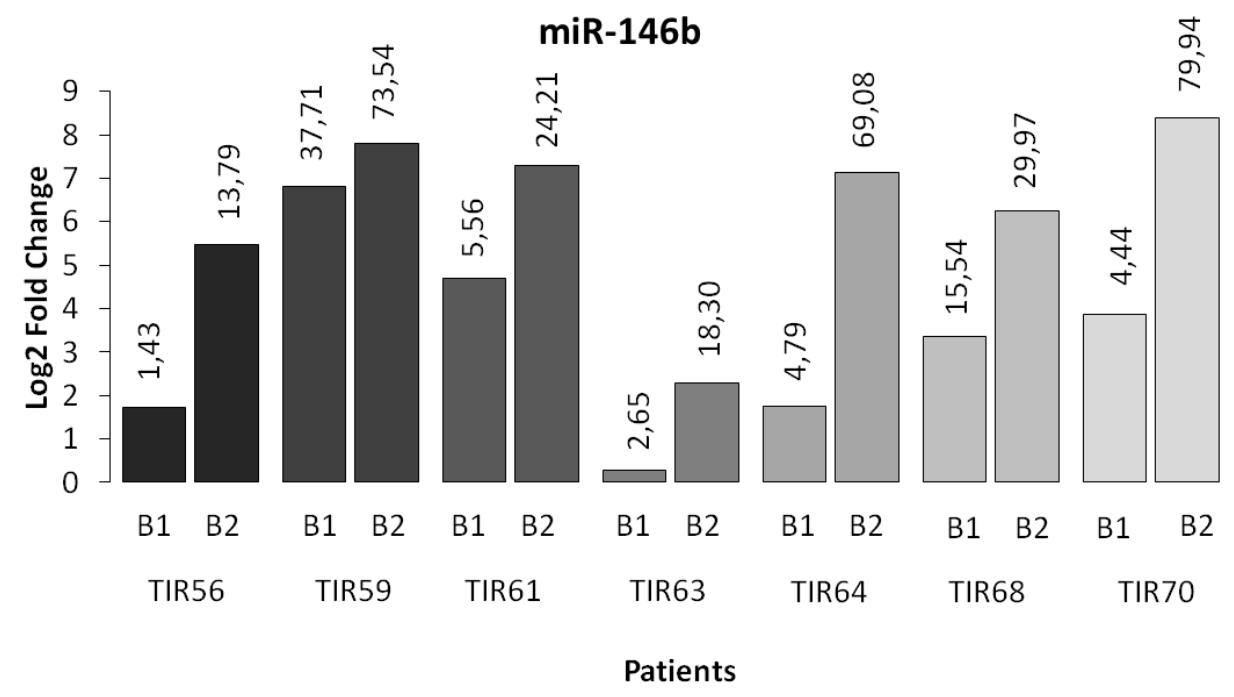

Figura 13: Histograma para a expressão do miR-146b em um painel de amostras de pacientes diagnosticados com carcinoma papilífero de tireoide. Valores de fold change foram obtidos comparando-se as amostras tumorais com o valor médio de expressão das amostras livres de tumor, de forma pareada. Eixo $x$ indica cada um dos pacientes analisados. Eixo y apresenta a expressão relativa expressa em $\log _{2}$ do fold change. Valores acima de zero indicam maior expressão na amostra tumoral. Na vertical estão os valores correspondentes à porcentagem de células neoplásicas em cada uma das amostras.

Para confirmar esses resultados, selecionamos os miRNAs miR-221 e miR222 (Tabela 3). Os resultados foram semelhantes aos observados para o miR-146b (Figura 14), evidenciando a variação na expressão desses 3 miRNAs nas áreas livre de tumor e nos níveis de expressão individuais de cada paciente. 
A

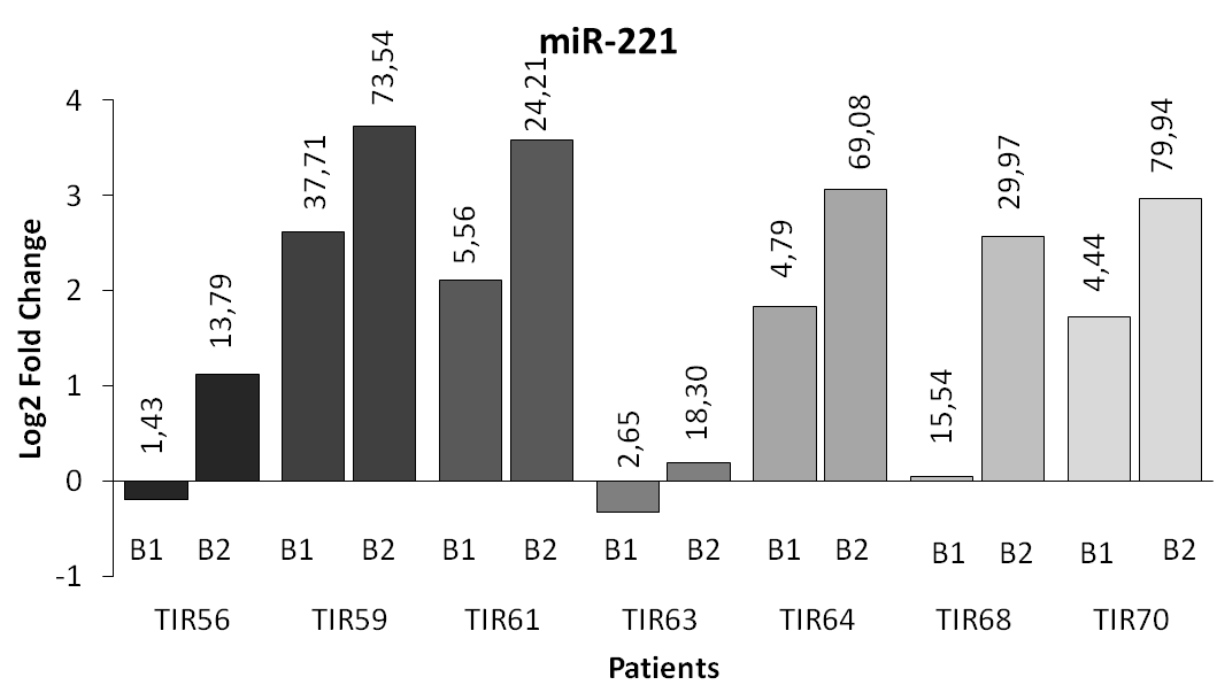

B miR-222

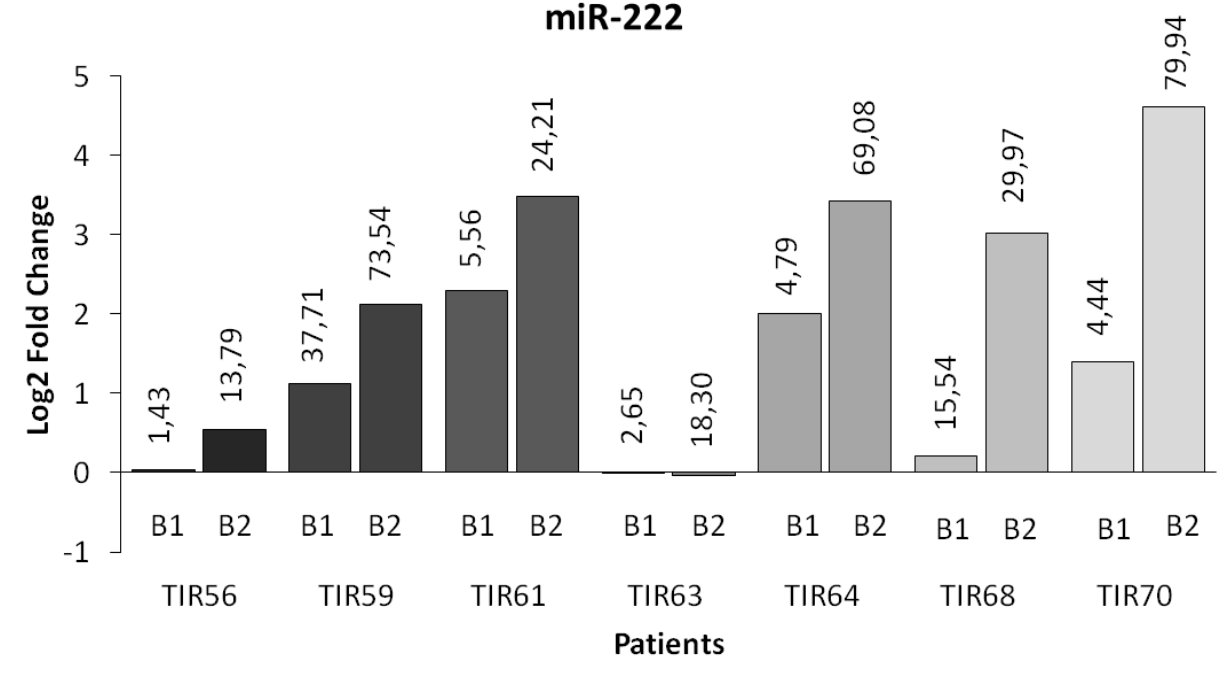

Figura 14: Histograma para a expressão do miR-221 (A) e miR-222 (B) em um painel de amostras de pacientes diagnosticados com carcinoma papilífero de tireoide. Valores de fold change foram obtidos comparando-se as amostras tumorais com 0 valor médio de expressão das amostras livres de tumor, de forma pareada. Eixo $x$ indica cada um dos pacientes analisados. Eixo $y$ apresenta a expressão relativa expressa em $\log _{2}$ do fold change. Valores acima de zero indicam maior expressão na amostra tumoral. Na vertical estão os valores correspondentes à porcentagem de células neoplásicas em cada uma das amostras.

\subsection{Detecção de mutações frequentes em CPT: BRAF, RET-CPT, RAS}

4.3.1 Avaliação da qualidade do DNA extraído para fins de sequenciamento 
Para avaliar a qualidade da extração de DNA, foram selecionadas amostras de tireoide emblocadas em parafina de 5 pacientes (Tabela 4) e optamos pelo sequenciamento por Sanger do fragmento que inclui $B R A F^{V 600 E}$ para avaliar a extração. O método de Sanger é uma das técnicas mais bem estabelecidas no meio científico para a detecção de mutações.

Para as 5 amostras avaliadas não foram observados problemas de amplificação. Os fragmentos amplificados correspondiam ao tamanho esperado de $249 \mathrm{pb}$.

No entanto, quando mais amostras foram avaliadas, nem todas amplificaram após a PCR convencional. Mesmo após aumentada a quantidade de material de partida, algumas amostras não foram amplificadas com sucesso (Figura 15).

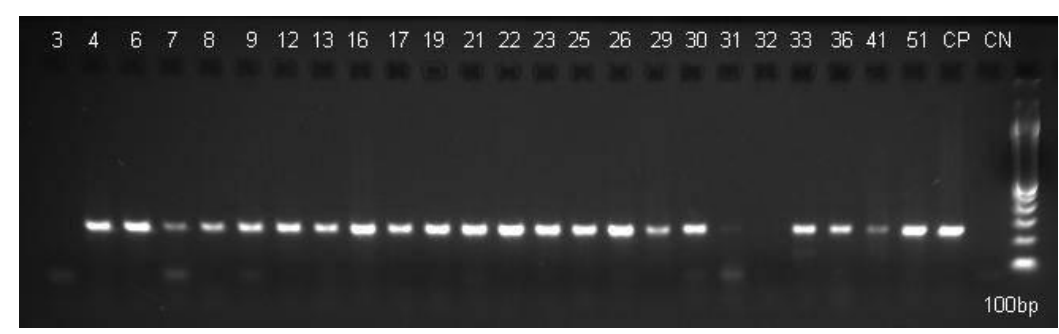

Figura 15: Gel de agarose $2 \%$ comparando as bandas formadas pelas amostras e pelo controle positivo (CP) - amostra de sangue de uma paciente positivo para a mutação - após realizada uma PCR para amplificação da região de interesse do gene BRAF. Um marcador de massa molecular de 100pb (Invitrogen ${ }^{\mathrm{TM}}$ ) foi utilizado para avaliar o tamanho das bandas. As amostras 3 e 32 (pacientes TIR48 e TIR87, respectivamente) não amplificaram. $\mathrm{CN}$ : controle negativo.

Para contornar o problema, adicionou-se à PCR convencional a Q-Solution (Qiagen), que é um aditivo que facilita o anelamento entre o primer e seu template, aumentando sua especificidade (QIAGEN Multiplex PCR Handbook 10/2010). Obtivemos sucesso na amplificação de todas as amostras visando à detecção da mutação $B R A F^{V 600 E}$.

\subsubsection{Detecção da mutação BRAF ${ }^{\mathrm{V} 600 \mathrm{E}}$ em amostras de CPT}

Iniciamos a detecção da mutação $B R A F^{V 600 E}$ por sequenciamento direto, através do método Sanger, conforme descrito em métodos. Um total de 51 amostras foi analisado e detectamos $15(29,4 \%)$ amostras positivas para $B R A F^{V 600 E}$. 
Recentemente foram desenvolvidos métodos com alta sensibilidade e especificidade para a detecção da mutação BRAF $^{V 600 E}$, entre eles a imunohistoquímica e a PCR em tempo real. Utilizamos, portanto, estas duas técnicas para confirmar os resultados obtidos por sequenciamento.

Os ensaios por imuno-histoquímica mostraram-se mais sensíveis: nem sempre amostras positivas para $B R A F^{V 600 E}$ detectado por imuno-histoquímica eram positivas quando sequenciadas. No entanto, o oposto não era observado. As amostras negativas se confirmavam pelas duas técnicas.

Avaliando estes resultados em função da quantidade de tumor presente nas amostras, observamos que amostras positivas para a mutação através do sequenciamento sempre apresentaram considerável porcentagem de tumor, enquanto que amostras negativas para a mutação apresentaram porcentagens de tumor abaixo de 20\%. Esta característica pode ser observada, por exemplo, para os pacientes TIR58, TIR62 e TIR64 (positivos para BRAF e com mais de 50\% de tumor na amostra), e TIR57, TIR71, TIR93 e TIR95 (negativas para BRAF e com menos de $20 \%$ de tumor na amostra) (Tabela 10). Entretanto, encontramos algumas amostras com porcentagem de tumor significativa (> 30\%) e resultados inconsistentes entre as duas técnicas.

Considerando as observações acima, selecionamos esses 5 pacientes (TIR61, TIR74, TIR76, TIR90 e TIR91) negativos para a mutação por sequenciamento, mas positivos por imuno-histoquímica, para que o sequenciamento fosse refeito utilizando-se amostras enriquecidas em células tumorais pela técnica de macro-dissecção. Após macro-dissecadas, dentre os 5 pacientes, duas amostras apresentaram-se positivas para a mutação - TIR74 e TIR90 - confirmando os resultados de imuno-histoquímica para estas amostras.

Utilizamos ainda, como técnica alternativa, a PCR em tempo real. Esta técnica confirmou todos os resultados de imuno-histoquímica. Com esses resultados, as amostras mutadas passaram de $15(29,4 \%)$ para 28 (54,9\%). 
Tabela 10: Caracterização dos pacientes quanto à mutação no gene $B R A F^{V 600 E}$ e resultados da análise morfométrica.

\begin{tabular}{|c|c|c|c|c|c|c|}
\hline \multirow[b]{2}{*}{ Paciente } & \multirow[b]{2}{*}{$\begin{array}{l}\text { Porcentagem } \\
\text { de tumor (\%) }\end{array}$} & \multirow[b]{2}{*}{$\begin{array}{l}\text { Área total } \\
\left(\mathrm{mm}^{2}\right)\end{array}$} & \multicolumn{4}{|c|}{ BRAFV600E } \\
\hline & & & $\begin{array}{l}\text { Método de } \\
\text { Sanger }\end{array}$ & $\begin{array}{c}\text { Imuno- } \\
\text { histoquímica }\end{array}$ & $\begin{array}{l}\text { qRT- } \\
\text { PCR }\end{array}$ & $\begin{array}{c}\text { Porcentagem de } \\
\text { células mutadas (\%) - } \\
\text { qRT-PCR }\end{array}$ \\
\hline TIR1 & 39,76 & 112,64 & Pos & - & - & \\
\hline TIR2 & - & - & Pos & - & - & \\
\hline TIR3 & 41,31 & 64,67 & Pos & - & - & \\
\hline TIR4 & - & - & $\mathrm{Neg}$ & - & - & \\
\hline TIR5 & 37,03 & 205,40 & $\mathrm{Neg}$ & - & $\mathrm{Neg}$ & \\
\hline TIR6 & 31,12 & 210,25 & $\mathrm{Neg}$ & - & Neg & \\
\hline TIR48 & 6,32 & 34,28 & $\mathrm{Neg}$ & Pos & Pos & 17 \\
\hline TIR50 & 94,08 & 213,90 & $\mathrm{Neg}$ & - & $\mathrm{Neg}$ & \\
\hline TIR51 & 1,23 & 181,13 & $\mathrm{Neg}$ & - & $\mathrm{Neg}$ & \\
\hline TIR52 & 80,28 & 100,74 & Neg & - & Neg & \\
\hline TIR53 & 89,20 & 66,01 & $\mathrm{Neg}$ & Pos & Pos & 29,7 \\
\hline TIR54 & 4,43 & 201,88 & Neg & $\mathrm{Neg}$ & - & \\
\hline TIR55 & 0,18 & 281,77 & $\mathrm{Neg}$ & - & $\mathrm{Neg}$ & \\
\hline TIR56 & 13,79 & 178,80 & Pos & Pos & - & \\
\hline TIR57 & 13,02 & 115,99 & $\mathrm{Neg}$ & & $\mathrm{Neg}$ & \\
\hline TIR58 & 83,48 & 214,47 & Pos & Pos & - & \\
\hline TIR59 & 79,76 & 198,56 & $\mathrm{Neg}$ & $\mathrm{Neg}$ & - & \\
\hline TIR60 & 14,82 & 211,71 & $\mathrm{Neg}$ & Neg & - & \\
\hline TIR61 & 75,74 & 205,44 & $\mathrm{Neg}$ & Pos & Pos & 19,1 \\
\hline TIR62 & 55,24 & 376,92 & Pos & Pos & - & \\
\hline TIR63 & 18,30 & 81,22 & $\mathrm{Neg}$ & $\mathrm{Neg}$ & - & \\
\hline TIR64 & 69,08 & 329,44 & Pos & Pos & - & \\
\hline TIR65 & 38,12 & 244,68 & $\mathrm{Neg}$ & $\mathrm{Neg}$ & - & \\
\hline TIR66 & 8,31 & 86,75 & Pos & Pos & - & \\
\hline TIR67 & 35,98 & 72,69 & $\mathrm{Neg}$ & Neg & - & \\
\hline TIR68 & 29,97 & 110,17 & $\mathrm{Neg}$ & Pos & Pos & 5,56 \\
\hline TIR70 & 79,94 & 208,07 & $\mathrm{Neg}$ & $\mathrm{Neg}$ & - & \\
\hline TIR71 & 9,24 & 226,08 & $\mathrm{Neg}$ & Pos & Pos & 4,95 \\
\hline TIR72 & 74,25 & 104,65 & Pos & Pos & - & \\
\hline TIR73 & 10,30 & 69,78 & $\mathrm{Neg}$ & Pos & Pos & 5,11 \\
\hline TIR74 & 65,07 & 76,52 & Pos & Pos & - & \\
\hline TIR75 & 4,00 & 226,17 & $\mathrm{Neg}$ & $\mathrm{Neg}$ & - & \\
\hline TIR76 & 31,96 & 312,93 & $\mathrm{Neg}$ & Pos & $\mathrm{Neg}$ & \\
\hline TIR78 & 30,00 & 149,67 & Pos & & - & \\
\hline TIR79 & 0,73 & 187,72 & $\mathrm{Neg}$ & Neg & $\mathrm{Neg}$ & \\
\hline TIR80 & 8,67 & 173,50 & Pos & Pos & - & \\
\hline TIR81 & 95,00 & 160,90 & Pos & - & - & \\
\hline TIR83 & 29,41 & 100,75 & $\mathrm{Neg}$ & - & $\mathrm{Neg}$ & \\
\hline TIR84 & 11,65 & 228,99 & $\mathrm{Neg}$ & $\mathrm{Neg}$ & - & \\
\hline TIR86 & 0,31 & 91,50 & $\mathrm{Neg}$ & Neg & - & \\
\hline TIR87 & 0,71 & 64,73 & $\mathrm{Neg}$ & Neg & - & \\
\hline TIR89 & 10,26 & 435,20 & $\mathrm{Neg}$ & Pos & $\mathrm{Neg}$ & \\
\hline TIR90 & 29,60 & 194,10 & Pos & Pos & - & \\
\hline TIR91 & 65,62 & 170,18 & $\mathrm{Neg}$ & Pos & Pos & 22,7 \\
\hline TIR92 & 16,27 & 144,38 & Pos & Pos & Pos & 12,6 \\
\hline TIR93 & 1,29 & 205,45 & $\mathrm{Neg}$ & Pos & Pos & 1,6 \\
\hline TIR94 & 30,00 & 165,57 & $\mathrm{Neg}$ & $\mathrm{Neg}$ & - & \\
\hline TIR95 & 3,75 & 238,14 & Neg & Pos & Pos & 2,49 \\
\hline TIR97 & 32,34 & 161,76 & Pos & - & - & \\
\hline TIR98 & 23,06 & 223,66 & Pos & - & Pos & 36 \\
\hline TIR99 & 17,26 & 97,03 & $\mathrm{Neg}$ & - & $\mathrm{Neg}$ & \\
\hline
\end{tabular}




\subsubsection{Detecção da rearranjo RET/PTC em amostras de CPT}

Avaliamos a presença dos rearranjos RET/PTC em parte das amostras negativas para a mutação $B R A F^{V 600 E}(n=14)$.

Para avaliar a mutação por PCR em tempo real foi necessário extrair RNA das amostras emblocadas em parafina. Como controle de qualidade das amostras quanto a inibidores de reação de PCR utilizamos primers para o gene HPRT (com fragmentos gerados de $74 \mathrm{pb}$ ). Das quatorze amostras, 10 amplificaram com sucesso. No entanto, quando o gene de referência GAPDH, com amplicons de 143 $\mathrm{pb}$, foi utilizado, nenhuma das amostras amplificou adequadamente. Consequentemente, não foi possível avaliar se as amostras negativas para a mutação em BRAF possuíam ou não a translocação RET/PTC.

\subsubsection{Detecção de mutação em KRAS em amostras de CPT}

Dezoito amostras, todas negativas para a mutação $B R A F^{V 600 E}$, foram submetidas a PCR convencional para amplificação das regiões dos códons 12/13 e 61. No entanto, apenas oito amostras amplificaram com sucesso e apenas para o códon 61 (TIR54, TIR59, TIR60, TIR63, TIR65, TIR84, TIR87, TIR94). Os resultados de sequenciamento para estas oito mostraram não haver mutação KRAS códon 61.

O ensaio para o códon 12/13 não foi bem sucedido. As reações foram refeitas diversas vezes, aumentando-se a quantidade de material de partida, trocando-se os reagentes e o termociclador. Todas as tentativas foram em vão.

\subsection{Expressão de miRNAs em função das mutações frequentes}

Para avaliar se a relação entre miRNAs miR-146b, miR-221 e miR-222 e a presença de mutações pode ser confirmada, selecionamos, além das amostras utilizadas nos ensaios anteriores (item 4.2, $n=19$ ), 20 amostras de carcinoma papilífero de tireoide, totalizando 39 amostras avaliadas quanto à mutação em BRAF. Optamos por avaliar essa relação por essa mutação ser a mais comumente observada em carcinoma papilífero e por termos obtido resultados satisfatórios na sua detecção. Das 39 amostras selecionadas 24 eram positivas para a mutação BRAF e 15 amostras eram negativas para esta mutação. Os valores de expressão foram normalizados com RNU48 e comparados a uma amostra livre de tumor 
(bócio). Todas as amostras foram macro-dissecadas para o ensaio de expressão gênica.

Resultados anteriores apresentados neste trabalho mostraram, na maior parte dos casos, maior expressão dos miR-146b, miR-221 e miR-222 no CPT quando comparado ao bócio (Figura 16A, B,C). As mesmas observações foram feitas quando acrescentamos mais 20 amostras ao estudo. A figura 16 resume os valores de expressão encontrados para todos os pacientes avaliados. 
A

miR146b

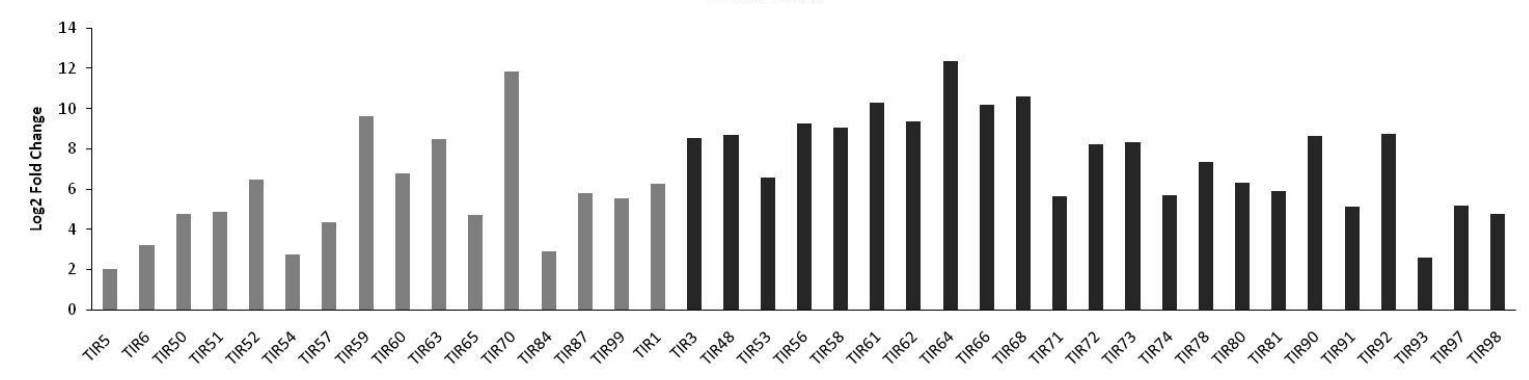

B

miR221

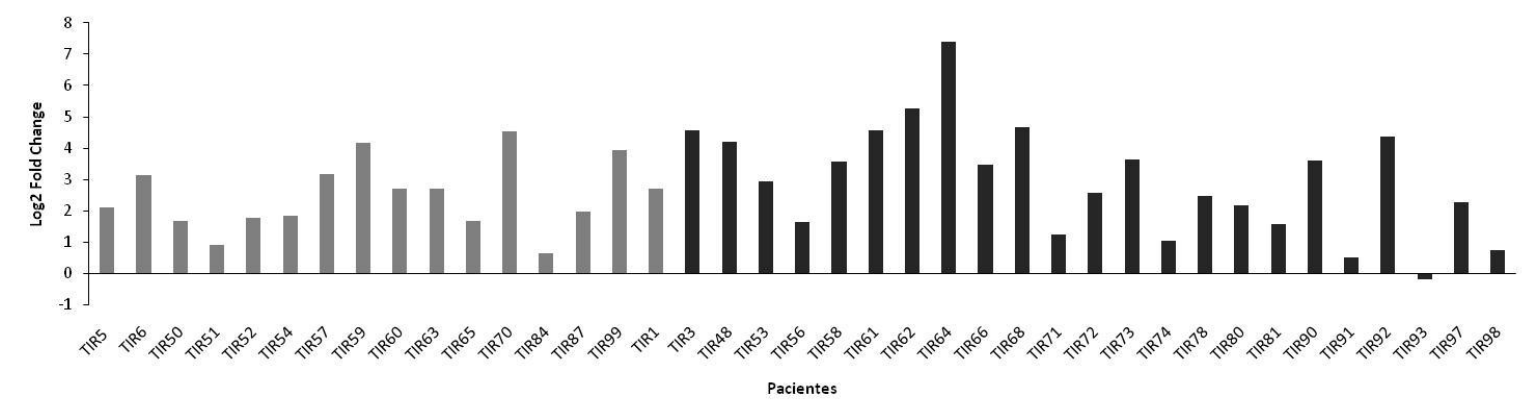


C

$\operatorname{miR222}$

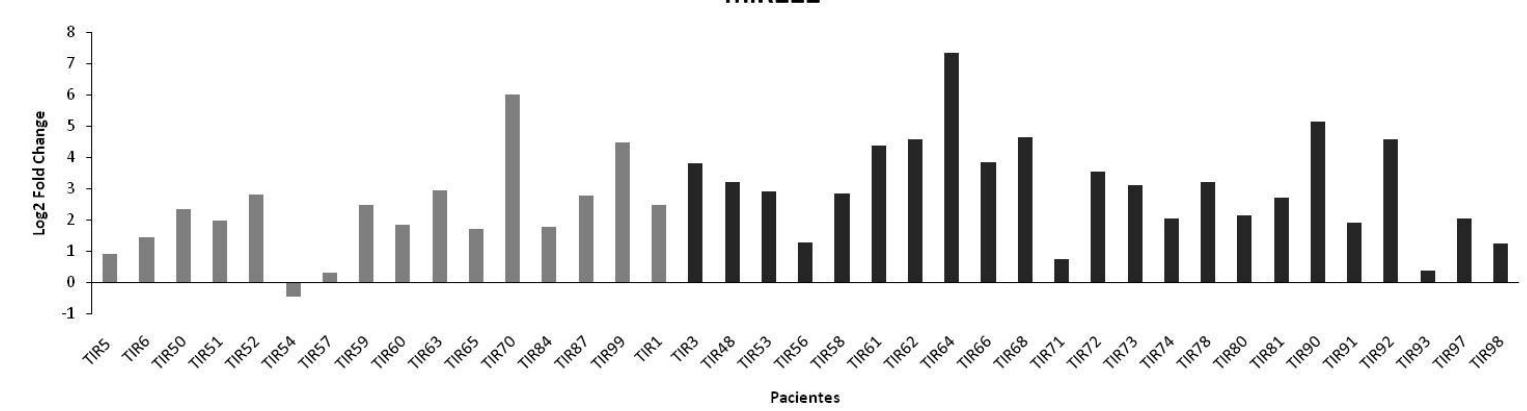

Figura 16: Histograma para a expressão relativa do miR-146b (A), miR-221 (B) e miR-222 (C) em 39 amostras tumorais (CPT) comparadas com o valor médio de expressão de uma amostra de um paciente que passou por cirurgia para retirada de bócio. Eixo $x$ indica cada um dos pacientes analisados. Eixo y apresenta a expressão relativa expressa em $\log _{2}$ do fold change. Valores acima de zero indicam maior expressão na amostra tumoral. Em cinza claro estão as amostras negativas para a mutação BRAF ${ }^{\mathrm{V} 600 \mathrm{E}}$. Em cinza escuro estão as amostras positivas para esta mutação. 
Quando avaliamos a relação entre a expressão de miRNAs e a presença da mutação BRAF ${ }^{\mathrm{V} 600 \mathrm{E}}$, observamos diferença estatisticamente significativa apenas para o miR-146b ( $p=0,013)$, que apresentou-se mais expressos nas amostras contendo a mutação quando comparados as amostras sem mutação. Os miRNAs miR-221 e miR-222 mostraram uma tendência de maior expressão nas amostras positivas para BRAF, que não foi comprovada estatisticamente $(p=0,37$ e $p=0,055$, respectivamente) (Figura 17). 
A

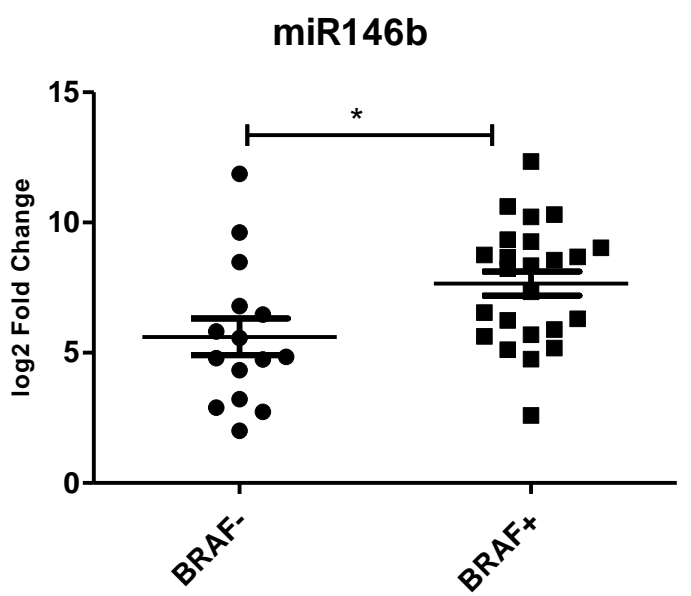

B

$\operatorname{miR221}$

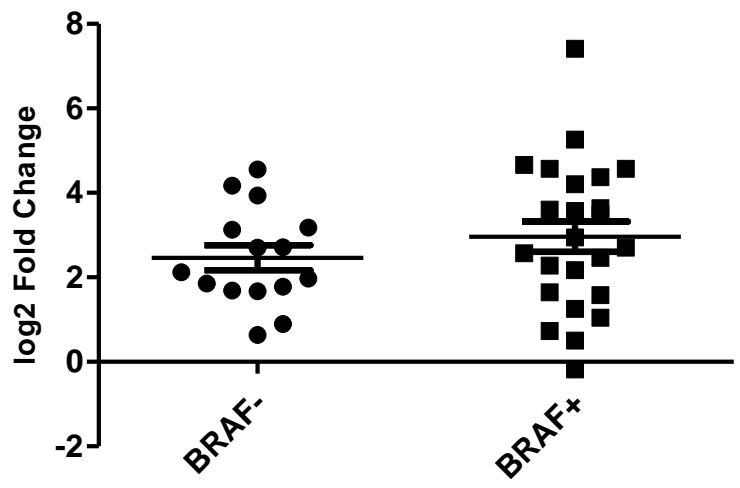

C

miR222

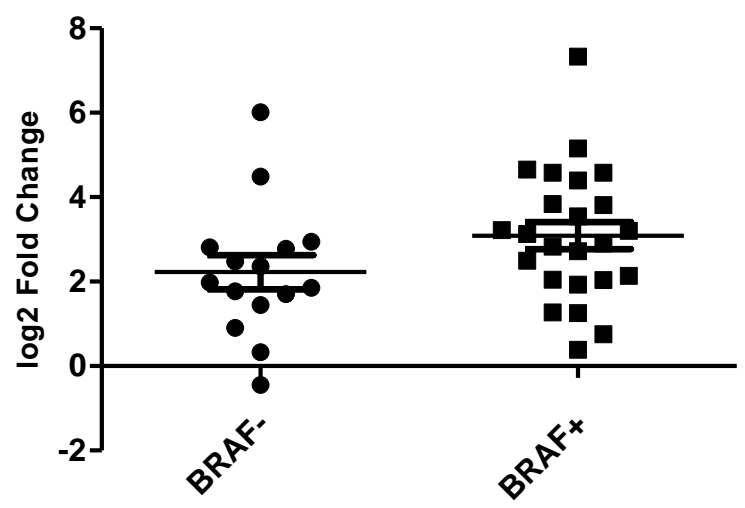

Figura 17: Expressão relativa de miRNAs, representada em $\log _{2}$ do fold change, em amostras positivas e negativas para a mutação BRAF comparadas a uma amostra de bócio. (A) $\log _{2}$ do fold change para o miR-146b mostra diferença estatisticamente significativa de expressão entre amostras positivas e negativas para BRAF $(p=0,013)$, (B) $\log _{2}$ do fold change para o miR-221 não mostra diferença estatisticamente significativa de expressão entre amostras positivas e negativas para BRAF $(p=0,37)$ e $(C) \log _{2}$ do fold change para 0 miR-222 não mostra diferença estatisticamente significativa de expressão entre amostras positivas e negativas para BRAF $(p=0,055)$. 


\subsection{MiRNAs possivelmente associados à mutação BRAF ${ }^{\mathrm{V} 600 \mathrm{E}}$ encontrados} através da análise dos resultados de microarranjos de DNA e relação com vias de sinalização relacionadas ao CPT

Questionamos se outros miRNAs, além dos analisados acima, poderiam estar relacionados com a presença da mutação BRAF. Para avaliar esta hipótese, realizamos um ensaio de expressão global de miRNAs em amostras positivas e negativas para a mutação BRAF.

Foram selecionadas 10 amostras, 6 positivas (TIR66, TIR71, TIR73, TIR80, TIR90A, TIR92) e 4 negativas (TIR67, TIR70, TIR84, TIR90B) para a mutação BRAF, com porcentagens de tumor acima de 30\%.

Os resultados de expressão global mostraram 891 miRNAs com intensidade de sinal acima do ruído de fundo. A figura abaixo (Figura 18) mostra a quantidade de miRNAs detectados para cada uma das amostras individualmente.

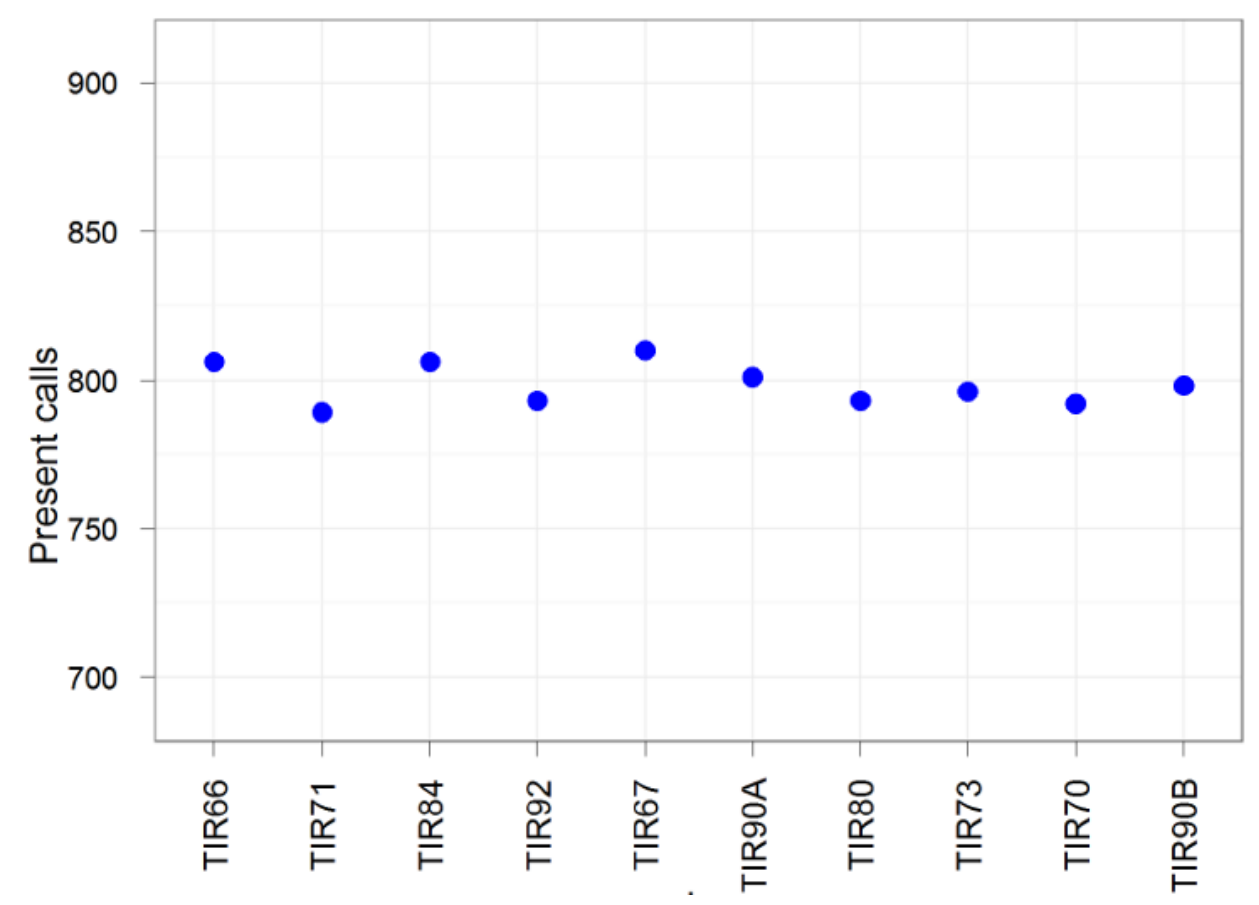

Figura 18: Histograma mostrando o número de miRNAs detectados acima do valor de ruído de fundo para cada uma das amostras individualmente, de um total de 2084 miRNAs avaliados.

Ao comparamos amostras positivas e negativas para BRAF ${ }^{\mathrm{V} 600 \mathrm{E}}$ encontramos alguns miRNAs pelo menos duas vezes mais expressos nas amostras positivas para 
a mutação (Tabela 11). Dentre os mais expressos estavam os miRNAs miR-146b, miR-221 e miR-222.

Tabela 11: Lista dos miRNAs encontrados mais expressos em amostras positivas para a mutação BRAF $^{\mathrm{V} 600 \mathrm{E}}$ comparadas a amostras negativas para a mutação, após análise de expressão global de miRNAs por microarranjos de DNA.

\begin{tabular}{lc}
\hline \multicolumn{1}{c}{ miRNA } & $\log _{2}$ Fold Change (BRAF + vs. BRAF -) \\
\hline hsa-miR-92a-3p & 2,005 \\
hsa-miR-146b-3p & 2,017 \\
hsa-miR-142-5p & 2,072 \\
hsa-miR-135a-5p & 2,073 \\
hsa-miR-20a-5p & 2,161 \\
hsa-miR-4284 & 2,176 \\
hsa-miRPlus-A1086 & 2,229 \\
hsa-miR-31-5p & 2,263 \\
hsa-miR-4288 & 2,674 \\
hsa-miR-4668-5p & 2,816 \\
hsa-miR-200b-3p & 3,041 \\
hsa-miR-146a-5p & 3,220 \\
hsa-miR-200a-3p & 3,250 \\
hsa-miR-222-3p & 3,448 \\
hsa-miR-221-3p & 3,582 \\
hsa-miR-142-3p & 4,081 \\
hsa-miR-146b-5p & 9,885 \\
\hline \hline
\end{tabular}

Além dos miRNAs listados acima, encontramos os miRNAs miR-146a, miR16, miR-19a e miR-21 mais expressos no grupo de amostras positivas para a mutação BRAF ${ }^{\mathrm{V} 600 \mathrm{E}}$ quando comparado ao grupo de amostras negativas para essa mutação.

Para avaliar se a diferença de expressão desses miRNAs era consistente entre amostras positivas e negativas para a mutação BRAF, validados os resultados por PCR em tempo real em um grupo adicional de amostras. As mesmas 39 amostras avaliadas para os miRNAs miR-146b, miR-221 e miR-222 foram utilizadas no ensaio.

Os resultados mostraram haver uma grande variação na expressão de cada um dos pacientes avaliados individualmente, apresentando alguns, maior expressão, enquanto outros apresentaram menor expressão quando comparado à amostra livre de tumor (bócio) (Figura 19). 
A

miR146a

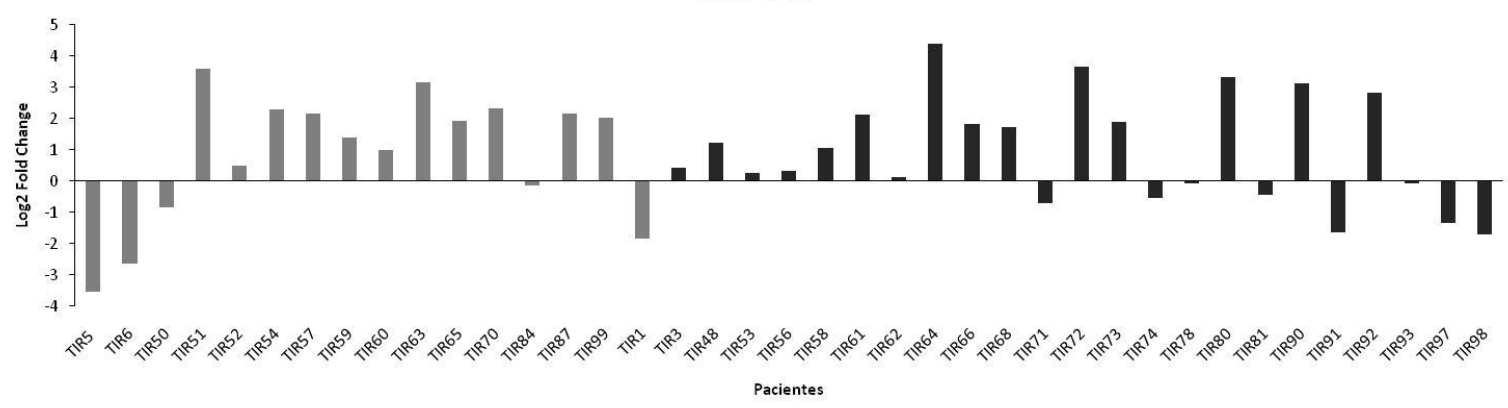

B

miR16

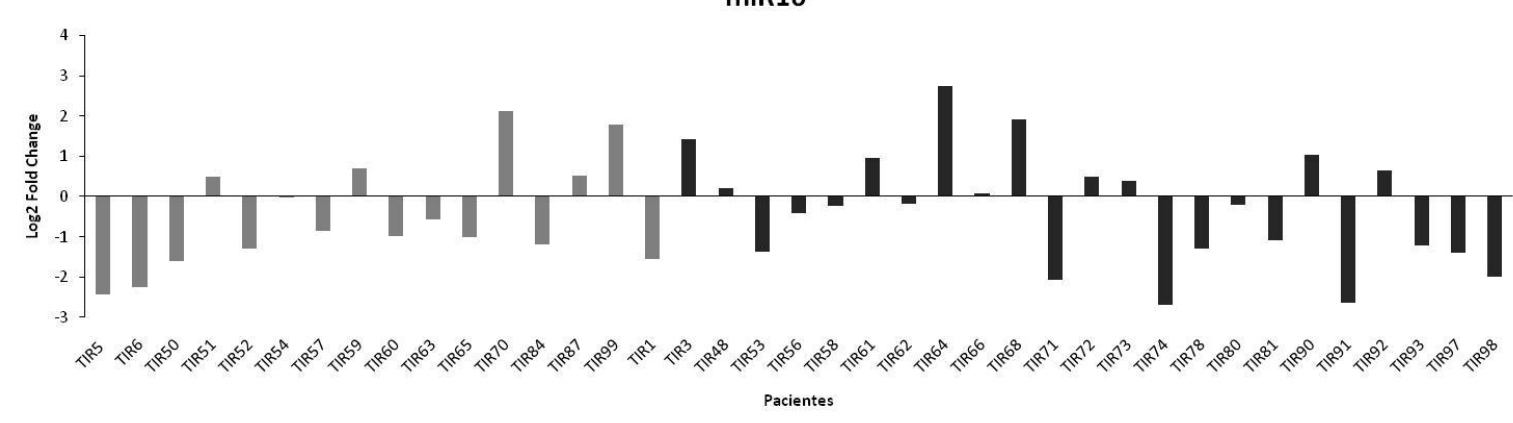

C

$\operatorname{miR21}$

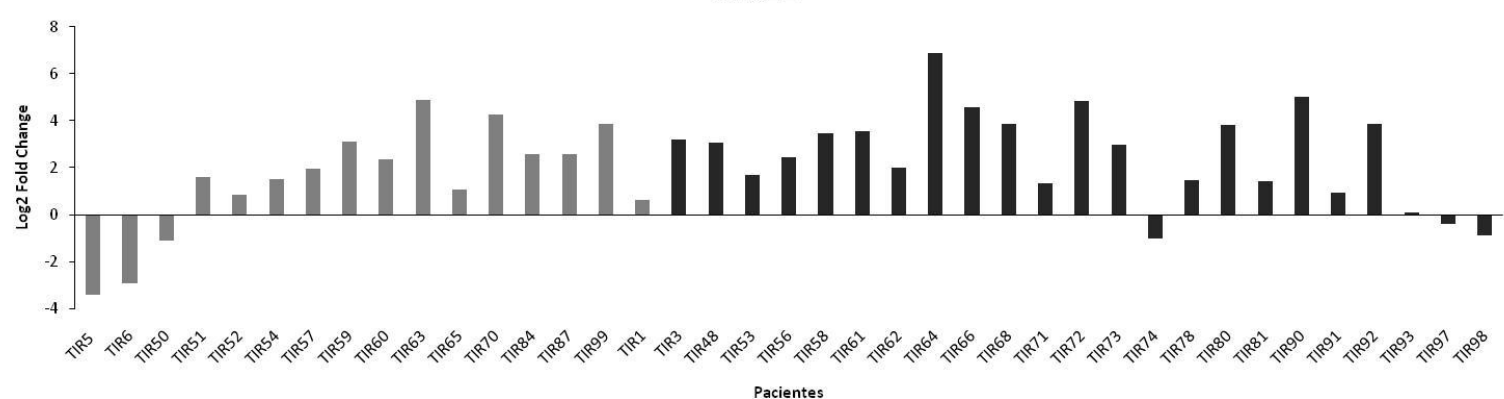

D

miR19a

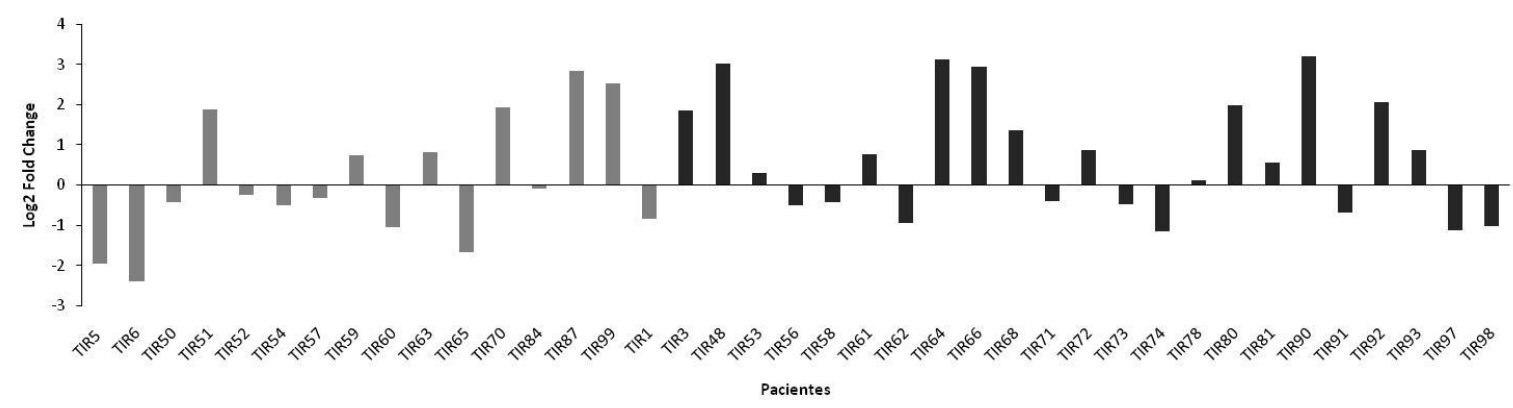

Figura 19: Histograma para a expressão relativa do miR-146a (A), miR-16 (B), miR-21 (C) e miR-19a (D) em 39 amostras tumorais (CPT) comparadas com o valor médio de expressão de uma amostra de um paciente que passou por cirurgia para retirada de bócio. Eixo $x$ indica cada um dos pacientes analisados. Eixo $y$ apresenta a expressão relativa expressa em $\log _{2}$ do fold change. Valores acima de zero indicam maior expressão na amostra tumoral. Em cinza claro estão as amostras negativas para a mutação BRAF ${ }^{\mathrm{V} 600 \mathrm{E}}$. Em cinza escuro estão as amostras positivas para esta mutação. 
Ao compararmos os resultados entre o grupo de amostras positivo para BRAF e negativo para a mutação, não observamos diferença significativa para nenhum dos miRNAs avaliados (Figura 20).

miR146a

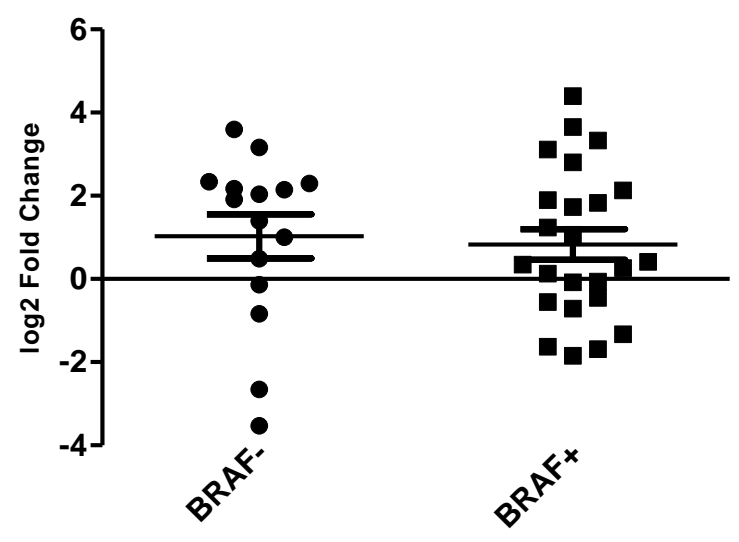

A

miR19a

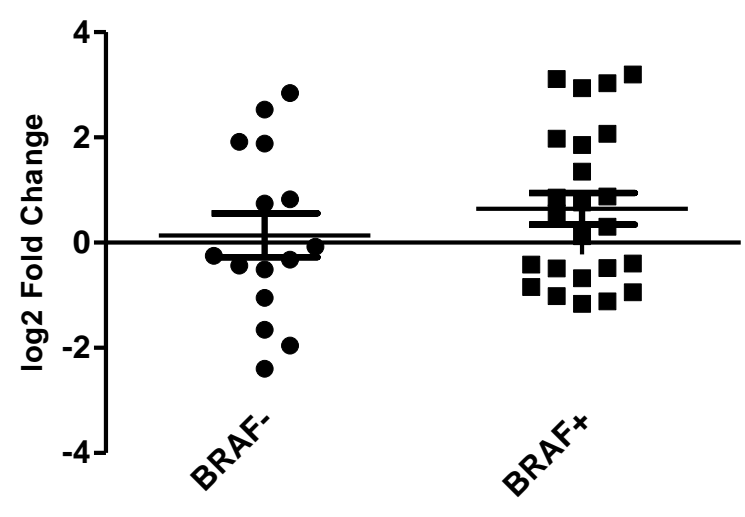

C
$\operatorname{miR} 16$

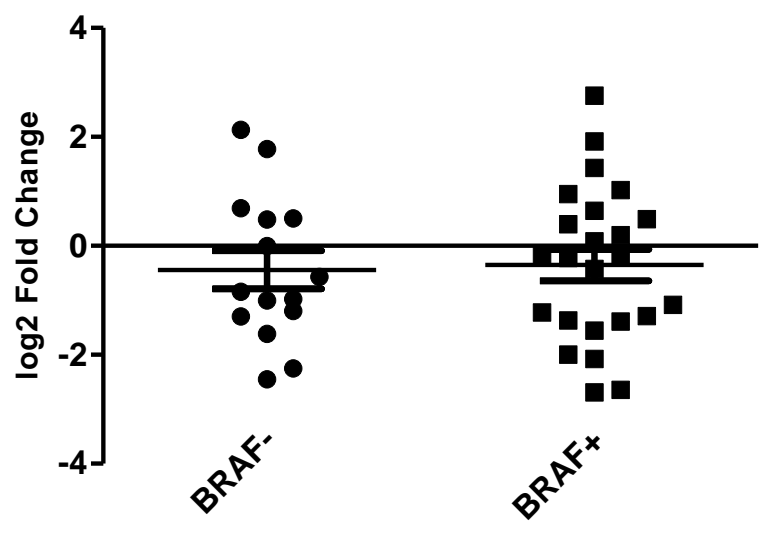

B

$\operatorname{miR21}$

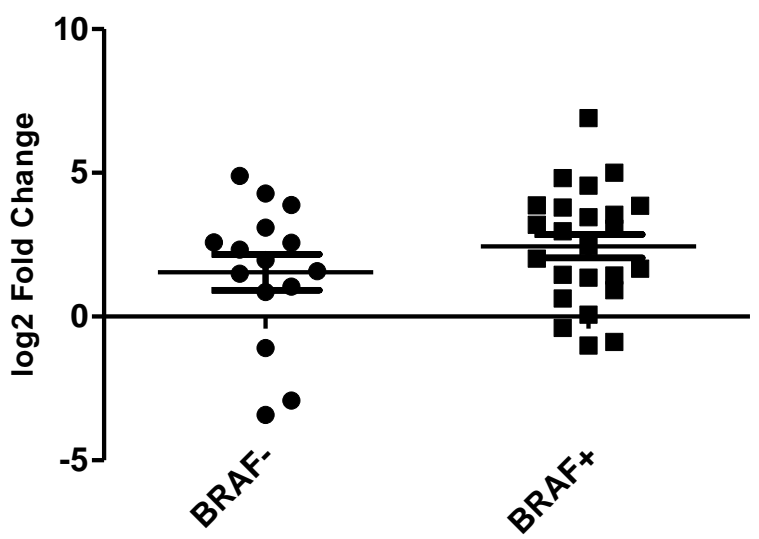

D

Figura 20: Expressão relativa de miRNAs, representada em $\log _{2}$ do fold change, em amostras positivas e negativas para a mutação BRAF comparadas a uma amostra de bócio. Nenhum dos miRNAs apresentou diferença estatisticamente significativa entre amostras positivas e negativas para BRAF (A) miR-146a $(p=0,44)$, (B) miR-16 $(p=0,94)$, (C) miR19a $(p=0,38)$, (D) miR-21 $(p=0,39)$.

Apesar de resultados não estatisticamente significativos, observamos diferenças na expressão destes miRNAs entre pacientes, miRNAs estes associados com vias de sinalização importantes para o CPT. 


\section{DISCUSSÃO}

Tecidos emblocados em parafina representam a maior parte das amostras biológicas armazenadas ao longo dos anos pelos departamentos de histopatologia. Essas coleções se tornaram de grande valor para a comunidade científica, pois permitem estudos retrospectivos. Sabe-se que os ácidos nucleicos vão sofrendo degradação com o passar do tempo, comprometendo tanto a qualidade e integridade de moléculas de DNA quanto de RNA. Entretanto evidências experimentais mostram que os miRNAs permanecem bem conservados no material parafinado (Weber et al., 2006), sendo facilmente extraídos desse tipo de amostra devido ao seu pequeno tamanho (Abrahamsen et al., 2003; Godfrey et al., 2000; Lewis et al., 2001; Masuda et al., 1999; Zhang et al., 2008). Diversos grupos mostraram também ser possível obter DNA genômico de material parafinado (Bonin et al., 2003; Bonin et al., 2010; Largey et al., 1993; Lewis et al., 2001; Tang et al., 2009).

Usando amostras frescas livre de tumor e tumoral, e amostras emblocadas em parafina, mostramos expressão comparável para miRNAs extraídos de amostras parafinadas e de amostras congeladas pareadas, corroborando com Zhang e colaboradores (2008). Não observamos correlação entre tempo de fixação do material e idade do bloco (até aproximadamente 10 anos), e variações na expressão gênica de miRNA, corroborando com dados da literatura (Lawrie et al., 2007; Leite et al., 2011; Siebolts et al., 2009; Xi et al., 2007). Desta forma nossos resultados indicaram preservação uniforme dos miRNAs no material de tireoide emblocado em parafina, tornando viável a sua utilização para os demais experimentos. A preservação uniforme de moléculas de pequeno tamanho também foi observada em material corado com H\&E. Estudos mostram que a etapa de desidratação durante o processo de coloração é capaz de estabilizar o RNA e desativar as RNases (Clément-Zina et al., 2008).

DNA também foi extraído com sucesso de material parafinado permitindo a identificação de mutações por sequenciamento por método de Sanger e PCR em tempo real.

Existem diversas mutações descritas em CPT, sendo as mais comumente encontradas em BRAF (BRAF ${ }^{\mathrm{V} 600 \mathrm{E}}$ ), em KRAS (códons 12 e 13 e no códon 61), e rearranjos em RET/PTC. Estas mutações são mutuamente exclusivas, ocorrendo 
raramente em conjunto (Frattini et al., 2004; Kimura et al., 2003; Soares et al., 2003). Utilizamos as técnicas de imunohistoquímica e PCR em tempo real para confirmar os resultados de sequenciamento por método Sanger para a detecção da mutação BRAF $^{\mathrm{V} 600 \mathrm{E}}$. Nossos resultados confirmaram a variabilidade no número de casos de CPT positivos para a mutação $B R A F^{V 600 E}$ encontrada na literatura, evidenciando que o tipo de material utilizado e o método de detecção podem influenciar nos resultados (Kim et al., 2008; Lee et al., 2010; Ricarte-Filho et al., 2009; Riesco-Eizaguirre, Santisteban, 2007; Xing, 2005). Encontramos $54,9 \%$ dos casos positivos para esta mutação. Além disso, foi comprovada a utilidade das técnicas de imuno-histoquímica e PCR em tempo real como ferramentas adicionais na avaliação da mutação BRAF $^{\mathrm{V} 600 \mathrm{E}}$, ressaltando o cuidado na seleção e processamento das amostras ao se utilizar o sequenciamento tradicional para a detecção da mutação.

As mutações em KRAS nos códons 12 e 13 e no códon 61 foram avaliadas por sequenciamento tradicional em amostras negativas para a mutação BRAF ${ }^{\mathrm{V} 600 \mathrm{E}}$. As mutações nos códons 12 e 13 e códon 61 foram avaliadas por serem as de maior prevalência no câncer de tireoide (Park et al., 2013; Rivera et al., 2010; Russo et al., 2005; Suda et al., 2010), mesmo assim, sua frequência é baixa em CPT (Nikiforov et al., 2011; Petersen et al., 2012). Nossos resultados mostraram ausência de mutação no códon 61 para todas as amostras avaliadas, confirmando a baixa frequência observada desta mutação em CPT. O ensaio para o códon 12/13 não foi bem sucedido, mesmo após diversas tentativas. Questionamos se o problema estaria relacionado ao material utilizado ser emblocado em parafina. Apesar de as mesmas amostras terem sido amplificadas com sucesso na avaliação da mutação de interesse em $B R A F^{\mathrm{V} 600 \mathrm{E}}$, o tipo de ligação entre os primers para detecção das mutações em KRAS pode exigir qualidade diferente. Levantamos também a hipótese de que o problema estaria no desenho dos primers para os códons 12 e 13 . Entretanto, estes mesmos primers são utilizados por nossos colaboradores para a avaliação destas mutações em melanoma (resultados não apresentados).

Os rearranjos em RET/PTC foram avaliados por PCR em tempo real em amostras também negativas para a mutação BRAFV600E. Não observamos amplificação adequada para o gene de referência GAPDH utilizado no experimento. A ausência de amplificação do gene de GAPDH indica que o RNA extraído estava, possivelmente, muito degradado para o ensaio selecionado para a detecção de RET/PTC. Entretanto, devido às características clínicas dos casos - pacientes com 
idade avançada e não expostos à radiação - acreditamos que este tipo de alteração não seria encontrada (Jacob et al., 1999; Nikiforov et al., 1997; Thomas et al., 1999).

O miR-146b está descrito como superexpresso em CPT quando comparado a tecido de tireoide livre de tumor (Chen et al., 2008; Chou et al., 2010; He et al., 2005; Mazeh et al., 2011; Nikiforova et al., 2008; Schwertheim et al., 2009; Sheu et al., 2009; Sheu et al., 2010; Sun et al., 2013). A avaliação da expressão deste miRNA em um grupo de amostras heterogêneo quanto à quantidade de tumor emblocada mostrou não haver variação significativa entre os valores de expressão nas amostras tumorais e das amostras livres de tumor quando agrupadas. Esses resultados sugeriram que a heterogeneidade do material tem um grande impacto nos níveis de expressão gênica, fato evidenciado principalmente após a macrodissecção das amostras.

A avaliação pareada de amostras tumorais e não tumorais (que leva em consideração os problemas devido a variações de expressão individual) mostrou maior expressão do miR-146b em 4 dos 5 pacientes avaliados. A análise morfométrica do paciente com menor expressão do miR-146b mostrou significativa infiltração inflamatória no tecido peritumoral. De fato, a família do miR-146 parece ter importante papel regulatório na inflamação, podendo até mesmo ser regulada por fatores inflamatórios (Okada et al., 2010; Sonkoly et al., 2008). Quando avaliados mais pacientes com as mesmas condições associadas, nossos resultados mostraram novamente variabilidade na expressão entre os pacientes, evidenciando a complexidade molecular presente nos tecidos neoplásicos, e as dificuldades de se trabalhar com amostras biológicas.

Para melhor compreensão do impacto da porcentagem de tumor e da quantidade de tecido livre de tumor na expressão gênica em amostras parafinadas, selecionamos 7 pacientes com blocos contendo diferentes porcentagens de tumor, e condições associadas distintas avaliadas pela técnica de morfometria. Foram avaliados os miRNAs miR-146b, miR-221 e miR-222. Os resultados mostraram variabilidade de expressão entre os pacientes e em função da porcentagem de tumor. Acreditamos que resultados sejam devido a características específicas de cada indivíduo, dificultando a comparação de expressão entre pacientes. Esses resultados também ressaltam a influência da área livre de tumor na expressão gênica e a variabilidade dos níveis de expressão individual entre pacientes. Essas características devem ser levadas em consideração, principalmente quando miRNAs 
são considerados como possíveis biomarcadores de câncer. Os níveis de expressão do tecido livre de tumor variam e podem interferir na interpretação dos resultados.

Os dados sobre a relação entre a presença de mutações e a expressão de miRNAs ainda são bastante controversos. Diversos estudos tentaram relacionar a expressão dos miRNAs miR-146b, miR-221 e miR-222, encontrados altamente expresso em CPT, com a presença de mutações (Chou et al., 2010; Nikiforova et al., 2008; Sun et al., 2013). Alguns grupos observaram níveis de expressão significativamente maiores de miR-146b, miR-221 e miR-222 em amostras contendo a mutação em BRAF quando comparadas a amostras sem a mutação (Chou et al., 2010; Sun et al., 2013). No entanto, para outros grupos, a expressão de miR-146b, miR-221 e miR-222 parece independer da presença dessa mutação (Chen et al., 2008; Sheu et al., 2009). Avaliamos a relação entre esses 3 miRNAs e a presença da mutação BRAF ${ }^{\mathrm{V} 600 E}$ em 39 pacientes. Nossos resultados mostraram maior expressão dos 3 miRNAs nas amostras tumorais comparadas a amostras de bócio, corroborando com dados da literatura (Chen et al., 2008; Chou et al., 2010; He et al., 2005; Pallante et al., 2006). Quando avaliamos a relação entre a expressão de miRNAs e a presença da mutação BRAF $^{\mathrm{V} 600 \mathrm{E}}$, observamos diferença estatisticamente significativa apenas para o miR-146b $(p=0,013)$, que apresentouse mais expressos nas amostras contendo a mutação quando comparados as amostras sem mutação, confirmando os estudos de Chou e colaboradores (2010), Nikiforova e colaboradores (2008) e Sun e colaboradores (2013). Os miRNAs miR221 e miR-222 mostraram uma tendência de maior expressão nas amostras positivas para BRAF, que não foi comprovada estatisticamente $(p=0,37$ e $p=0,055$, respectivamente).

Fizemos um ensaio de expressão global de miRNAs em função da mutação $\mathrm{BRAF}^{\mathrm{V} 600 \mathrm{E}}$ para avaliar outros miRNAs que poderiam estar relacionados à presença das mutações frequentes em CPT. Observamos os miR-146b, miR-221 e miR-222 mais expressos nas amostras positivas para BRAF ${ }^{\mathrm{V} 600 \mathrm{E}}$ quando comparado às amostras negativas para a mutação. Maior expressão também foi observada para os miRNAs miR-146a, miR-21, miR-16, miR-19a, miR-200a/b, miR-92a, miR-142, miR20a, miR-31, e miR-135a. Parte deles já está relacionada às vias de MAPK e PI3K/AKT e câncer de tireoide e/ou outros tipos de carcinomas e vias, como descrito tabela 12. 
Tabela 12: MicroRNAs envolvidos nas vias de MAPK e PI3K/AKT.

\begin{tabular}{|c|c|c|c|c|c|}
\hline microRNA & $\begin{array}{l}\text { Localização } \\
\text { genômica }\end{array}$ & Expressão em câncer & Função & Alvos & Referências \\
\hline $\begin{array}{l}\text { Let-7 } \\
\text { Let-7a-2 }\end{array}$ & $11 q 24$ & $\begin{array}{l}\text { Pouco expresso em câncer de } \\
\text { pulmão, de mama, cólon, ovário, } \\
\text { estômago e tireoide. }\end{array}$ & $\begin{array}{l}\text { Supressor } \\
\text { de tumor }\end{array}$ & $\begin{array}{l}\text { KRAS, HMGA2, MYC, DICER, BCL- } \\
\text { XL, IMP-1, CDC34, IL6 }\end{array}$ & $\begin{array}{l}\text { Johnson et al., 2005; } \\
\text { Ricarte-Filho et al., 2009. }\end{array}$ \\
\hline $\begin{array}{l}\mathrm{miR}- \\
125 \mathrm{a} / \mathrm{b}\end{array}$ & $19 / 21$ & & $\begin{array}{l}\text { Supressor } \\
\text { de tumor }\end{array}$ & HER2, HER3 & $\begin{array}{l}\text { Mattie et al., 2006; Nakanishi } \\
\text { et al., 2013; Scott et al., } \\
2007 .\end{array}$ \\
\hline $\operatorname{miR}-146 a$ & 5 & $\begin{array}{l}\text { Superexpresso em câncer de } \\
\text { tireoide }\end{array}$ & Oncogene & TRAF6, IRAK1, CPT1, KIT & $\begin{array}{l}\text { He et al., 2005; Jazdzewski } \\
\text { et al., } 2008 .\end{array}$ \\
\hline $\operatorname{miR}-146 b$ & 10 & $\begin{array}{l}\text { Superexpresso em câncer de } \\
\text { tireoide. }\end{array}$ & Oncogene & KIT & He et al., 2005. \\
\hline $\begin{array}{l}\operatorname{miR}-15 /- \\
16\end{array}$ & $13 q 31$ & $\begin{array}{l}\text { Pouco expresso em leukemia } \\
\text { linfocítica crônica e câncer de } \\
\text { próstata. }\end{array}$ & $\begin{array}{l}\text { Supressor } \\
\text { de tumor }\end{array}$ & $\begin{array}{l}\text { BCL2, COX2, CHECK1, CCNE1, } \\
\text { CCND1, CCND2, BMI-1, FGF2, } \\
\text { FGFR1, VEGF, VEGFR2, CDC25a }\end{array}$ & $\begin{array}{l}\text { Calin et al., 2002; Chen et } \\
\text { al., 2008; Cimmino et al., } \\
\text { 2005; Klein et al., } 2010 .\end{array}$ \\
\hline miR-19a & 13 & & & Rb, PTEN & Takakura et al., 2008. \\
\hline $\begin{array}{l}\text { Família } \\
\text { miR-200 }\end{array}$ & $\begin{array}{l}1 \mathrm{p} 36 \\
12 \mathrm{p} 13\end{array}$ & $\begin{array}{l}\text { Pouco expresso em câncer de } \\
\text { mama agressivo. }\end{array}$ & $\begin{array}{l}\text { Supressor } \\
\text { de tumor }\end{array}$ & $\begin{array}{l}\text { ZEB1, ZEB2, BMI-1, SUZ-12, FN1, } \\
\text { LEPR, CTNNB1, JAG1, MALM2, } \\
\text { MALM3, p38alpha }\end{array}$ & Di Leva, Croce, 2013. \\
\hline
\end{tabular}




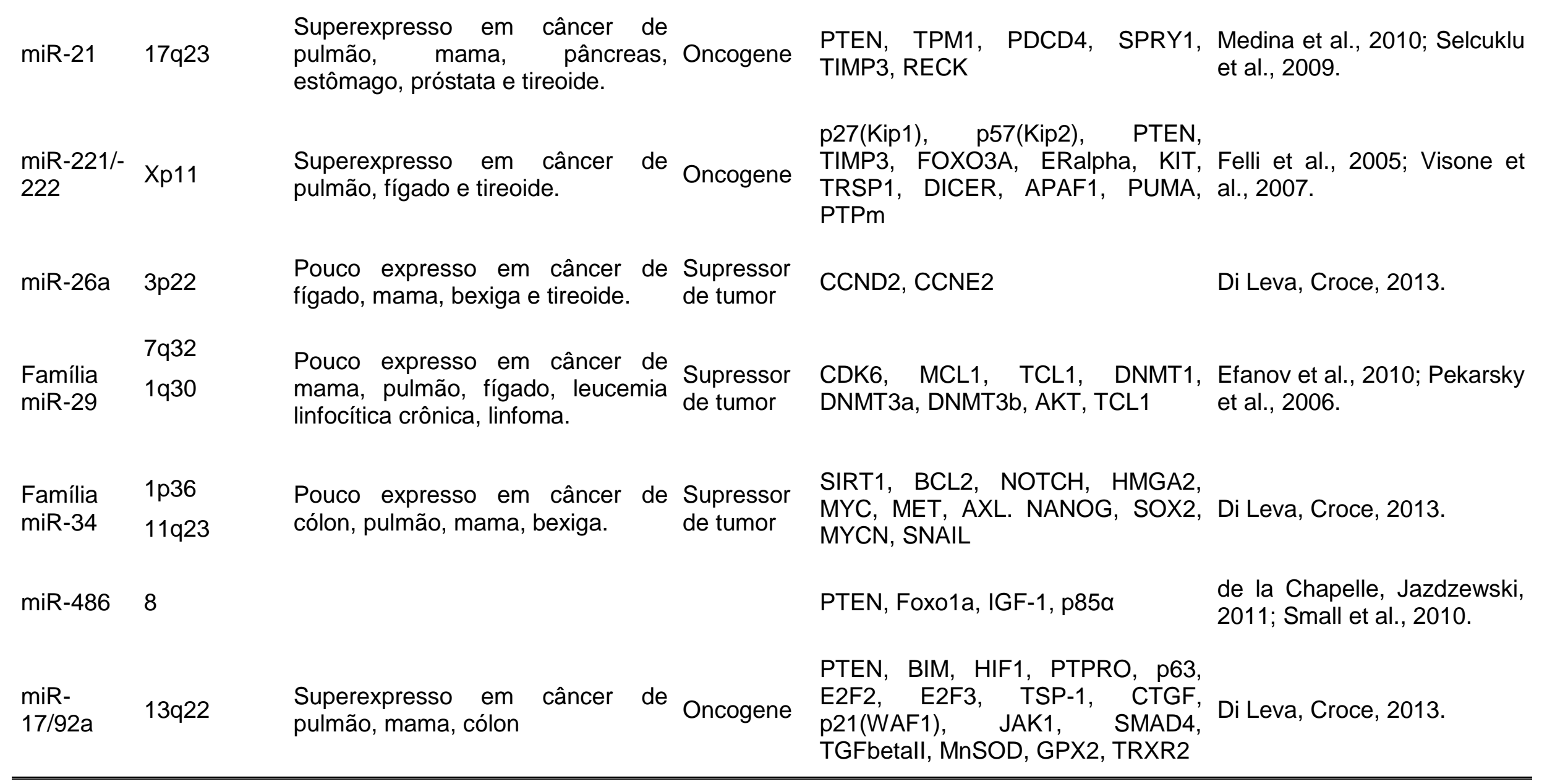


Avaliamos se a expressão dos miR-146a, miR-21, miR-16, miR-19a era de fato consistentemente diferente entre amostras positivas e negativas para a mutação BRAF $^{\mathrm{V} 600 \mathrm{E}}$, utilizando a técnica de $\mathrm{PCR}$ em tempo real em um grupo adicional de amostras. Ao compararmos os resultados entre o grupo de amostras positivo para $\mathrm{BRAF}^{\mathrm{V} 600 \mathrm{E}}$ e negativo para a mutação, não observamos diferença significativa para nenhum dos miRNAs avaliados ( $p>0.05$ ). Não existem dados previamente publicados na literatura sobre esta possível associação. No entanto, estes miRNAs podem participar na regulação fina da expressão de vias relacionadas ao CPT e contribuir para fenótipos mais ou menos agressivos da doença. Neste trabalho encontramos alguns miRNAs mais expressos em amostras positivas para a mutação BRAF $^{\mathrm{V} 600 \mathrm{E}}$, sugerindo que uma combinação complexa de atuação de miRNAs deve estar envolvida nas alterações das vias de MAPK e PI3K/AKT contribuindo para o fenótipo de CPT. A Figura 21 ilustra esta possível relação e a seguir apresentamos estudos que avaliaram o papel de miRNAs que apresentaram expressão diferencial entre amostras que apresentavam e não apresentavam a mutação BRAF ${ }^{\mathrm{V} 600 \mathrm{E}}$ no câncer.

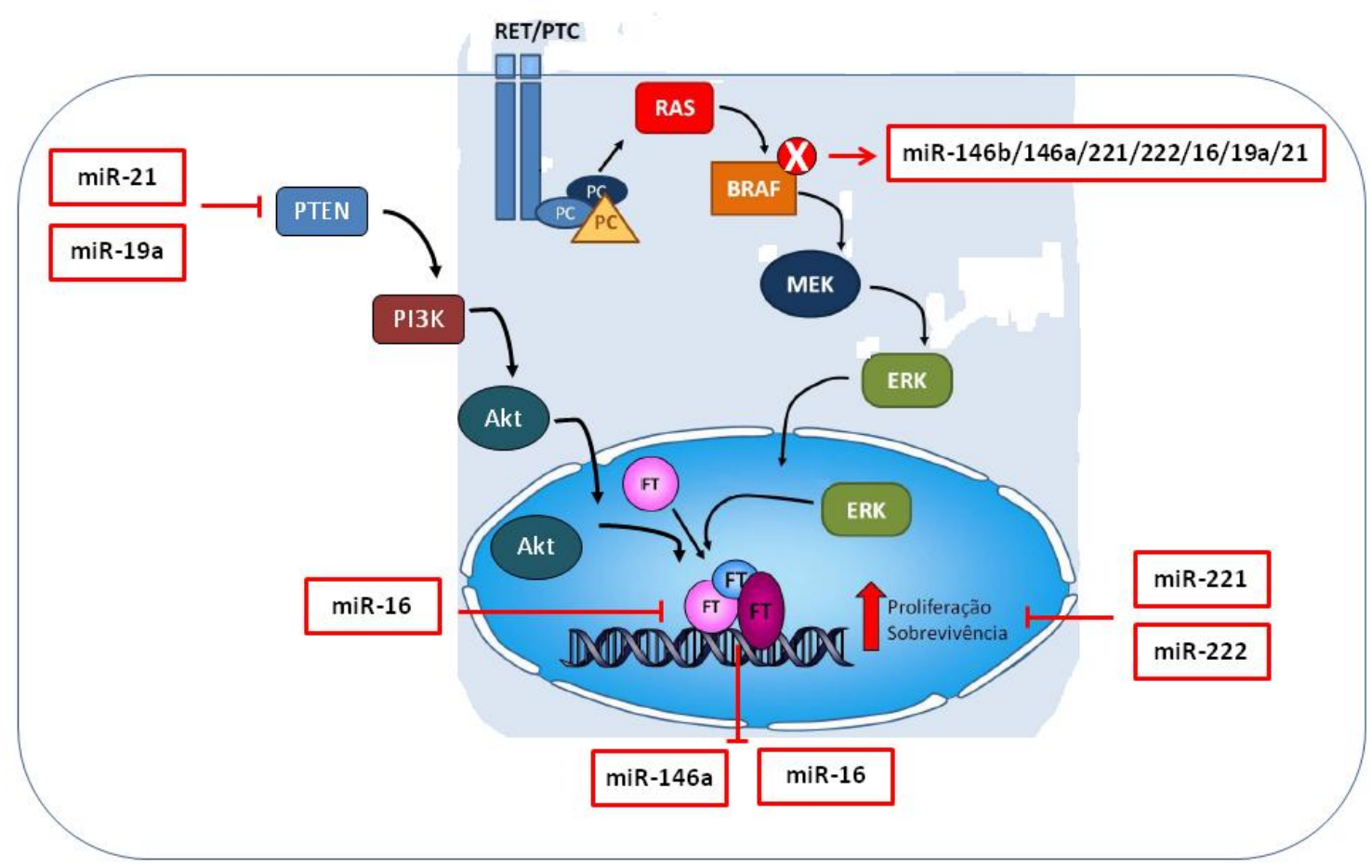

Figura 21: Esquema de sinalização das vias de MAPK e PI3K/AKT, evidenciando a alteração BRAFV600E (X), e sua relação com miRNAs. Adaptado de de la Chapelle, Jazdzewski, 2011. 
A via de MAPK apresenta papel fundamental na proliferação e sobrevivência celular, contribuindo para o processo tumorigênico (Xing et al., 2013). Sua importância está bem caracterizada em CPT (Kondo et al., 2006; Xing, 2008), sendo ativada por mutações que incluem BRAF, RAS e RET/PTC (Murugan, Xing, 2011) O processo tumorigênico mediado pela via de MAPK pode envolver a superexpressão de várias proteínas, incluindo quimiocinas (Melillo et al., 2005; Oler et al., 2008), VEGFA (Jo et al., 2006), MET (Giordano et al., 2005; Kumagai et al., 2006), NF- kB (Palona et al., 2006), metaloproteinases (Melillo et al., 2005; Mesa et al., 2006; Palona et al., 2006) proibitina (Franzoni et al., 2009), vimentina (Watanabe et al., 2009), HIF1a (Zerilli et al., 2010), PROK1 (também conhecida como EG-VEGF) (Pasquali et al., 2011), uPA e seu receptor uPAR (Nowicki et al., 2010; Nowicki et al., 2011), TGFß1 (Knauf et al., 2011; Nucera et al. 2010; Riesco-Eizaguirre et al., 2009) e TSP1 (Nucera et al., 2010). Essas proteínas são conhecidas por controlarem mecanismos diversos que levam a proliferação celular, crescimento, migração, sobrevivência, angiogênesis, invasão e metástase. Parte delas compõe a matriz extracelular, e parece exercer papel importante no desenvolvimento do câncer de tireoide mediado por oncoproteínas como BRAF ${ }^{\mathrm{V} 600 \mathrm{E}}$ (Nucera et al., 2011).

A via de PI3K-AKT também apresenta papel fundamental na tumorigênese de tireoide (Saji, Ringel, 2010; Xing, 2010) e parece ocorrer espontaneamente (Miyakawa et al., 2003; Ringel et al., 2001; Vasko et al., 2004). A ativação dessas vias pode levar a alterações secundárias nas vias de WNT- $\beta$-catenin (Abbosh, Nephew, 2005) (envolve genes promotores de tumor), FOXO3 (envolve genes próapoptóticos) (Guigon et al., 2009) e NF-KB (envolve genes promotores de tumor e genes anti-apoptóticos) (Guigon et al., 2009).

MiR-146b, miR-221 e miR-222 foram encontrados superexpressos em CPT. Sua contribuição para o fenótipo tumoral pode estar relacionada a possíveis alvos das via de MAPK e PI3K/AKT, como por exemplo, p27/kip1 e p57/kip2, fatores de regulação do ciclo celular (Liang et al., 2002; Viglietto et al., 2002; Visone et al., 2007; Shin et al., 2002). Esses miRNAs são também capazes de levar à diminuição dramática KIT, tanto proteína quanto transcrito (He et al., 2005). KIT é um receptor tirosina quinase capaz de ativar as duas vias (MAPK e PI3K) (Todd et al., 2012), e sua proteína está ausente em CPTs, sugerindo sua associação com o fenótipo maligno das células neoplásicas de tireoide (Natali et al., 1995). MiR-221 e miR-222 
podem também atuar diretamente sobre PTEN, levando a inibição de sua expressão ao longo da via de PI3K/AKT (Chun-Zhi et al., 2010).

PTEN é alvo também de miR-21 e miR-19a, ambos capazes de inibí-lo (Medina et al., 2010; Selcuklu et al., 2009; Takakura et al., 2008), contribuindo para a desregulação da via de PI3K/AKT. A diminuição de PTEN pode estimular a proliferação e levar a iniciação tumoral (Medina et al., 2010; Selcuklu et al., 2009). miR-21 foi encontrado mais expresso em diversos tipos de câncer (Cho, 2007; Frezzetti et al., 2011; Jazbutyte, Thum, 2010; Mitomo et al., 2008), incluindo CPT (He et al., 2005; Sheu et al., 2009; Sheu et al., 2010; Sun et al., 2013; Tetzlaff et al., 2007). Acredita-se que esse miRNA tenha um papel anti-apoptótico também por sua interferência na expressão de PDCD4, promovendo possivelmente o crescimento descontrolado, além de poder aumentar a capacidade de invasão de células tumorais em diversos tipos de câncer, inclusive no de tireoide (Frankel et al., 2008; Lu et al., 2008; Medina et al., 2010; Meng et al., 2006; Selcuklu et al., 2009).

MiR-146a é encontrado altamente expresso em CPT (He et al., 2005). Sua contribuição para o fenótipo tumoral pode se dar através de sua ligação ao PKCE (Protein kinase $\mathrm{C}$ epsilon), um importante modulador da via de MAPK (Zhang et al., 2013).

MiR-16 não foi encontrado mais expresso em CPT por outros grupos. Geralmente sua ausência está relacionada ao câncer (Calin et al., 2002). Esse miRNA foi um dos primeiros descritos como supressor de tumor e sua perda pode resultar no aumento da expressão de genes promotores de tumor, como BCL2, BMI1, CCND2 e CCND1, promovendo o crescimento celular e progressão tumoral (Calin et al., 2002; Chen et al., 2008; Cimmino et al., 2005; Klein et al., 2010).

A família do miR-200 foi encontrada mais expressa em linhagens celulares de câncer de tireoide apresentando as vias de MAPK e PI3K/AKT desreguladas (Cahill et al., 2006). A família deste miRNA também foi associada a tumores bem diferenciados de mama, apresentando maior expressão nesses tumores do que em tumores pouco diferenciados (Bockmeyer et al., 2011). De forma semelhante, tumores bem diferenciados de tireoide, como CPT e FTC, apresentaram maior expressão desta família de miRNAs quando comparados a carcinoma anaplásico de tireoide - tumor pouco diferenciado (Braun et al., 2010). A família do miR-200 é capaz de se ligar diretamente a ZEB1 e ZEB2 (dois fatores de transcrição capazes de controlar a transição epitelial-mesenquimal (EMT), e de inibir o gene E-cadherin 
(CDH1)), suprimindo a EMT (Gregory et al., 2008; Howe et al., 2012), que é um evento essencial para células cancerígenas ganharem motilidade, capacidade de invasão e de sobrevivência, aumentando o potencial metastático. Desta forma, a família do miR-200 parece ter papel fundamental na preservação do fenótipo epitelial, e a diminuição de sua expressão pode ser um evento potencializador da desdiferenciação, levando o câncer de tireoide a um fenótipo mais agressivo como o observado nos carcinomas anaplásicos (Braun et al., 2011).

MiR-20 tem papel importante na regulação da proliferação celular em câncer de pulmão (Hayashita et al., 2005.) e em leucemia linfocítica crônica (Venturini et al., 2007). Em tireoide não há dados na literatura sobre a relação deste miRNA e a presença de mutações. No entanto, em câncer de mama foi mostrado que miR-20 exerce um papel importante na proliferação e migração celular através de PTEN (Li et al., 2013).

O miR-92 faz parte do cluster miR-17-92, que também inclui os miRNAs, miR19a e miR20a/b (Lee, Dutta, 2009). Não há dados na literatura sobre a relação deste miRNA e a presença de mutações frequentes em CPT. No entanto, esse cluster foi encontrado superexpresso em linfomas (He et al., 2005; Ota et al, 2004; Rinaldi et al., 2007; Tagawa et al., 2007), câncer de pulmão (Hayashita et al., 2005; Matsubara et al., 2007) e outros (Volinia et al., 2006). O aumento da expressão do cluster miR17-92 foi capaz de acelerar o desenvolvimento de linfoma de células $B$ em camundongos superexpressando o oncogene c-myc (He et al., 2005). Um dos mecanismos que promove o aumento de expressão deste cluster é justamente mediado por c-Myc, que parece ser capaz de ativar a transcrição de pri-miR no núcleo (O’Donnell et al., 2005). Além de c-Myc, o cluster também pode ser ativado por E2Fs, que envolvem tanto fatores pro-apoptóticos quanto fatores capaz de promover proliferação (Sylvestre et al., 2007; Woods et al., 2007). Em contra partida miRNAs do cluster regulam negativamente alguns subtipos de E2Fs, contribuindo para o mecanismo complexo de regulação, que pode ou prevenir amplificações desreguladas, ou minimizar o potencial pró-apoptótico (Lee, Dutta, 2009).

MiR-31 foi encontrado superexpresso em câncer coloretal (Bandrés et al., 2006; Slaby et al., 2007; Wang et al., 2009) e em câncer de língua (Lee et al., 2013). No entanto, foi encontrado pouco expresso em câncer de mama (Lee et al., 2013), câncer gástrico (Lee et al., 2013) e câncer de pâncreas (Lee at al., 2013). Em tireoide, o miR-31 foi encontrado superexpresso em CPT (Nikiforova et al., 2008; 
Tetzlaff et al., 2007). Em nódulos tireoideanos benignos sua maior expressão foi relacionada com diminuição da expressão de CCND1, um regulador de ciclo celular, sugerindo papel anti-oncogênico (Ferraz et al., 2013). No entanto, Yip e colaboradores (2011) mostraram superexpressão deste miRNA e, formas mais agressivas de CPT. A superexpressão de miR-31 em câncer de colon foi correlacionada com progressão tumoral (Bandrés et al., 2006). Em contra partida, o aumento de expressão de miR-31 foi capaz de induzir parada de ciclo celular e apoptose, regredindo metástases pulmonares decorrentes de câncer de mama (Valastyan et al., 2011).

MiR-135a é capaz de promover crescimento e invasão em células de câncer colo-retal via MTSS1 (Zhou et al., 2012), induzir migração e invasão celular em câncer de mama através da ligação a HOXA10 (oncogene) (Chen Y et al., 2012; Liu et al., 2012). Em contra partida, miR-135a parece também ser capaz de inibir proliferação celular via JAK2 em câncer gástrico via c-MYC em carcinoma renal (Yamada et al., 2013; Wu et al., 2012). Em tireoide, miR-135b foi encontrado menos expresso em linhagem de CPT apresentando rearranjos em RET (Cahill et al., 2007). No entanto, foi encontrado superexpresso em amostras de CPT com extravasamento extratireoideano. A superexpressão também foi associada com maior tamanho tumoral, evidenciando um possível papel na determinação de características mais agressivas de CPT (Wang et al., 2013).

Concluímos que miRNAs podem constituir marcadores biológicos interessantes, passíveis de serem analisados em tecidos parafinados, mas que a identificação de marcadores fidedignos constitui tarefa complexa que depende de procedimentos criteriosos tanto para a seleção de amostras representativas do tumor quanto para a parte experimental inicial e de validação. 


\section{CONCLUSÕES}

Os resultados iniciais deste trabalho consistiram principalmente na seleção e caracterização de amostras de CPT, bem como na seleção e padronização de técnicas necessárias para a solução das questões propostas neste projeto.

As dificuldades para o trabalho com amostras parafinadas são conhecidas e tentamos analisar seu impacto nas análises de expressão gênica de miRNAs, bem como contornar estas dificuldades da melhor forma possível. A macro-dissecção se mostrou essencial, apresentando reprodutibilidade de dados de expressão gênica.

A escolha de métodos para extração de RNA, DNA, detecção de miRNAs e sequenciamento foram adequadas e padronizadas. Devido às limitações do sequenciamento por método Sanger quanto à sensibilidade para a detecção de mutações, avaliamos outros métodos para detecção de $B R A F^{V 600 E}$, método este baseado na utilização de anticorpos específicos para a detecção da mutação e ensaio por PCR em tempo real. Uma vez caracterizadas as amostras quanto a esta mutação, comparamos a expressão de miRNAs entre um grupo de amostras positivas e um grupo de amostras negativas para esta mutação.

Em resumo, podemos concluir:

- Padronizamos as técnicas de extração de DNA e RNA para a avaliação de expressão de miRNAs por PCR em tempo real e detecção de mutações frequentes em amostras parafinadas.

- Caracterizamos as amostras quanto à presença da mutação T1799A em BRAF $\left(B R A F^{V 600 E}\right)$ por sequenciamento tradicional, confirmando estes resultados com análises realizadas por imuno-histoquímica e PCR em tempo real. Os resultados de sequenciamento tradicional mostraram-se menos sensíveis, e associados com a quantidade de tumor presente nos cortes, ressaltando a importância da seleção cuidadosa da técnica de deteç̧ão para conclusões sobre a presença de mutações.

- Avaliamos a presença da translocação RET/PTC1 e RET/PTC3 nas amostras de CPT negativas para a mutação em BRAF utilizando a PCR em tempo real. Não obtivemos amplificação adequada para a detecção deste rearranjo. Este resultado pode ser considerado esperado dada a qualidade do RNA extraído (altamente fragmentado) a partir de amostras parafinadas. 
- Padronizamos reações para a detecção das mutações em KRAS nos códons 12/13 e códon 61, mas os resultados destes ensaios não nos permitiram caracterizar as amostras quanto a estas mutações. Poucas amostras apresentaram resultados de amplificação positiva, que permitissem o sequenciamento dos fragmentos. Consideramos que as amostras não possuíam qualidade de DNA suficiente para a reação com os primers utilizados.

- Avaliamos a expressão de miRNAs por PCR em tempo real em amostras parafinadas contendo tumor e amostras livres de tumor e verificamos uma associação entre características das amostras e os níveis de expressão obtidos. Observamos grande variabilidade quanto à expressão dos pacientes, um fato que deve ser levado em consideração quando miRNAs são estudados como biomarcadores.

- Comparamos por microarranjos de DNA a expressão de miRNAs em amostras positivas e negativas para $B R A F^{V 600 E}$. Encontramos diferencialmente expressos os miRNAs estudados no trabalho - miR-146b, miR221 e miR-222, mas também outros tries miRNAs envolvidos em processos e vias de sinalização semelhantes: miR146a, miR-21, miR-19a e miR-16. Avaliamos os resultados em um grupo adicional de amostras, mas constatamos grande variabilidade na expressão. Apenas o miR-146b parece apresentar, de fato, expressão alterada entre estes dois grupos de amostras. 


\section{REFERÊNCIAS ${ }^{2}$}

Abbosh $\mathrm{PH}$, Nephew KP. Multiple signaling pathways converge on beta-catenin in thyroid cancer. Thyroid. 2005;15(6):551-61.

Abrahamsen HN, Steiniche T, Nexo E, Hamilton-Dutoit SJ, Sorensen BS. Towards quantitative mRNA analysis in paraffin-embedded tissues using real-time reverse transcriptase-polymerase chain reaction: a methodological study on lymph nodes from melanoma patients. J Mol Diagn. 2003;5(1):34-41.

Abubaker J, Jehan Z, Bavi P, Sultana M, Al-Harbi S, Ibrahim $M$, et al. Clinicopathological analysis of papillary thyroid cancer with PIK3CA alterations in a Middle Eastern population. J Clin Endocrinol Metab. 2008;93(2):611-8.

Ambros V. MicroRNA pathways in flies and worms: growth, death, fat, stress, and timing. Cell. 2003;113(6):673-6.

Ashman LK. The biology of stem cell factor and its receptor C-kit. Int J Biochem Cell Biol. 1999;31(10):1037-51.

Bandrés E, Cubedo E, Agirre X, Malumbres R, Zárate R, Ramirez $N$, et al. Identification by Real-time PCR of 13 mature microRNAs differentially expressed in colorectal cancer and non-tumoral tissues. Mol Cancer. 2006;5:29.

Batsakixs JG, Nishiyama RH, Rich CR. Microlithiasis (calcospherites) and carcinoma of the thyroid gland. Arch Pathol. 1960;69:493-8.

Bentwich I, Avniel A, Karov Y, Aharonov R, Gilad S, Barad O, et al. Identification of hundreds of conserved and nonconserved human microRNAs. Nat Genet. 2005;37(7):766-70.

Bhattacharyya SN, Habermacher R, Martine U, Closs El, Filipowicz W. Relief of microRNA-mediated translational repression in human cells subjected to stress. Cell. 2006;125(6):1111-24.

Bockmeyer CL, Christgen M, Müller M, Fischer S, Ahrens P, Länger F, et al. MicroRNA profiles of healthy basal and luminal mammary epithelial cells are distinct and reflected in different breast cancer subtypes. Breast Cancer Res Treat. 2011;130(3):735-45.

Boelens MC, te Meerman GJ, Gibcus JH, Blokzijl T, Boezen HM, Timens W, et al. Microarray amplification bias: loss of $30 \%$ differentially expressed genes due to long probe - poly(A)-tail distances. BMC Genomics. 2007;8:277.

\footnotetext{
${ }^{2}$ De acordo com:

International Committee of Medical Journal Editors. [Internet]. Uniform requirements for manuscripts submitted to Biomedical Journal: sample references. [updated $2011 \mathrm{Jul}$ 15]. Available from: http://www.icmje.org
} 
Bohnsack MT, Czaplinski K, Gorlich D. Exportin 5 is a RanGTP-dependent dsRNAbinding protein that mediates nuclear export of pre-miRNAs. RNA. 2004;10(2):18591.

Bonin S, Hlubek F, Benhattar J, Denkert C, Dietel M, Fernandez PL, et al. Multicentre validation study of nucleic acids extraction from FFPE tissues. Virchows Arch. 2010;457(3):309-17.

Bonin S, Petrera F, Niccolini B, Stanta G. PCR analysis in archival postmortem tissues. Mol Pathol. 2003;56(3):184-6.

Borchert GM, Lanier W, Davidson BL. RNA polymerase III transcribes human microRNAs. Nat Struct Mol Biol. 2006;13(12):1097-101.

Bounacer A, Wicker R, Caillou B, Cailleux AF, Sarasin A, Schlumberger M, et al. High prevalence of activating ret proto-oncogene rearrangements, in thyroid tumors from patients who had received external radiation. Oncogene. 1997;15(11):1263-73.

Braun J, Hoang-Vu C, Dralle H, Hüttelmaier S. Downregulation of microRNAs directs the EMT and invasive potential of anaplastic thyroid carcinomas. Oncogene. 2010;29(29):4237-44.

Braun J, Hüttelmaier S. Pathogenic mechanisms of deregulated microRNA expression in thyroid carcinomas of follicular origin. Thyroid Res. 2011;4 Suppl 1:S1.

Cady B, Rossi R. An expanded view of risk-group definition in differentiated thyroid carcinoma. Surgery. 1988;104(6):947-53.

Cahill S, Smyth P, Denning K, Flavin R, Li J, Potratz A, et al. Effect of BRAFV600E mutation on transcription and post-transcriptional regulation in a papillary thyroid carcinoma model. Mol Cancer. 2007;6:21.

Cahill S, Smyth P, Finn SP, Denning K, Flavin R, O'Regan EM, et al. Effect of ret/PTC 1 rearrangement on transcription and post-transcriptional regulation in a papillary thyroid carcinoma model. Mol Cancer. 2006;5:70.

Calin GA, Croce CM. MicroRNA-cancer connection: the beginning of a new tale. Cancer Res. 2006;66(15):7390-4.

Calin GA, Dumitru CD, Shimizu M, Bichi R, Zupo S, Noch E, et al. Frequent deletions and down-regulation of micro- RNA genes miR15 and miR16 at 13q14 in chronic lymphocytic leukemia. Proc Natl Acad Sci U S A. 2002;99(24):15524-9.

Calin GA, Ferracin M, Cimmino A, Di Leva G, Shimizu M, Wojcik SE, et al. A MicroRNA signature associated with prognosis and progression in chronic lymphocytic leukemia. N Engl J Med. 2005;353(17):1793-801.

Calin GA, Sevignani C, Dumitru CD, Hyslop T, Noch E, Yendamuri S, et al. Human microRNA genes are frequently located at fragile sites and genomic regions involved in cancers. Proc Natl Acad Sci U S A. 2004;101(9):2999-3004. 
Capper D, Berghoff AS, Magerle M, Ilhan A, Wöhrer A, Hackl M, et al. Immunohistochemical testing of BRAF V600E status in 1,120 tumor tissue samples of patients with brain metastases. Acta Neuropathol. 2012;123(2):223-33.

Capper D, Preusser M, Habel A, Sahm F, Ackermann U, Schindler G, et al. Assessment of BRAF V600E mutation status by immunohistochemistry with a mutation-specific monoclonal antibody. Acta Neuropathol. 2011;122(1):11-9.

Carcangiu ML, Bianchi S. Diffuse sclerosing variant of papillary thyroid carcinoma. Clinicopathologic study of 15 cases. Am J Surg Pathol. 1989;13(12):1041-9.

Chan JA, Krichevsky AM, Kosik KS. MicroRNA-21 is an antiapoptotic factor in human glioblastoma cells. Cancer Res. 2005;65(14):6029-33.

Chan JK, Saw D. The grooved nucleus. A useful diagnostic criterion of papillary carcinoma of the thyroid. Am J Surg Pathol. 1986;10(10):672-9.

Chang F, Steelman LS, Lee JT, Shelton JG, Navolanic PM, Blalock WL, et al. Signal transduction mediated by the Ras/Raf/MEK/ERK pathway from cytokine receptors to transcription factors: potential targeting for therapeutic intervention. Leukemia. 2003;17(7):1263-93.

Chang YS, Yeh KT, Chang TJ, Chai C, Lu HC, Hsu NC, et al. Fast simultaneous detection of K-RAS mutations in colorectal cancer. BMC Cancer. 2009;9:179.

Chen RW, Bemis LT, Amato CM, Myint $\mathrm{H}$, Tran $\mathrm{H}$, Birks DK, et al. Truncation in CCND1 mRNA alters miR-16-1 regulation in mantle cell lymphoma. Blood. 2008;112(3):822-9.

Chen $\mathrm{Y}$, Zhang J, Wang $\mathrm{H}$, Zhao J, Xu C, Du Y, et al. miRNA-135a promotes breast cancer cell migration and invasion by targeting HOXA10. BMC Cancer. 2012;12:111.

Chen YT, Kitabayashi N, Zhou XK, Fahey TJ, Scognamiglio T. MicroRNA analysis as a potential diagnostic tool for papillary thyroid carcinoma. Mod Pathol. 2008;21(9):1139-46.

Cho WC. OncomiRs: the discovery and progress of microRNAs in cancers. Mol Cancer. 2007;6:60.

Chou CK, Chen RF, Chou FF, Chang HW, Chen YJ, Lee YF, et al. miR-146b is highly expressed in adult papillary thyroid carcinomas with high risk features including extrathyroidal invasion and the BRAF(V600E) mutation. Thyroid. 2010;20(5):489-94.

Chuang JC, Jones PA. Epigenetics and microRNAs. Pediatr Res. 2007;61(5 Pt 2):24R-9R.

Chun-Zhi Z, Lei H, An-Ling Z, Yan-Chao F, Xiao Y, Guang-Xiu W, et al. MicroRNA221 and microRNA-222 regulate gastric carcinoma cell proliferation and radioresistance by targeting PTEN. BMC Cancer. 2010;10:367. 
Ciafrè SA, Galardi S, Mangiola A, Ferracin M, Liu CG, Sabatino G, et al. Extensive modulation of a set of microRNAs in primary glioblastoma. Biochem Biophys Res Commun. 2005;334(4):1351-8.

Cimmino A, Calin GA, Fabbri M, lorio MV, Ferracin M, Shimizu M, et al. miR-15 and miR-16 induce apoptosis by targeting BCL2. Proc Natl Acad Sci U S A. 2005;102(39):13944-9.

Clément-Ziza M, Munnich A, Lyonnet S, Jaubert F, Besmond C. Stabilization of RNA during laser capture microdissection by performing experiments under argon atmosphere or using ethanol as a solvent in staining solutions. RNA. 2008;14(12):2698-704.

Davies H, Bignell GR, Cox C, Stephens P, Edkins S, Clegg S, et al. Mutations of the BRAF gene in human cancer. Nature. 2002;417(6892):949-54.

de Bruin EC, van de Pas S, Lips EH, van Eijk R, van der Zee MM, Lombaerts M, et al. Macrodissection versus microdissection of rectal carcinoma: minor influence of stroma cells to tumor cell gene expression profiles. BMC Genomics. 2005;6:142.

de la Chapelle A, Jazdzewski K. MicroRNAs in thyroid cancer. J Clin Endocrinol Metab. 2011;96(11):3326-36.

Di Leva G, Garofalo M, Croce CM. MicroRNAs in Cancer. Annu Rev Pathol. 2013.

Doench JG, Petersen CP, Sharp PA. siRNAs can function as miRNAs. Genes Dev. 2003;17(4):438-42.

Efanov A, Zanesi N, Nazaryan N, Santanam U, Palamarchuk A, Croce CM, et al. CD5+CD23+ leukemic cell populations in TCL1 transgenic mice show significantly increased proliferation and Akt phosphorylation. Leukemia. 2010;24(5):970-5.

Eis PS, Tam W, Sun L, Chadburn A, Li Z, Gomez MF, et al. Accumulation of miR-155 and BIC RNA in human B cell lymphomas. Proc Natl Acad Sci U $S$ A. 2005;102(10):3627-32.

Elisei R, Romei C, Vorontsova T, Cosci B, Veremeychik V, Kuchinskaya E, et al. RET/PTC rearrangements in thyroid nodules: studies in irradiated and not irradiated, malignant and benign thyroid lesions in children and adults. J Clin Endocrinol Metab. $2001 ; 86(7): 3211-6$.

Elisei R, Ugolini C, Viola D, Lupi C, Biagini A, Giannini R, et al. BRAF(V600E) mutation and outcome of patients with papillary thyroid carcinoma: a 15-year median follow-up study. J Clin Endocrinol Metab. 2008;93(10):3943-9.

Esapa CT, Johnson SJ, Kendall-Taylor P, Lennard TW, Harris PE. Prevalence of Ras mutations in thyroid neoplasia. Clin Endocrinol (Oxf). 1999;50(4):529-35.

Ezzat S, Zheng L, Kolenda J, Safarian A, Freeman JL, Asa SL. Prevalence of activating ras mutations in morphologically characterized thyroid nodules. Thyroid. 1996;6(5):409-16. 
Fabian MR, Sonenberg N, Filipowicz W. Regulation of mRNA translation and stability by microRNAs. Annu Rev Biochem. 2010;79:351-79.

Farragher SM, Tanney A, Kennedy RD, Paul Harkin D. RNA expression analysis from formalin fixed paraffin embedded tissues. Histochem Cell Biol. 2008;130(3):43545.

Feldman MY. Reactions of nucleic acids and nucleoproteins with formaldehyde. Prog Nucleic Acid Res Mol Biol. 1973;13:1-49.

Felli N, Fontana L, Pelosi E, Botta R, Bonci D, Facchiano F, et al. MicroRNAs 221 and 222 inhibit normal erythropoiesis and erythroleukemic cell growth via kit receptor down-modulation. Proc Natl Acad Sci U S A. 2005;102(50):18081-6.

Ferraz C, Lorenz S, Wojtas B, Bornstein SR, Paschke R, Eszlinger M. Inverse correlation of miRNA and cell cycle-associated genes suggests influence of miRNA on benign thyroid nodule tumorigenesis. J Clin Endocrinol Metab. 2013;98(1):E8-16.

Ferrer I, Armstrong J, Capellari S, Parchi P, Arzberger T, Bell J, et al. Effects of formalin fixation, paraffin embedding, and time of storage on DNA preservation in brain tissue: a BrainNet Europe study. Brain Pathol. 2007;17(3):297-303.

Frankel LB, Christoffersen NR, Jacobsen A, Lindow M, Krogh A, Lund AH. Programmed cell death 4 (PDCD4) is an important functional target of the microRNA miR-21 in breast cancer cells. J Biol Chem. 2008;283(2):1026-33.

Franzoni A, Dima M, D'Agostino M, Puppin C, Fabbro D, Loreto CD, et al. Prohibitin is overexpressed in papillary thyroid carcinomas bearing the BRAF(V600E) mutation. Thyroid. 2009;19(3):247-55.

Frattini M, Ferrario C, Bressan P, Balestra D, De Cecco L, Mondellini $P$, et al. Alternative mutations of BRAF, RET and NTRK1 are associated with similar but distinct gene expression patterns in papillary thyroid cancer. Oncogene. 2004;23(44):7436-40.

Frezzetti D, De Menna M, Zoppoli P, Guerra C, Ferraro A, Bello AM, et al. Upregulation of miR-21 by Ras in vivo and its role in tumor growth. Oncogene. $2011 ; 30(3): 275-86$.

Fugazzola L, Mannavola D, Cirello V, Vannucchi G, Muzza M, Vicentini L, et al. BRAF mutations in an Italian cohort of thyroid cancers. Clin Endocrinol (Oxf). 2004;61(2):239-43.

Fugazzola L, Puxeddu E, Avenia N, Romei C, Cirello V, Cavaliere A, et al. Correlation between B-RAFV600E mutation and clinico-pathologic parameters in papillary thyroid carcinoma: data from a multicentric Italian study and review of the literature. Endocr Relat Cancer. 2006;13(2):455-64.

Galardi S, Mercatelli N, Giorda E, Massalini S, Frajese GV, Ciafrè SA, et al. miR-221 and miR-222 expression affects the proliferation potential of human prostate carcinoma cell lines by targeting p27Kip1. J Biol Chem. 2007;282(32):23716-24. 
Garzon R, Fabbri M, Cimmino A, Calin GA, Croce CM. MicroRNA expression and function in cancer. Trends Mol Med. 2006;12(12):580-7.

Gilbert MT, Haselkorn T, Bunce M, Sanchez JJ, Lucas SB, Jewell LD, et al. The isolation of nucleic acids from fixed, paraffin-embedded tissues-which methods are useful when? PLoS One. 2007;2(6):e537.

Gillies JK, Lorimer IA. Regulation of p27Kip1 by miRNA 221/222 in glioblastoma. Cell Cycle. 2007;6(16):2005-9.

Giordano TJ, Kuick R, Thomas DG, Misek DE, Vinco M, Sanders D, et al. Molecular classification of papillary thyroid carcinoma: distinct BRAF, RAS, and RET/PTC mutation-specific gene expression profiles discovered by DNA microarray analysis. Oncogene. 2005;24(44):6646-56.

Godfrey TE, Kim SH, Chavira M, Ruff DW, Warren RS, Gray JW, et al. Quantitative mRNA expression analysis from formalin-fixed, paraffin-embedded tissues using $5^{\prime}$ nuclease quantitative reverse transcription-polymerase chain reaction. J Mol Diagn. 2000;2(2):84-91.

Gregory PA, Bert AG, Paterson EL, Barry SC, Tsykin A, Farshid G, et al. The miR200 family and miR-205 regulate epithelial to mesenchymal transition by targeting ZEB1 and SIP1. Nat Cell Biol. 2008;10(5):593-601.

Griffiths-Jones S. The microRNA Registry. Nucleic Acids Res. 2004;32(Database issue):D109-11.

Guerra A, Sapio MR, Marotta V, Campanile E, Rossi S, Forno I, et al. The primary occurrence of BRAF(V600E) is a rare clonal event in papillary thyroid carcinoma. $J$ Clin Endocrinol Metab. 2012;97(2):517-24.

Guigon CJ, Zhao L, Willingham MC, Cheng SY. PTEN deficiency accelerates tumour progression in a mouse model of thyroid cancer. Oncogene. 2009;28(4):509-17.

Guo H, Ingolia NT, Weissman JS, Bartel DP. Mammalian microRNAs predominantly act to decrease target mRNA levels. Nature. 2010;466(7308):835-40.

Hay ID, Bergstralh EJ, Goellner JR, Ebersold JR, Grant CS. Predicting outcome in papillary thyroid carcinoma: development of a reliable prognostic scoring system in a cohort of 1779 patients surgically treated at one institution during 1940 through 1989. Surgery. 1993;114(6):1050-7; discussion 7-8.

Hay ID, Grant CS, Taylor WF, McConahey WM. Ipsilateral lobectomy versus bilateral lobar resection in papillary thyroid carcinoma: a retrospective analysis of surgical outcome using a novel prognostic scoring system. Surgery. 1987;102(6):1088-95.

Hayashita Y, Osada H, Tatematsu Y, Yamada H, Yanagisawa K, Tomida S, et al. A polycistronic microRNA cluster, miR-17-92, is overexpressed in human lung cancers and enhances cell proliferation. Cancer Res. 2005;65(21):9628-32. 
He H, Jazdzewski K, Li W, Liyanarachchi S, Nagy R, Volinia S, et al. The role of microRNA genes in papillary thyroid carcinoma. Proc Natl Acad Sci U S A. 2005;102(52):19075-80.

He L, Thomson JM, Hemann MT, Hernando-Monge E, Mu D, Goodson S, et al. A microRNA polycistron as a potential human oncogene. Nature. 2005;435(7043):82833.

Hewitt SM, Lewis FA, Cao Y, Conrad RC, Cronin M, Danenberg KD, et al. Tissue handling and specimen preparation in surgical pathology: issues concerning the recovery of nucleic acids from formalin-fixed, paraffin-embedded tissue. Arch Pathol Lab Med. 2008;132(12):1929-35.

Howe EN, Cochrane DR, Richer JK. The miR-200 and miR-221/222 microRNA families: opposing effects on epithelial identity. J Mammary Gland Biol Neoplasia. 2012;17(1):65-77.

Hui A, How C, Ito E, Liu FF. Micro-RNAs as diagnostic or prognostic markers in human epithelial malignancies. BMC Cancer. 2011;11:500.

Hutvágner G, McLachlan J, Pasquinelli AE, Bálint E, Tuschl T, Zamore PD. A cellular function for the RNA-interference enzyme Dicer in the maturation of the let-7 small temporal RNA. Science. 2001;293(5531):834-8.

Hutvágner G, Zamore PD. A microRNA in a multiple-turnover RNAi enzyme complex. Science. 2002;297(5589):2056-60.

Hwang HW, Mendell JT. MicroRNAs in cell proliferation, cell death, and tumorigenesis. Br J Cancer. 2006;94(6):776-80.

Inoue Y, Tanaka K, Yokoe T, Saigusa S, Toiyama Y, Miki C, et al. Microdissection is essential for gene expression analysis of irradiated rectal cancer tissues. Oncol Rep. 2009;22(4):901-6.

Inui M, Martello G, Piccolo S. MicroRNA control of signal transduction. Nat Rev Mol Cell Biol. 2010;11(4):252-63.

lorio MV, Ferracin M, Liu CG, Veronese A, Spizzo R, Sabbioni S, et al. MicroRNA gene expression deregulation in human breast cancer. Cancer Res. 2005;65(16):7065-70.

Ito Y, Yoshida H, Maruo R, Morita S, Takano T, Hirokawa M, et al. BRAF mutation in papillary thyroid carcinoma in a Japanese population: its lack of correlation with highrisk clinicopathological features and disease-free survival of patients. Endocr J. 2009;56(1):89-97.

Jacob P, Kenigsberg Y, Zvonova I, Goulko G, Buglova E, Heidenreich WF, et al. Childhood exposure due to the Chernobyl accident and thyroid cancer risk in contaminated areas of Belarus and Russia. Br J Cancer. 1999;80(9):1461-9.

Jazbutyte V, Thum T. MicroRNA-21: from cancer to cardiovascular disease. Curr Drug Targets. 2010;11(8):926-35. 
Jazdzewski K, Murray EL, Franssila K, Jarzab B, Schoenberg DR, de la Chapelle A. Common SNP in pre-miR-146a decreases mature miR expression and predisposes to papillary thyroid carcinoma. Proc Natl Acad Sci U S A. 2008;105(20):7269-74.

Jhiang SM, Sagartz JE, Tong Q, Parker-Thornburg J, Capen CC, Cho JY, et al. Targeted expression of the ret/PTC1 oncogene induces papillary thyroid carcinomas. Endocrinology. 1996;137(1):375-8.

Jin L, Sebo TJ, Nakamura N, Qian X, Oliveira A, Majerus JA, et al. BRAF mutation analysis in fine needle aspiration (FNA) cytology of the thyroid. Diagn Mol Pathol. 2006;15(3):136-43.

Jo YS, Li S, Song JH, Kwon KH, Lee JC, Rha SY, et al. Influence of the BRAF V600E mutation on expression of vascular endothelial growth factor in papillary thyroid cancer. J Clin Endocrinol Metab. 2006;91(9):3667-70.

Johnson SM, Grosshans H, Shingara J, Byrom M, Jarvis R, Cheng A, et al. RAS is regulated by the let-7 microRNA family. Cell. 2005;120(5):635-47.

Karga H, Lee JK, Vickery AL, Thor A, Gaz RD, Jameson JL. Ras oncogene mutations in benign and malignant thyroid neoplasms. J Clin Endocrinol Metab. $1991 ; 73(4): 832-6$

Kim HK, Kim J, Korolevich S, Choi IJ, Kim CH, Munroe DJ, et al. Distinctions in gastric cancer gene expression signatures derived from laser capture microdissection versus histologic macrodissection. BMC Med Genomics. 2011;4:48.

Kim SJ, Lee KE, Myong JP, Park JH, Jeon YK, Min HS, et al. BRAF V600E mutation is associated with tumor aggressiveness in papillary thyroid cancer. World $\mathrm{J}$ Surg. $2012 ; 36(2): 310-7$

Kim SK, Kim DL, Han HS, Kim WS, Kim SJ, Moon WJ, et al. Pyrosequencing analysis for detection of a BRAFV600E mutation in an FNAB specimen of thyroid nodules. Diagn Mol Pathol. 2008;17(2):118-25.

Kim TY, Kim WB, Song JY, Rhee YS, Gong G, Cho YM, et al. The BRAF mutation is not associated with poor prognostic factors in Korean patients with conventional papillary thyroid microcarcinoma. Clin Endocrinol (Oxf). 2005;63(5):588-93.

Kimura ET, Nikiforova MN, Zhu Z, Knauf JA, Nikiforov YE, Fagin JA. High prevalence of BRAF mutations in thyroid cancer: genetic evidence for constitutive activation of the RET/PTC-RAS-BRAF signaling pathway in papillary thyroid carcinoma. Cancer Res. 2003;63(7):1454-7.

Kitamura Y, Hirotab S. Kit as a human oncogenic tyrosine kinase. Cell Mol Life Sci. 2004;61(23):2924-31.

Kitano M, Rahbari R, Patterson EE, Xiong Y, Prasad NB, Wang Y, et al. Expression profiling of difficult-to-diagnose thyroid histologic subtypes shows distinct expression profiles and identify candidate diagnostic microRNAs. Ann Surg Oncol. $2011 ; 18(12): 3443-52$. 
Klein U, Lia M, Crespo M, Siegel R, Shen Q, Mo T, et al. The DLEU2/miR-15a/16-1 cluster controls $\mathrm{B}$ cell proliferation and its deletion leads to chronic lymphocytic leukemia. Cancer Cell. 2010;17(1):28-40.

Klopfleisch R, Weiss AT, Gruber AD. Excavation of a buried treasure--DNA, mRNA, miRNA and protein analysis in formalin fixed, paraffin embedded tissues. Histol Histopathol. 2011;26(6):797-810.

Knauf JA, Kuroda H, Basu S, Fagin JA. RET/PTC-induced dedifferentiation of thyroid cells is mediated through $\mathrm{Y} 1062$ signaling through SHC-RAS-MAP kinase. Oncogene. 2003;22(28):4406-12.

Knauf JA, Sartor MA, Medvedovic M, Lundsmith E, Ryder M, Salzano M, et al. Progression of BRAF-induced thyroid cancer is associated with epithelialmesenchymal transition requiring concomitant MAP kinase and TGF $\beta$ signaling. Oncogene. 2011;30(28):3153-62.

Kondo T, Ezzat S, Asa SL. Pathogenetic mechanisms in thyroid follicular-cell neoplasia. Nat Rev Cancer. 2006;6(4):292-306.

Koperek O, Kornauth C, Capper D, Berghoff AS, Asari R, Niederle B, et al. Immunohistochemical detection of the BRAF V600E-mutated protein in papillary thyroid carcinoma. Am J Surg Pathol. 2012;36(6):844-50.

Krol J, Loedige I, Filipowicz W. The widespread regulation of microRNA biogenesis, function and decay. Nat Rev Genet. 2010;11(9):597-610.

Kumagai A, Namba H, Mitsutake N, Saenko VA, Ohtsuru A, Ito M, et al. Childhood thyroid carcinoma with BRAFT1799A mutation shows unique pathological features of poor differentiation. Oncol Rep. 2006;16(1):123-6.

Largey JS, Meltzer SJ, Yin J, Norris K, Sauk JJ, Archibald DW. Loss of heterozygosity of p53 in oral cancers demonstrated by the polymerase chain reaction. Cancer. 1993;71(6):1933-7.

Lau NC, Lim LP, Weinstein EG, Bartel DP. An abundant class of tiny RNAs with probable regulatory roles in Caenorhabditis elegans. Science. 2001;294(5543):85862.

Lawrie $\mathrm{CH}$, Soneji S, Marafioti T, Cooper CD, Palazzo S, Paterson JC, et al. MicroRNA expression distinguishes between germinal center B cell-like and activated $B$ cell-like subtypes of diffuse large B cell lymphoma. Int J Cancer. 2007;121(5):115661.

le Sage C, Nagel R, Egan DA, Schrier M, Mesman E, Mangiola A, et al. Regulation of the p27(Kip1) tumor suppressor by miR-221 and miR-222 promotes cancer cell proliferation. EMBO J. 2007;26(15):3699-708.

Lee HJ, Choi J, Hwang TS, Shong YK, Hong SJ, Gong G. Detection of BRAF mutations in thyroid nodules by allele-specific PCR using a dual priming oligonucleotide system. Am J Clin Pathol. 2010;133(5):802-8. 
Lee RC, Ambros V. An extensive class of small RNAs in Caenorhabditis elegans. Science. 2001;294(5543):862-4.

Lee RC, Feinbaum RL, Ambros V. The C. elegans heterochronic gene lin-4 encodes small RNAs with antisense complementarity to lin-14. Cell. 1993;75(5):843-54.

Lee ST, Kim SW, Ki CS, Jang JH, Shin JH, Oh YL, et al. Clinical implication of highly sensitive detection of the BRAF V600E mutation in fine-needle aspirations of thyroid nodules: a comparative analysis of three molecular assays in 4585 consecutive cases in a BRAF V600E mutation-prevalent area. J Clin Endocrinol Metab. 2012;97(7):2299-306.

Lee Y, Ahn C, Han J, Choi H, Kim J, Yim J, et al. The nuclear RNase III Drosha initiates microRNA processing. Nature. 2003;425(6956):415-9.

Lee $\mathrm{Y}$, Jeon K, Lee JT, Kim S, Kim VN. MicroRNA maturation: stepwise processing and subcellular localization. EMBO J. 2002;21(17):4663-70.

Lee $\mathrm{Y}$, Kim M, Han J, Yeom KH, Lee S, Baek SH, et al. MicroRNA genes are transcribed by RNA polymerase II. EMBO J. 2004;23(20):4051-60.

Lee YS, Dutta A. MicroRNAs in cancer. Annu Rev Pathol. 2009;4:199-227.

Leite KR, Canavez JM, Reis ST, Tomiyama AH, Piantino CB, Sañudo A, et al. miRNA analysis of prostate cancer by quantitative real time PCR: comparison between formalin-fixed paraffin embedded and fresh-frozen tissue. Urol Oncol. $2011 ; 29(5): 533-7$.

Lewis F, Maughan NJ, Smith V, Hillan K, Quirke P. Unlocking the archive--gene expression in paraffin-embedded tissue. J Pathol. 2001;195(1):66-71.

Li D, Inytskyy $Y$, Kovalchuk A, Khachigian LM, Bronson RT, Wang B, et al. Crucial role for early growth response-1 in the transcriptional regulation of miR-20b in breast cancer. Oncotarget. 2013;4(9):1373-87.

Liang J, Zubovitz J, Petrocelli T, Kotchetkov R, Connor MK, Han K, et al. PKB/Akt phosphorylates p27, impairs nuclear import of p27 and opposes p27-mediated G1 arrest. Nat Med. 2002;8(10):1153-60.

Lim LP, Lau NC, Garrett-Engele P, Grimson A, Schelter JM, Castle J, et al. Microarray analysis shows that some microRNAs downregulate large numbers of target mRNAs. Nature. 2005;433(7027):769-73.

Lima J, Trovisco V, Soares P, Máximo V, Magalhães J, Salvatore G, et al. BRAF mutations are not a major event in post-Chernobyl childhood thyroid carcinomas. J Clin Endocrinol Metab. 2004;89(9):4267-71.

Liu J, Carmell MA, Rivas FV, Marsden CG, Thomson JM, Song JJ, et al. Argonaute2 is the catalytic engine of mammalian RNAi. Science. 2004;305(5689):1437-41. 
Liu RT, Chen YJ, Chou FF, Li CL, Wu WL, Tsai PC, et al. No correlation between BRAFV600E mutation and clinicopathological features of papillary thyroid carcinomas in Taiwan. Clin Endocrinol (Oxf). 2005;63(4):461-6.

Liu S, Guo W, Shi J, Li N, Yu X, Xue J, et al. MicroRNA-135a contributes to the development of portal vein tumor thrombus by promoting metastasis in hepatocellular carcinoma. J Hepatol. 2012;56(2):389-96.

Liu Z, Hou P, Ji M, Guan H, Studeman K, Jensen K, et al. Highly prevalent genetic alterations in receptor tyrosine kinases and phosphatidylinositol 3-kinase/akt and mitogen-activated protein kinase pathways in anaplastic and follicular thyroid cancers. J Clin Endocrinol Metab. 2008;93(8):3106-16.

Livak KJ, Schmittgen TD. Analysis of relative gene expression data using real-time quantitative PCR and the 2(-Delta Delta C(T)) Method. Methods. 2001;25(4):402-8.

LiVolsi VA. Papillary neoplasms of the thyroid. Pathologic and prognostic features. Am J Clin Pathol. 1992;97(3):426-34.

Llave C, Xie Z, Kasschau KD, Carrington JC. Cleavage of Scarecrow-like mRNA targets directed by a class of Arabidopsis miRNA. Science. 2002;297(5589):2053-6.

Lodewijk L, Prins AM, Kist JW, Valk GD, Kranenburg O, Rinkes IH, et al. The value of miRNA in diagnosing thyroid cancer: a systematic review. Cancer Biomark. 2012;11(6):229-38.

Lu J, Getz G, Miska EA, Alvarez-Saavedra E, Lamb J, Peck D, et al. MicroRNA expression profiles classify human cancers. Nature. 2005;435(7043):834-8.

Lu Z, Liu M, Stribinskis V, Klinge CM, Ramos KS, Colburn NH, et al. MicroRNA-21 promotes cell transformation by targeting the programmed cell death 4 gene. Oncogene. 2008;27(31):4373-9.

Lund E, Güttinger S, Calado A, Dahlberg JE, Kutay U. Nuclear export of microRNA precursors. Science. 2004;303(5654):95-8.

Lupi C, Giannini R, Ugolini C, Proietti A, Berti P, Minuto M, et al. Association of BRAF V600E mutation with poor clinicopathological outcomes in 500 consecutive cases of papillary thyroid carcinoma. J Clin Endocrinol Metab. 2007;92(11):4085-90.

Ma Z, Lui WO, Fire A, Dadras SS. Profiling and discovery of novel miRNAs from formalin-fixed, paraffin-embedded melanoma and nodal specimens. J Mol Diagn. 2009;11(5):420-9.

MacCorkle RA, Tan TH. Mitogen-activated protein kinases in cell-cycle control. Cell Biochem Biophys. 2005;43(3):451-61.

Malashicheva AB, Kisliakova TV, Pospelov VA. [G1 block of the cell cycle during differentiation of F9 cells correlates with accumulation of inhibitors of the activity of cyclin-kinase complexes of proteins p21/Waf1 and p27/Kip]. Tsitologiia. 2002;44(7):649-55. 
Manenti G, Pilotti S, Re FC, Della Porta G, Pierotti MA. Selective activation of ras oncogenes in follicular and undifferentiated thyroid carcinomas. Eur $\mathrm{J}$ Cancer. 1994;30A(7):987-93.

Marini F, Luzi E, Brandi ML. MicroRNA Role in Thyroid Cancer Development. J Thyroid Res. 2011;2011:407123.

Marotta V, Guerra A, Sapio MR, Vitale M. RET/PTC rearrangement in benign and malignant thyroid diseases: a clinical standpoint. Eur J Endocrinol. 2011;165(4):499507.

Masuda N, Ohnishi T, Kawamoto S, Monden M, Okubo K. Analysis of chemical modification of RNA from formalin-fixed samples and optimization of molecular biology applications for such samples. Nucleic Acids Res. 1999;27(22):4436-43.

Matsubara H, Takeuchi T, Nishikawa E, Yanagisawa K, Hayashita Y, Ebi H, et al. Apoptosis induction by antisense oligonucleotides against miR-17-5p and miR-20a in lung cancers overexpressing miR-17-92. Oncogene. 2007;26(41):6099-105.

Mattie MD, Benz CC, Bowers J, Sensinger K, Wong L, Scott GK, et al. Optimized high-throughput microRNA expression profiling provides novel biomarker assessment of clinical prostate and breast cancer biopsies. Mol Cancer. 2006;5:24.

Mazeh H, Mizrahi I, Halle D, llyayev N, Stojadinovic A, Trink B, et al. Development of a microRNA-based molecular assay for the detection of papillary thyroid carcinoma in aspiration biopsy samples. Thyroid. 2011;21(2):111-8.

Medina PP, Nolde M, Slack FJ. OncomiR addiction in an in vivo model of microRNA21-induced pre-B-cell lymphoma. Nature. 2010;467(7311):86-90.

Melillo RM, Castellone MD, Guarino V, De Falco V, Cirafici AM, Salvatore G, et al. The RET/PTC-RAS-BRAF linear signaling cascade mediates the motile and mitogenic phenotype of thyroid cancer cells. J Clin Invest. 2005;115(4):1068-81.

Meng F, Henson R, Lang M, Wehbe H, Maheshwari S, Mendell JT, et al. Involvement of human micro-RNA in growth and response to chemotherapy in human cholangiocarcinoma cell lines. Gastroenterology. 2006;130(7):2113-29.

Mercer KE, Pritchard CA. Raf proteins and cancer: B-Raf is identified as a mutational target. Biochim Biophys Acta. 2003;1653(1):25-40.

Mesa C, Mirza M, Mitsutake N, Sartor M, Medvedovic M, Tomlinson C, et al. Conditional activation of RET/PTC3 and BRAFV600E in thyroid cells is associated with gene expression profiles that predict a preferential role of BRAF in extracellular matrix remodeling. Cancer Res. 2006;66(13):6521-9.

Michael MZ, O' Connor SM, van Holst Pellekaan NG, Young GP, James RJ. Reduced accumulation of specific microRNAs in colorectal neoplasia. Mol Cancer Res. 2003;1(12):882-91. 
Michel C, Desdouets C, Sacre-Salem B, Gautier JC, Roberts R, Boitier E. Liver gene expression profiles of rats treated with clofibric acid: comparison of whole liver and laser capture microdissected liver. Am J Pathol. 2003;163(6):2191-9.

Milbury CA, Li J, Makrigiorgos GM. PCR-based methods for the enrichment of minority alleles and mutations. Clin Chem. 2009;55(4):632-40.

Mitomo S, Maesawa C, Ogasawara S, Iwaya T, Shibazaki M, Yashima-Abo A, et al. Downregulation of miR-138 is associated with overexpression of human telomerase reverse transcriptase protein in human anaplastic thyroid carcinoma cell lines. Cancer Sci. 2008;99(2):280-6.

Mitsutake N, Knauf JA, Mitsutake S, Mesa C, Zhang L, Fagin JA. Conditional BRAFV600E expression induces DNA synthesis, apoptosis, dedifferentiation, and chromosomal instability in thyroid PCCL3 cells. Cancer Res. 2005;65(6):2465-73.

Miura K, Bowman ED, Simon R, Peng AC, Robles Al, Jones RT, et al. Laser capture microdissection and microarray expression analysis of lung adenocarcinoma reveals tobacco smoking- and prognosis-related molecular profiles. Cancer Res. 2002;62(11):3244-50.

Miyakawa M, Tsushima T, Murakami H, Wakai K, Isozaki O, Takano K. Increased expression of phosphorylated p70S6 kinase and Akt in papillary thyroid cancer tissues. Endocr J. 2003;50(1):77-83.

Motoi N, Sakamoto A, Yamochi T, Horiuchi H, Motoi T, Machinami R. Role of ras mutation in the progression of thyroid carcinoma of follicular epithelial origin. Pathol Res Pract. 2000;196(1):1-7.

Mulero-Navarro S, Esteller M. Epigenetic biomarkers for human cancer: the time is now. Crit Rev Oncol Hematol. 2008;68(1):1-11.

Murugan AK, Xing M. Anaplastic thyroid cancers harbor novel oncogenic mutations of the ALK gene. Cancer Res. 2011;71(13):4403-11.

Nakanishi H, Taccioli C, Palatini J, Fernandez-Cymering C, Cui R, Kim T, et al. Loss of miR-125b-1 contributes to head and neck cancer development by dysregulating TACSTD2 and MAPK pathway. Oncogene. 2013.

Namba H, Rubin SA, Fagin JA. Point mutations of ras oncogenes are an early event in thyroid tumorigenesis. Mol Endocrinol. 1990;4(10):1474-9.

Natali PG, Berlingieri MT, Nicotra MR, Fusco A, Santoro E, Bigotti A, et al. Transformation of thyroid epithelium is associated with loss of c-kit receptor. Cancer Res. 1995;55(8):1787-91.

Negrini M, Ferracin M, Sabbioni S, Croce CM. MicroRNAs in human cancer: from research to therapy. J Cell Sci. 2007;120(Pt 11):1833-40.

Nikiforov YE, Ohori NP, Hodak SP, Carty SE, LeBeau SO, Ferris RL, et al. Impact of mutational testing on the diagnosis and management of patients with cytologically 
indeterminate thyroid nodules: a prospective analysis of 1056 FNA samples. J Clin Endocrinol Metab. 2011;96(11):3390-7.

Nikiforov YE, Rowland JM, Bove KE, Monforte-Munoz H, Fagin JA. Distinct pattern of ret oncogene rearrangements in morphological variants of radiation-induced and sporadic thyroid papillary carcinomas in children. Cancer Res. 1997;57(9):1690-4.

Nikiforov YE. Thyroid carcinoma: molecular pathways and therapeutic targets. Mod Pathol. 2008;21 Suppl 2:S37-43.

Nikiforova MN, Ciampi R, Salvatore G, Santoro M, Gandhi M, Knauf JA, et al. Low prevalence of BRAF mutations in radiation-induced thyroid tumors in contrast to sporadic papillary carcinomas. Cancer Lett. 2004;209(1):1-6.

Nikiforova MN, Kimura ET, Gandhi M, Biddinger PW, Knauf JA, Basolo F, et al. BRAF mutations in thyroid tumors are restricted to papillary carcinomas and anaplastic or poorly differentiated carcinomas arising from papillary carcinomas. $J$ Clin Endocrinol Metab. 2003;88(11):5399-404.

Nikiforova MN, Tseng GC, Steward D, Diorio D, Nikiforov YE. MicroRNA expression profiling of thyroid tumors: biological significance and diagnostic utility. J Clin Endocrinol Metab. 2008;93(5):1600-8.

Nowicki TS, Kummer NT, lacob C, Suslina N, Schaefer S, Schantz S, et al. Inhibition of UPAR and UPA reduces invasion in papillary thyroid carcinoma cells. Laryngoscope. 2010;120(7):1383-90.

Nowicki TS, Zhao H, Darzynkiewicz Z, Moscatello A, Shin E, Schantz S, et al. Downregulation of uPAR inhibits migration, invasion, proliferation, FAK/PI3K/Akt signaling and induces senescence in papillary thyroid carcinoma cells. Cell Cycle. 2011;10(1):100-7.

Nucera C, Lawler J, Parangi S. BRAF(V600E) and microenvironment in thyroid cancer: a functional link to drive cancer progression. Cancer Res. 2011;71(7):241722.

Nucera C, Porrello A, Antonello ZA, Mekel M, Nehs MA, Giordano TJ, et al. BRaf(V600E) and thrombospondin-1 promote thyroid cancer progression. Proc Natl Acad Sci U S A. 2010;107(23):10649-54.

Nygaard V, Løland A, Holden M, Langaas M, Rue H, Liu F, et al. Effects of mRNA amplification on gene expression ratios in cDNA experiments estimated by analysis of variance. BMC Genomics. 2003;4(1):11.

O'Donnell KA, Wentzel EA, Zeller KI, Dang CV, Mendell JT. c-Myc-regulated microRNAs modulate E2F1 expression. Nature. 2005;435(7043):839-43.

Okada $\mathrm{H}$, Kohanbash $\mathrm{G}$, Lotze MT. MicroRNAs in immune regulation--opportunities for cancer immunotherapy. Int J Biochem Cell Biol. 2010;42(8):1256-61.

Oler G, Camacho CP, Hojaij FC, Michaluart P, Riggins GJ, Cerutti JM. Gene expression profiling of papillary thyroid carcinoma identifies transcripts correlated with 
BRAF mutational status and lymph node metastasis. Clin Cancer Res. 2008;14(15):4735-42.

Osaki M, Takeshita F, Ochiya T. MicroRNAs as biomarkers and therapeutic drugs in human cancer. Biomarkers. 2008;13(7):658-70.

Ota A, Tagawa H, Karnan S, Tsuzuki S, Karpas A, Kira S, et al. Identification and characterization of a novel gene, C13orf25, as a target for 13q31-q32 amplification in malignant lymphoma. Cancer Res. 2004;64(9):3087-95.

Pallante $\mathrm{P}$, Visone R, Ferracin M, Ferraro A, Berlingieri MT, Troncone $\mathrm{G}$, et al. MicroRNA deregulation in human thyroid papillary carcinomas. Endocr Relat Cancer. 2006;13(2):497-508.

Palona I, Namba H, Mitsutake N, Starenki D, Podtcheko A, Sedliarou I, et al. BRAFV600E promotes invasiveness of thyroid cancer cells through nuclear factor kappaB activation. Endocrinology. 2006;147(12):5699-707.

Park JY, Kim WY, Hwang TS, Lee SS, Kim H, Han HS, et al. BRAF and RAS mutations in follicular variants of papillary thyroid carcinoma. Endocr Pathol. 2013;24(2):69-76.

Pasquali D, Santoro A, Bufo P, Conzo G, Deery WJ, Renzullo A, et al. Upregulation of endocrine gland-derived vascular endothelial growth factor in papillary thyroid cancers displaying infiltrative patterns, lymph node metastases, and BRAF mutation. Thyroid. 2011;21(4):391-9.

Pavelić J, Gall-Troselj K, Bosnar MH, Kardum MM, Pavelić K. PCR amplification of DNA from archival specimens. A methodological approach. Neoplasma. 1996;43(2):75-81

Pekarsky Y, Santanam U, Cimmino A, Palamarchuk A, Efanov A, Maximov V, et al. Tcl1 expression in chronic lymphocytic leukemia is regulated by miR-29 and miR181. Cancer Res. 2006;66(24):11590-3.

Petersen GM, Boffetta P. Carcinogenesis of pancreatic cancer: challenges, collaborations, progress. Mol Carcinog. 2012;51(1):1-2.

Pylayeva-Gupta Y, Grabocka E, Bar-Sagi D. RAS oncogenes: weaving a tumorigenic web. Nat Rev Cancer. 2011;11(11):761-74.

Rabes HM, Demidchik EP, Sidorow JD, Lengfelder E, Beimfohr C, Hoelzel D, et al. Pattern of radiation-induced RET and NTRK1 rearrangements in 191 post-chernobyl papillary thyroid carcinomas: biological, phenotypic, and clinical implications. Clin Cancer Res. 2000;6(3):1093-103.

Reinhart BJ, Slack FJ, Basson M, Pasquinelli AE, Bettinger JC, Rougvie AE, et al. The 21-nucleotide let-7 RNA regulates developmental timing in Caenorhabditis elegans. Nature. 2000;403(6772):901-6. 
Ricarte-Filho JC, Fuziwara CS, Yamashita AS, Rezende E, da-Silva MJ, Kimura ET. Effects of let-7 microRNA on Cell Growth and Differentiation of Papillary Thyroid Cancer. Transl Oncol. 2009;2(4):236-41.

Riesco-Eizaguirre G, Rodríguez I, De la Vieja A, Costamagna E, Carrasco N, Nistal $\mathrm{M}$, et al. The BRAFV600E oncogene induces transforming growth factor beta secretion leading to sodium iodide symporter repression and increased malignancy in thyroid cancer. Cancer Res. 2009;69(21):8317-25.

Riesco-Eizaguirre G, Santisteban P. New insights in thyroid follicular cell biology and its impact in thyroid cancer therapy. Endocr Relat Cancer. 2007;14(4):957-77.

Rinaldi A, Poretti G, Kwee I, Zucca E, Catapano CV, Tibiletti MG, et al. Concomitant MYC and microRNA cluster miR-17-92 (C13orf25) amplification in human mantle cell lymphoma. Leuk Lymphoma. 2007;48(2):410-2.

Ringel MD, Hayre N, Saito J, Saunier B, Schuppert F, Burch H, et al. Overexpression and overactivation of Akt in thyroid carcinoma. Cancer Res. 2001;61(16):6105-11.

Rivera M, Ricarte-Filho J, Knauf J, Shaha A, Tuttle M, Fagin JA, et al. Molecular genotyping of papillary thyroid carcinoma follicular variant according to its histological subtypes (encapsulated vs infiltrative) reveals distinct BRAF and RAS mutation patterns. Mod Pathol. 2010;23(9):1191-200.

Robbins J, Merino MJ, Boice JD, Ron E, Ain KB, Alexander HR, et al. Thyroid cancer: a lethal endocrine neoplasm. Ann Intern Med. 1991;115(2):133-47.

Robinson MJ, Cobb MH. Mitogen-activated protein kinase pathways. Curr Opin Cell Biol. 1997;9(2):180-6.

Rosai J. Papillary carcinoma. Monogr Pathol. 1993(35):138-65.

Russo A, Bazan V, Agnese V, Rodolico V, Gebbia N. Prognostic and predictive factors in colorectal cancer: Kirsten Ras in CRC (RASCAL) and TP53CRC collaborative studies. Ann Oncol. 2005;16 Suppl 4:iv44-9.

Sabarense CM, Rocha KS, Rosa DD, Martins JH, Pereira MM, Silva FF, et al. A new computational method for hepatic fat microvesicles counting in histological study in rats. Biochem Biophys Res Commun. 2012;418(2):284-9.

Saji M, Ringel MD. The PI3K-Akt-mTOR pathway in initiation and progression of thyroid tumors. Mol Cell Endocrinol. 2010;321(1):20-8.

Salvatore D, Barone MV, Salvatore G, Melillo RM, Chiappetta G, Mineo A, et al. Tyrosines 1015 and 1062 are in vivo autophosphorylation sites in ret and ret-derived oncoproteins. J Clin Endocrinol Metab. 2000;85(10):3898-907.

Santoro M, Carlomagno F, Hay ID, Herrmann MA, Grieco M, Melillo R, et al. Ret oncogene activation in human thyroid neoplasms is restricted to the papillary cancer subtype. J Clin Invest. 1992;89(5):1517-22. 
Santoro M, Chiappetta G, Cerrato A, Salvatore D, Zhang L, Manzo G, et al. Development of thyroid papillary carcinomas secondary to tissue-specific expression of the RET/PTC1 oncogene in transgenic mice. Oncogene. 1996;12(8):1821-6.

Santoro M, Dathan NA, Berlingieri MT, Bongarzone I, Paulin C, Grieco M, et al. Molecular characterization of RET/PTC3; a novel rearranged version of the RETproto-oncogene in a human thyroid papillary carcinoma. Oncogene. 1994;9(2):509-16.

Santoro M, Melillo RM, Fusco A. RET/PTC activation in papillary thyroid carcinoma: European Journal of Endocrinology Prize Lecture. Eur $\mathrm{J}$ Endocrinol. 2006;155(5):645-53.

Sapio MR, Guerra A, Posca D, Limone PP, Deandrea M, Motta M, et al. Combined analysis of galectin-3 and BRAFV600E improves the accuracy of fine-needle aspiration biopsy with cytological findings suspicious for papillary thyroid carcinoma. Endocr Relat Cancer. 2007;14(4):1089-97.

Sapio MR, Posca D, Raggioli A, Guerra A, Marotta V, Deandrea M, et al. Detection of RET/PTC, TRK and BRAF mutations in preoperative diagnosis of thyroid nodules with indeterminate cytological findings. Clin Endocrinol (Oxf). 2007;66(5):678-83.

Scheidl SJ, Nilsson S, Kalén M, Hellström M, Takemoto M, Håkansson J, et al. mRNA expression profiling of laser microbeam microdissected cells from slender embryonic structures. Am J Pathol. 2002;160(3):801-13.

Schwertheim S, Sheu SY, Worm K, Grabellus F, Schmid KW. Analysis of deregulated miRNAs is helpful to distinguish poorly differentiated thyroid carcinoma from papillary thyroid carcinoma. Horm Metab Res. 2009;41(6):475-81.

Scott GK, Goga A, Bhaumik D, Berger CE, Sullivan CS, Benz CC. Coordinate suppression of ERBB2 and ERBB3 by enforced expression of micro-RNA miR-125a or miR-125b. J Biol Chem. 2007;282(2):1479-86.

Selcuklu SD, Donoghue MT, Spillane C. miR-21 as a key regulator of oncogenic processes. Biochem Soc Trans. 2009;37(Pt 4):918-25.

Sherman SI. Thyroid carcinoma. Lancet. 2003;361(9356):501-11.

Sheu SY, Grabellus F, Schwertheim S, Handke S, Worm K, Schmid KW. Lack of correlation between BRAF V600E mutational status and the expression profile of a distinct set of miRNAs in papillary thyroid carcinoma. Horm Metab Res. 2009;41(6):482-7.

Sheu SY, Grabellus F, Schwertheim S, Worm K, Broecker-Preuss M, Schmid KW. Differential miRNA expression profiles in variants of papillary thyroid carcinoma and encapsulated follicular thyroid tumours. Br J Cancer. 2010;102(2):376-82.

Shin I, Yakes FM, Rojo F, Shin NY, Bakin AV, Baselga J, et al. PKB/Akt mediates cell-cycle progression by phosphorylation of p27(Kip1) at threonine 157 and modulation of its cellular localization. Nat Med. 2002;8(10):1145-52. 
Shinohara M, Chung YJ, Saji M, Ringel MD. AKT in thyroid tumorigenesis and progression. Endocrinology. 2007;148(3):942-7.

Siebolts U, Varnholt H, Drebber U, Dienes HP, Wickenhauser C, Odenthal M. Tissues from routine pathology archives are suitable for microRNA analyses by quantitative PCR. J Clin Pathol. 2009;62(1):84-8.

Siegel R, Ward E, Brawley O, Jemal A. Cancer statistics, 2011: the impact of eliminating socioeconomic and racial disparities on premature cancer deaths. CA Cancer J Clin. 2011;61(4):212-36.

Sithanandam G, Druck T, Cannizzaro LA, Leuzzi G, Huebner K, Rapp UR. B-raf and a B-raf pseudogene are located on 7q in man. Oncogene. 1992;7(4):795-9.

Slaby O, Svoboda M, Fabian P, Smerdova T, Knoflickova D, Bednarikova M, et al. Altered expression of miR-21, miR-31, miR-143 and miR-145 is related to clinicopathologic features of colorectal cancer. Oncology. 2007;72(5-6):397-402.

Small EM, O'Rourke JR, Moresi V, Sutherland LB, McAnally J, Gerard RD, et al. Regulation of PI3-kinase/Akt signaling by muscle-enriched microRNA-486. Proc Natl Acad Sci U S A. 2010;107(9):4218-23.

Soares P, Trovisco V, Rocha AS, Lima J, Castro P, Preto A, et al. BRAF mutations and RET/PTC rearrangements are alternative events in the etiopathogenesis of PTC. Oncogene. 2003;22(29):4578-80.

Sonkoly E, Ståhle M, Pivarcsi A. MicroRNAs and immunity: novel players in the regulation of normal immune function and inflammation. Semin Cancer Biol. 2008;18(2):131-40.

Suarez HG, du Villard JA, Severino M, Caillou B, Schlumberger M, Tubiana M, et al. Presence of mutations in all three ras genes in human thyroid tumors. Oncogene. 1990;5(4):565-70.

Suda K, Tomizawa K, Mitsudomi T. Biological and clinical significance of KRAS mutations in lung cancer: an oncogenic driver that contrasts with EGFR mutation. Cancer Metastasis Rev. 2010;29(1):49-60.

Sugg SL, Ezzat S, Rosen IB, Freeman JL, Asa SL. Distinct multiple RET/PTC gene rearrangements in multifocal papillary thyroid neoplasia. J Clin Endocrinol Metab. $1998 ; 83(11): 4116-22$.

Sugiyama Y, Sugiyama K, Hirai Y, Akiyama F, Hasumi K. Microdissection is essential for gene expression profiling of clinically resected cancer tissues. Am J Clin Pathol. 2002;117(1):109-16.

Sun $Y$, Yu S, Liu Y, Wang F, Xiao H. Expression of miRNAs in Papillary Thyroid Carcinomas Is Associated with BRAF Mutation and Clinicopathological Features in Chinese Patients. Int J Endocrinol. 2013;2013:128735.

Sylvestre Y, De Guire V, Querido E, Mukhopadhyay UK, Bourdeau V, Major F, et al. An E2F/miR-20a autoregulatory feedback loop. J Biol Chem. 2007;282(4):2135-43. 
Tagawa H, Karube K, Tsuzuki S, Ohshima K, Seto M. Synergistic action of the microRNA-17 polycistron and Myc in aggressive cancer development. Cancer Sci. 2007;98(9):1482-90.

Takakura S, Mitsutake N, Nakashima M, Namba H, Saenko VA, Rogounovitch TI, et al. Oncogenic role of miR-17-92 cluster in anaplastic thyroid cancer cells. Cancer Sci. 2008;99(6):1147-54.

Takamizawa J, Konishi H, Yanagisawa K, Tomida S, Osada H, Endoh $\mathrm{H}$, et al. Reduced expression of the let-7 microRNAs in human lung cancers in association with shortened postoperative survival. Cancer Res. 2004;64(11):3753-6.

Tallini G, Santoro M, Helie M, Carlomagno F, Salvatore G, Chiappetta G, et al. RET/PTC oncogene activation defines a subset of papillary thyroid carcinomas lacking evidence of progression to poorly differentiated or undifferentiated tumor phenotypes. Clin Cancer Res. 1998;4(2):287-94.

Tang G. siRNA and miRNA: an insight into RISCs. Trends Biochem Sci. 2005;30(2):106-14.

Tang W, David FB, Wilson MM, Barwick BG, Leyland-Jones BR, Bouzyk MM. DNA extraction from formalin-fixed, paraffin-embedded tissue. Cold Spring Harb Protoc. 2009;2009(2):pdb.prot5138.

Tetzlaff MT, Liu A, Xu X, Master SR, Baldwin DA, Tobias JW, et al. Differential expression of miRNAs in papillary thyroid carcinoma compared to multinodular goiter using formalin fixed paraffin embedded tissues. Endocr Pathol. 2007;18(3):163-73.

Thomas GA, Bunnell H, Cook HA, Williams ED, Nerovnya A, Cherstvoy ED, et al. High prevalence of RET/PTC rearrangements in Ukrainian and Belarussian postChernobyl thyroid papillary carcinomas: a strong correlation between RET/PTC3 and the solid-follicular variant. J Clin Endocrinol Metab. 1999;84(11):4232-8.

Todd JR, Scurr LL, Becker TM, Kefford RF, Rizos H. The MAPK pathway functions as a redundant survival signal that reinforces the PI3K cascade in c-Kit mutant melanoma. Oncogene. 2012.

Unger K, Zitzelsberger H, Salvatore G, Santoro M, Bogdanova T, Braselmann H, et al. Heterogeneity in the distribution of RET/PTC rearrangements within individual post-Chernobyl papillary thyroid carcinomas. $J$ Clin Endocrinol Metab. 2004;89(9):4272-9.

Valastyan S, Chang A, Benaich N, Reinhardt F, Weinberg RA. Activation of miR-31 function in already-established metastases elicits metastatic regression. Genes Dev. $2011 ; 25(6): 646-59$.

Vasko V, Saji M, Hardy E, Kruhlak M, Larin A, Savchenko V, et al. Akt activation and localisation correlate with tumour invasion and oncogene expression in thyroid cancer. J Med Genet. 2004;41(3):161-70.

Vasudevan S, Tong Y, Steitz JA. Switching from repression to activation: microRNAs can up-regulate translation. Science. 2007;318(5858):1931-4. 
Venturini L, Battmer K, Castoldi M, Schultheis B, Hochhaus A, Muckenthaler MU, et al. Expression of the miR-17-92 polycistron in chronic myeloid leukemia (CML) CD34+ cells. Blood. 2007;109(10):4399-405.

Viglietto G, Motti ML, Bruni P, Melillo RM, D'Alessio A, Califano D, et al. Cytoplasmic relocalization and inhibition of the cyclin-dependent kinase inhibitor p27(Kip1) by PKB/Akt-mediated phosphorylation in breast cancer. Nat Med. 2002;8(10):1136-44.

Visone R, Russo L, Pallante P, De Martino I, Ferraro A, Leone V, et al. MicroRNAs (miR)-221 and miR-222, both overexpressed in human thyroid papillary carcinomas, regulate p27Kip1 protein levels and cell cycle. Endocr Relat Cancer. 2007;14(3):7918.

Vogelstein B, Kinzler KW. Digital PCR. Proc Natl Acad Sci U S A. 1999;96(16):923641.

Volinia S, Calin GA, Liu CG, Ambs S, Cimmino A, Petrocca F, et al. A microRNA expression signature of human solid tumors defines cancer gene targets. Proc Natl Acad Sci U S A. 2006;103(7):2257-61.

Vriens MR, Moses W, Weng J, Peng M, Griffin A, Bleyer A, et al. Clinical and molecular features of papillary thyroid cancer in adolescents and young adults. Cancer. 2011;117(2):259-67.

Wang CJ, Zhou ZG, Wang L, Yang L, Zhou B, Gu J, et al. Clinicopathological significance of microRNA-31, -143 and -145 expression in colorectal cancer. Dis Markers. 2009;26(1):27-34.

Wang Z, Zhang H, He L, Dong W, Li J, Shan Z, et al. Association between the expression of four upregulated miRNAs and extrathyroidal invasion in papillary thyroid carcinoma. Onco Targets Ther. 2013;6:281-7.

Watanabe R, Hayashi Y, Sassa M, Kikumori T, Imai T, Kiuchi T, et al. Possible involvement of BRAFV600E in altered gene expression in papillary thyroid cancer. Endocr J. 2009;56(3):407-14.

Weber F, Teresi RE, Broelsch CE, Frilling A, Eng C. A limited set of human MicroRNA is deregulated in follicular thyroid carcinoma. J Clin Endocrinol Metab. 2006;91(9):3584-91.

Wellbrock C, Karasarides M, Marais R. The RAF proteins take centre stage. Nat Rev Mol Cell Biol. 2004;5(11):875-85.

Woods K, Thomson JM, Hammond SM. Direct regulation of an oncogenic micro-RNA cluster by E2F transcription factors. J Biol Chem. 2007;282(4):2130-4.

Wu H, Huang M, Cao P, Wang T, Shu Y, Liu P. MiR-135a targets JAK2 and inhibits gastric cancer cell proliferation. Cancer Biol Ther. 2012;13(5):281-8.

Xi Y, Nakajima G, Gavin E, Morris CG, Kudo K, Hayashi K, et al. Systematic analysis of microRNA expression of RNA extracted from fresh frozen and formalin-fixed paraffin-embedded samples. RNA. 2007;13(10):1668-74. 
Xing M, Westra WH, Tufano RP, Cohen Y, Rosenbaum E, Rhoden KJ, et al. BRAF mutation predicts a poorer clinical prognosis for papillary thyroid cancer. $\mathrm{J}$ Clin Endocrinol Metab. 2005;90(12):6373-9.

Xing M. BRAF mutation in papillary thyroid cancer: pathogenic role, molecular bases, and clinical implications. Endocr Rev. 2007;28(7):742-62.

Xing M. BRAF mutation in thyroid cancer. Endocr Relat Cancer. 2005;12(2):245-62.

Xing M. Genetic alterations in the phosphatidylinositol-3 kinase/Akt pathway in thyroid cancer. Thyroid. 2010;20(7):697-706.

Xing M. Molecular pathogenesis and mechanisms of thyroid cancer. Nat Rev Cancer. 2013;13(3):184-99.

Xing M. Recent advances in molecular biology of thyroid cancer and their clinical implications. Otolaryngol Clin North Am. 2008;41(6):1135-46, ix.

Xu X, Quiros RM, Gattuso P, Ain KB, Prinz RA. High prevalence of BRAF gene mutation in papillary thyroid carcinomas and thyroid tumor cell lines. Cancer Res. 2003;63(15):4561-7.

Yamada $\mathrm{Y}$, Hidaka $\mathrm{H}$, Seki $\mathrm{N}$, Yoshino $\mathrm{H}$, Yamasaki $\mathrm{T}$, Itesako $\mathrm{T}$, et al. Tumorsuppressive microRNA-135a inhibits cancer cell proliferation by targeting the c-MYC oncogene in renal cell carcinoma. Cancer Sci. 2013;104(3):304-12.

Yanaihara N, Caplen N, Bowman E, Seike M, Kumamoto K, Yi M, et al. Unique microRNA molecular profiles in lung cancer diagnosis and prognosis. Cancer Cell. 2006;9(3):189-98.

Yekta S, Shih IH, Bartel DP. MicroRNA-directed cleavage of HOXB8 mRNA. Science. 2004;304(5670):594-6.

Yi R, Qin Y, Macara IG, Cullen BR. Exportin-5 mediates the nuclear export of premicroRNAs and short hairpin RNAs. Genes Dev. 2003;17(24):3011-6.

Yip L, Kelly L, Shuai Y, Armstrong MJ, Nikiforov YE, Carty SE, et al. MicroRNA signature distinguishes the degree of aggressiveness of papillary thyroid carcinoma. Ann Surg Oncol. 2011;18(7):2035-41.

Yip L, Nikiforova MN, Carty SE, Yim JH, Stang MT, Tublin MJ, et al. Optimizing surgical treatment of papillary thyroid carcinoma associated with BRAF mutation. Surgery. 2009;146(6):1215-23.

Zeng Y, Yi R, Cullen BR. MicroRNAs and small interfering RNAs can inhibit mRNA expression by similar mechanisms. Proc Natl Acad Sci U S A. 2003;100(17):9779-84.

Zerilli M, Zito G, Martorana A, Pitrone M, Cabibi D, Cappello F, et al. BRAF(V600E) mutation influences hypoxia-inducible factor-1alpha expression levels in papillary thyroid cancer. Mod Pathol. 2010;23(8):1052-60. 
Zhang B, Pan X, Cobb GP, Anderson TA. microRNAs as oncogenes and tumor suppressors. Dev Biol. 2007;302(1):1-12.

Zhang X, Chen J, Radcliffe T, Lebrun DP, Tron VA, Feilotter H. An array-based analysis of microRNA expression comparing matched frozen and formalin-fixed paraffin-embedded human tissue samples. J Mol Diagn. 2008;10(6):513-9.

Zhao $\mathrm{H}$, Hastie T, Whitfield ML, Børresen-Dale AL, Jeffrey SS. Optimization and evaluation of T7 based RNA linear amplification protocols for CDNA microarray analysis. BMC Genomics. 2002;3(1):31.

Zhou W, Li X, Liu F, Xiao Z, He M, Shen S, et al. MiR-135a promotes growth and invasion of colorectal cancer via metastasis suppressor 1 in vitro. Acta Biochim Biophys Sin (Shanghai). 2012;44(10):838-46.

Zhu Z, Ciampi R, Nikiforova MN, Gandhi M, Nikiforov YE. Prevalence of RET/PTC rearrangements in thyroid papillary carcinomas: effects of the detection methods and genetic heterogeneity. J Clin Endocrinol Metab. 2006;91(9):3603-10. 


\title{
APÊNDICE - Produção Científica
}

\section{Resumo apresentado em pôster no "MicroRNA 2012 - International}

\section{Symposium".}

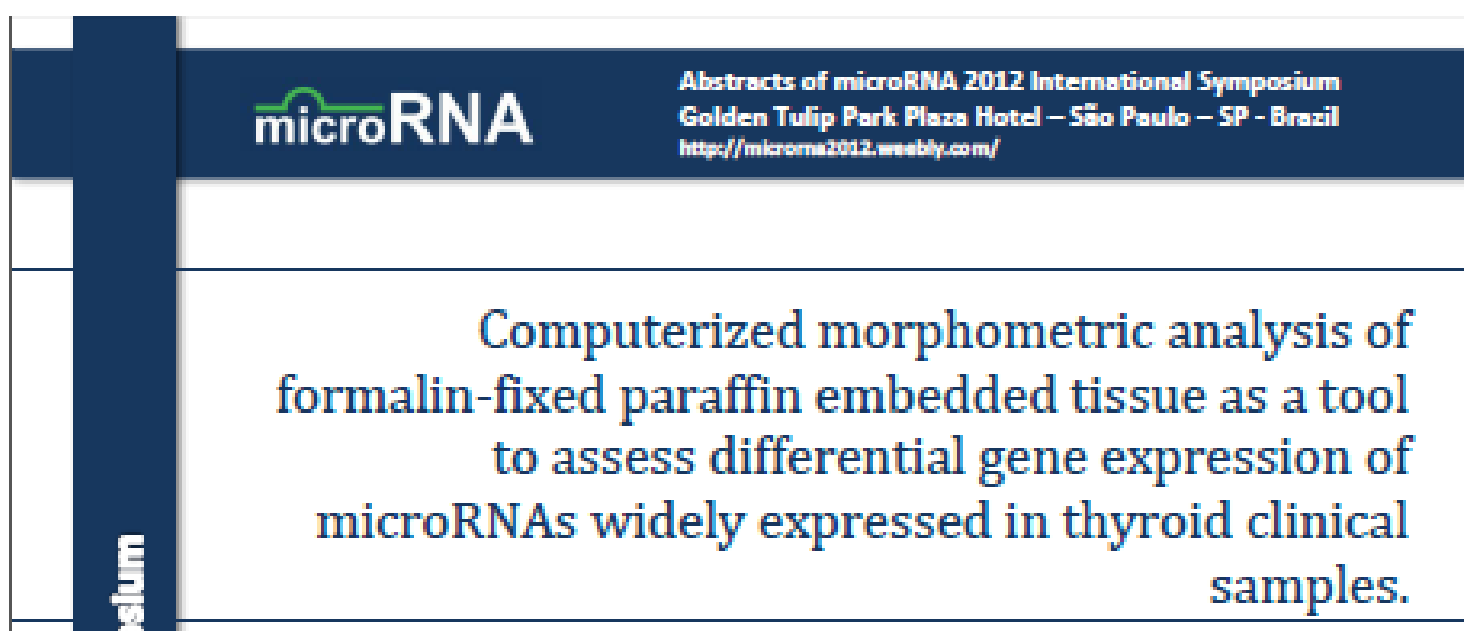

Moulatlet ACB1, Sondermann A23, Andreghetto FM11, Borges F4, Nunes FDs, Brandao $L^{3}$, Severino $P^{1}$.

\begin{abstract}
'Instituto Iaraelita de Ensino o Posquaisa Albert Einstoin, Hospital Israelita Albert Finstein, Sso Pralo, Braril. ${ }^{2}$ Departamento de Cirurgia em Cabeça o Pescoço, Instituto Brarileiro de Controlo do Cancer, SSo Paulo, Branil. 'Departamento de Cirurgia ame Cabeça o Poscoço, Faculdado de Medicina, Univorridado de S3o Paulo, Braril. 'Departamento de Sande Ambiental, Faculdade de Sarude Publica, Universidade de S3o

Paulo, SSo Paulo, Braril. 'Departmento de Estomatologia, Faculdado de Odontologia, Universidade de Sao Paulo, Braril.

provorgainstoin br
\end{abstract}

Papillary thyroid carcinoma (PTC) is the most common malignancy in thyroid tissue, accounting for near $80 \%$ of all thyroid cancers. Despite the generally favorable prognosis and high survival rates of most patients with PTC, some tumors display an aggressive behavior and may progress to the highly aggressive and lethal anaplastic thyroid carcinoma. MicroRNAs are a recently discovered class of small non-coding RNA molecules that take part in essential regulatory networks through targeting of mRNÁs. They are reportedly involved in the pathogenesis of diverse human cancers but information regarding this association in papillary thyroid cancer is sparse. In this stady, we analyzed the expression of miR-146a/b, miR-221 and miR-222, previously associated with clinical and genetic features in this kind of cancer, in formalin-fixed paraffin-embedded thyroid tissue using quantitative real-time polymerase chain reaction. The heterogeneity of embedded-tissues is a major drawback in this approach and was assessed by means of computerized morphometric image analysis. Our results corroborate the potential importance of these microRNAs in papillary thyroid cancer, although gene expression levels in tumor tissue varied from patient to patient and the expression in surrounding tumor-free areas was significant. We highlight the need for carefil interpretation of microRNA expression analysis in formalin-fixed paraffin-embedded tissue for cancer biomarker discovery.

Financial support: Hospital Israelita Albert Einstein, CAPES. 


\title{
2. Resumo apresentado em poster no "Signaling 2010 - Cell Death, Cancer and
}

\author{
The Immune System".
}

\author{
MICRORNA-146B AND IMMUNE RESPONSE: A STUDY USING FORMALIN-FIXED
}

\section{AND PARAFFIN-EMBEDDED PAPILLARY THYROID CÂNCER TISSUE}

Ana Carolina Bernardini Moulatlet1, Adriana Sondermann2, Flávia Maziero Andreghetto1, Renata Machado Soares1, Flávia Caló3, Fábio Daumas Nunes3, Flávio Borges4, Lenine Brandão2, Patricia Severino1

1 Centro de Pesquisa Experimental, Instituto Israelita de Ensino e Pesquisa Albert Einstein, São Paulo, 2 Instituto Brasileiro de Controle do Câncer, São Paulo, 3 Departamento de Estomatologia, Faculdade de Odontologia da Universidade de São Paulo, São Paulo, 4 Departamento de Saúde Ambiental, Faculdade de Saúde Pública da Universidade de São Paulo, São Paulo.

Introduction: Differentiated thyroid cancers, including papillary thyroid carcinoma (PTC), are a useful model with which to examine interactions between cancer and the immune system. Thyroid microcarcinomas are far more common than PTC, suggesting that the immune system might restrain the growth of these microcarcinomas. MicroRNAs represent a new class of endogenous 22-nt noncoding RNA species that regulate the expression of target genes posttranscriptionally. Growing evidence suggests that microRNAs play an important role in immune system function. As one such molecule, miR-146 is frequently upregulated in PTC and seems to affect cytokine signaling and thus the immune response. MiR-146 occurs in two distinct isoforms: miR-146a and miR-146b, which are differently regulated. Another attractive feature of miRNAs is their high conservation in formalin-fixed, paraffin-embedded (FFPE) tissue specimens, allowing informative research in well-annotated archives. Objective: (1) Evaluate miR-146b in PTC versus surgical margins in fresh tumor samples, (2) correlate results in fresh samples with FFPE tissue, and (3) infer miR-146b possible role in immune response through the analysis of its in silico predicted targets. Methodology: Fresh samples from PTC and normal thyroid tissue were obtained from patients undergoing surgical resection. Expression levels of miR-146b obtained from fresh PTC were compared to levels in FFPE samples by means of qPCR. MiR-146b gene targets were selected by current computational approaches to microRNA target prediction. Results and Conclusions: We demonstrate the up-regulation of miR-146b in PTC versus tumorfree surgical margins. There were no significant differences between miR-146b expression levels in fresh PTC and FFPE PTC when these levels were compared to normal thyroid samples. TNF receptor-associated factor 6 (TRAF6), which mediates signaling to members of the TNF receptor and Toll/IL-1 families, is a miR-146 predicted target. Recent reports show that TRAF6 is not just involved in innate immune response, but also plays a role in cell growth and carcinogenesis through an interaction with AKT. We corroborate data on miR-146b as part of the intricate network that fine-tunes immune response.

Financial Support: Instituto Israelita de Ensino e Pesquisa (IEP.PE.08-0125). 